\title{
Publij Ovidij Nazon: Metamorfoze 13-15
}

\author{
Prevedel Joža Lovrenčič
}

Trinajsta knjiga

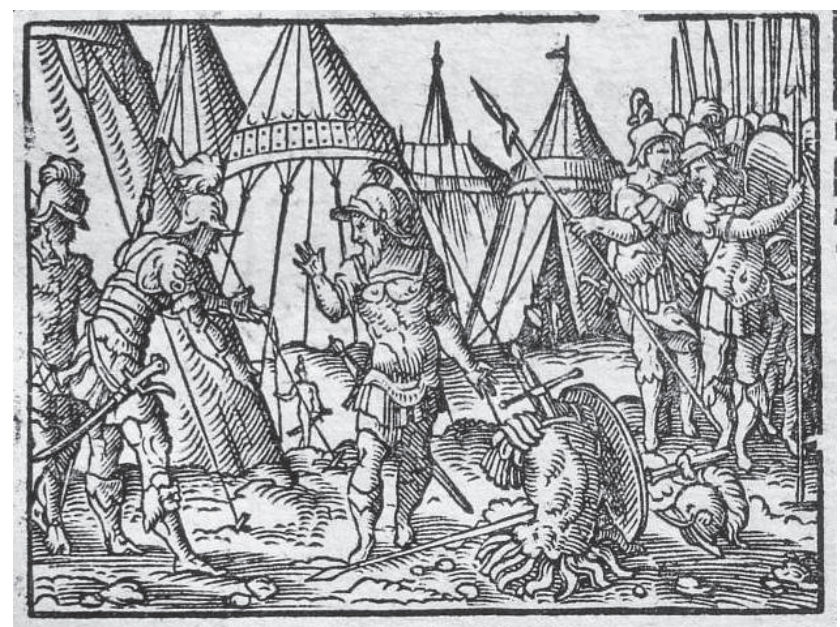

Slika 5: Ulixes et Aiax (13.1-43)

Spor Ajanta in Odiseja za Ahilovo orožje

Ko so se vodje usedli in v krogu so stali vojščaki, vstal je med njimi Ajant, lastnik sedmernega ščita; kakor ni mogel obvladati jeze, se z mrkim pogledom proti sigejski obali obrnil je, proti brodovju, roke razširil in rekel: »O Jupiter, tu pred ladjevjem ženemo pravdo, Uliks pa se upa primerjati z mano! Ni si pomišljal bežati, ko Hektor grozil je s plameni; 
jaz sem vzdržal med njimi, pregnal sem jih proč od brodovja.

Varneje, res, bojevati je s kom se z besed izmišljijo,

kakor boriti se z roko. Nespreten sem jaz v govorjenju,

on v bojevanju. In kolikor jaz na krvavem torišču

v boju pomenim, pomeni on sam kot spreten govornik.

Mislim, Pelazgi, da mojih vam del ni omenjati treba,

saj ste jih videli. Raje Uliks naj pove nam o svojih,

ki jih brez prič je izvršil in zanje edinole noč ve.

Res, da zahtevam veliko nagrado, a čast ji odvzema

tekmec; Ajant se ne bo ponašal, da kaj je dosegel,

najsi še takšna bo stvar, če to še Uliks si je upal.

Sam je danes že s tem dobil nagrado v tej tekmi,

tudi če zmagam, da $\mathrm{z}$ mano lahko se je zanjo pomeril.

Jaz pa, če moje junaštvo se komu bo zdelo dvomljivo, tudi po rodu mogočen sem, sin Telamona, ki nekdaj s Herkulom silnim in hrabrim že mesto trojansko zavzel je, z ladjo nato pagasejsko na kolhijski breg je prijadral.

Oče njegov je Ajak, ki sodi molčečim, kjer Sizif, Ajolov sin, pod bremenom skaline pretežke krivi se. Jupiter, vzvišeni bog, za svojega sina priznava Ajaka; torej Ajant je po Jupitru tretji po rodu. Vendar, Ahajci, z rodovnikom ne bi se kitil v tej tekmi, če bi ne bil mi skupen s pokojnikom, s silnim Ahilom.

Bil je bratranec in stvar bratrančevo hočem. Kaj neki Sizifov zdaj potomec, enak mu v zvijači in laži, vpletaš se s tujim imenom med nas, med rod Ajakidov?

To, da pred njim sem na vojsko odšel, ne da kdo bi me silil, zdaj mi je v škodo v tej tekmi? In vrednejši on je nemara, ker je kot zadnji prijel za orožje, se blaznega delal, vojski se spretno ogibal, dokler ni modrejši od njega, Navplijev sin, razkrinkal plašljive prevare in sebi v škodo odgnal ga na vojsko, čeprav se ji ta je izmikal? Zdaj pa dobi naj najboljše orožje, ko zgrabiti prej ni hotel nobenega, jaz pa ob čast in bratrančev naj dar bom, jaz, ki takoj sem prišel in planil že v prvo nevarnost?

O da resnična njegova bi blaznost bila, da takrat bi vsaj ji verjeli, da ne bi šel z nami pod frigijske stene, zla vzpodbujalec! Na Lemnu ne bil bi tedaj izpostavljen česar smo tudi mi krivi - ti, sin Pojantov, ki skrivaš v gozdnih votlinah se zdaj, se smiliš, kot pravi se, skalam, 
zraven pa sinu Laerta želiš, kar mu gre po pravici, česar, če kje so bogovi, ne kličeš zaman mu nad glavo. On, ki prisegel je $\mathrm{z}$ nami in v boj šel kot grški poveljnik, on, ki mu Herkul je puščice dal, da jih zdaj uporablja, tam od bolezni in lakote zdelan oblači in hrani zdaj se s pticami; puščice, mišljene Troji v pogubo, proži v perjad, ki lovi jo. A vendar je tam vsaj preživel, živ je, ker ni Uliksa na poti do semkaj pospremil. Da, Palamed nesrečni bi rajši, da sam zaostal bi, še bi živel, če pa vmes bi umrl, odšel bi nedolžen; ni mu pozabil Uliks, da njegovo norost je razkrinkal, šel mu podtaknit je laž, da izdaja Danajce, in lažno krivdo dokazal je z zlatom, ki sam ga prej je zakopal. $S$ tem jemal je bojne moči Ahajcem, s pregnanstvom ali z umorom. Tako se bori in tako se je bati treba Uliksa. Čeprav je v govoru boljši kot Nestor, me ne prepriča, da nič ni zakrivil takrat, ko je pustil Nestorja; ta zaostal je, ker konj je bil ranjen, on sam pa truden od svoje starosti. Tovarišu nič ni pomagal, ta ga zaman je rotil. Da tega si nisem izmislil, ve Tidejev otrok Diomed, ki večkrat je klical, hkrati pa grajal plašljivega druga in beg mu očital. Zgornji bogovi pravično vsa dela človeška motrijo.

Kdor ne pomaga, pogreša pomoč, in kakor zapustil koga je kdo, zapuščen bo: tako se že sam je obsodil. Tale je klical tovariše, šel sem in videl, kako se tresel je v strahu, ves bled, ko kar trepetal je pred smrtjo. S ščitom sem svojim velikim ležečega kril in ga branil, rešil sem s tem bojazljivca, kar ni mi v nikakršno slavo. Zdaj bi se rad boril? Vrniva na tisto se mesto: skliči sovražnika spet in ranjen in v svoji bojazni skrij se pod ščit in znova $\mathrm{z}$ menoj pod njim se pomeri! No, ko sem enkrat ga rešil, ga rana ni nič več motila, brž je pobegnil, čeprav pred tem še stati ni mogel.

Ko pa nastopil je Hektor in v boj šel $\mathrm{z}$ bogovi ob strani, kjer je udaril, Uliks, tedaj ni le tebe prestrašil, temveč še hrabre junake, ker takšen preplah je povzročil. Jaz pa, ko v boju krvavem uspešen je vzklikal veselo, s kamnom sem težkim od daleč zadel ga, da vznak se je zvrnil. Ko je izzival na boj, edini sem z njim se spopadel: vi ste, Ahajci, želeli mi srečo - in vaše molitve res so zalegle. Če kdo po uspehu bi tega spopada 
vprašal, lahko bi izvedel, da ni me Hektor premagal.

$\mathrm{Z}$ mečem in ognjem in Jupitrom, glej, so pridrli Trojanci

k ladjam danajskim. Le kje zgovorni Uliks se je skrival?

Jaz pa s svojimi prsmi zaščitil sem ladje, vseh tisoč, upanje vaše vrnitve. Zdaj zanje orožje mi dajte!

Naj resnico povem, če smem: orožje dobilo

večje priznanje kot jaz bo, ker moje bo slave deležno:

išče orožje Ajanta, Ajant ne išče orožja.

S tem Itačan naj primerja plašljivega Dolona, Resa,

Palas izmaknjeno, Helena ujetega, Priamu sina.

Nič ni opravil podnevi in nič ne brez Diomeda.

$\mathrm{Da}$, če že hočete dati orožje za drobna junaštva, dajte na dela ga dva - in večji naj gre Diomedu.

Kaj naj z njim Itačan? Saj skrit in brez bojne oprave vselej bori se in vara sovraga brezskrbnega zvito.

Samega zlatega šlema blesteči sijaj že izdal bo, kje je zaseda in hkrati odkril bo pod šlemom skrivača.

Šibka Dulihijca glava nikoli nositi ne more tolikšne teže čelade Ahilove, niti držati roka, nevajena boja, ne s Pelija težkega kopja.

Ščit, ki na njem je ves svet vkovan, tak ščit bi pa tudi

nič ne pristajal boječi levici, rojeni za krajo.

Kaj boš, podlež, s tem darom? Pod njim boš kvečjemu klecal!

Če ti pomotoma ljudstvo ahajsko bo dalo orožje,

z njim ne boš strašil sovražnika, ta ti ga vzame.

Beg, ki v edinem posekaš prav vse, boječnež največji, zate postal bo težaven, ko tolikšno breme boš nosil.

K vsemu dodaj, da tvoj ščit, s katerim si redko bil v boju, cel, nedotaknjen je - moj pa, ki z njim sem odbijal udarce, tisočkrat ves je prebit in novega res potrebujem.

Končno pa, kaj je še treba besed? Pokažimo z dejanjem!

Dajte, orožje junaka pošljite v sovražnikov sredo: ponj ukažite oditi in kdor ga prinese, bo zmagal!«

Sin Telamonov končal je. Po zadnjih njegovih besedah hrup se je širil med moštvom, dokler ni potomec Laertov dvignil se, nekaj trenutkov še v tla strmel je s pogledom, potlej v veljake oči je privzdignil in usta odprl pričakovani besedi, da spretno mu tekel je govor: 
»Res, če bi moja in vaša zadoščala želja, Pelazgi, ne bi ugibali zdaj, se prepirali, kdo naj bo dedič: mi bi, Ahil, te imeli, in ti imel bi orožje!

Ker pa ga kruta usoda je meni in vam ugrabila, - z roko je tu obrisal oči, kot brisal bi solze kdo naj pravičneje kaj bi dobil po junaškem Ahilu, kakor pa ta, ki Danajcem je sam Ahila pridobil? Temu naj nič ne koristi, da bebec se zdi in zares je, meni pa zdaj naj ne škodi razum, ki vam vedno, Ahajci, v prid je bil. Moja zgovornost, pa naj bo kakršnakoli, - zdaj se pač zame zavzema, a večkrat se tudi za vas je noče vam nič; a lastnih vrlin nihče ne zanika.

Rod, pradedje in vse, česar nismo napravili sami, tega za svoje ne moremo šteti. Ajant je poudaril to, da je Jupitrov pravnuk. $V$ naši rodbini je tudi Jupiter prvi in jaz sem v enakem kolenu od njega. Oče je meni Laert, a njemu Arkesij in temu Jupiter - nihče od njih ni obsojenec, nihče pregnanec. Zraven po materi smo s Kilenijcem v plemiškem rodu, torej po rodu v obeh je roditeljih mojih božanstvo. Vendar pa jaz ne zahtevam orožja zato, ker po strani materini sem bolj plemenit, in ne, ker ni oče bratomorilec. Rešite samo po zaslugah zadevo! To, da bila Telamon in Pelej sta si brata, v zaslugo to naj Ajantu ne šteje, saj tu ne gre za sorodstvo; hrabrost in slava, le to naj odloča pri bojni opravi! Če pa najbližje sorodstvo in dedič resnični se išče, oče Ahilov Pelej je - in Pir otrok je Ahilov. Kje je Ajant? Na Skir ali v Ftijo nesite orožje! Tevker pa tudi ni manj kot tale bratranec Ahilu no, je zahteval orožje? In vi, bi zahtevi ustregli? Torej - ker v sporu sedaj gre zgolj za opravljeno delo, jaz sem opravil ga več, kakor zdaj povedati zmorem s svojo besedo; a naj se držim dogodkov po vrsti.

Mati njegova Nerejka, ki vedela je, da bo padel, sina bila preoblekla je; s to preobleko zvijačno potlej je vse prevarala, njega, Ajanta, med njimi. Jaz pa med žensko blago sem pomešal orožje, da z njim bi moško vzbudil zavest. Ko ni še odložil mladenič ženske obleke in ščit je in kopje le v roki podržal, rekel sem: »Sin boginjin, zdaj čaka te Pergam, ki pade, 
kaj obotavljaš se, fant, da porušil mogočno bi Trojo? «

Roko nato sem mu dal in poslal na junaštva junaka.

Torej njegova junaštva so moja. Jaz Telefa v boju s kopjem sem ranil in ranjenega, ko je prosil, ozdravil. Tebe so padle po moji zaslugi; in Lesbos in Tened, Hriso in Kilo, ti mesti Apolonovi, da, še Skir sem, vedite, jaz zavzel. V tem smislu je moja desnica lirneško mesto omajala, vsega do tal ga podrla. Jaz, da o drugem molčim, sem junaka vam dal, ki je mogel Hektorju vzeti življenje - sam Hektor po meni je padel! Zdaj za tisto orožje, ki z njim odkril sem Ahila, tole zahtevam: kar živemu dal sem, naj mrtvi mi vrne.

V dneh, ko enega žalost Danajci so vsi občutili, tisoč je ladij, pripravljenih v Avlidi tam pri Evboji, dolgo čakalo brez vetra; če kdaj je zapihal, brodovju pihal nasproti je. Kruta prerokba tedaj je velela, naj Agamemnon Diani užaljeni hčerko žrtvuje. Oče se temu upiral je, jezen celo na bogove, saj še kot kralj je bil oče. Jaz blago naravo očeta s svojo besedo za obči sem blagor na koncu pridobil, kar šele zdaj priznavam, Atrid pa naj to odpusti mi. Težka bila je zadeva, ko bil je sodnik nenaklonjen, vendar ganila korist ga je ljudstva in brat in pa žezlo, njemu zaupano; slavo na koncu s krvjo je odtehtal. Mene poslali so k materi. Ni šlo z besedo, z zvijačo slednjič uspel sem. Če k njej bi tedaj odšel Telamonec, jadra bi naša še danes ostala brez pravega vetra.

Jaz sem kot drzni poslanec odšel tudi v ilijsko mesto, v Trojo visoko prišel sem in vstopil sem v zbornico njeno, polna tedaj še bila je junakov. Pogumno opravil vse sem, kar prej naročila bila mi je Grčija cela, Parisa tožil in Heleno s plenom nazaj sem zahteval.

Priam se vdal je, Antenor je s Priamom hkrati soglašal, Paris in bratje in vsi, ki so zraven bili pri tatvini, komaj so roke obvladali; to, Menelaj, ti je znano, ta je bil prvi od dni, ko s tabo sem tvegal nevarnost.

Dolgo bi vzelo, našteti, kaj vse sem z nasvetom in z roko sam koristnega storil v obdobju te vojne predolge. Dolgo po prvih spopadih sovražnik za mestnim obzidjem raje ostal je in vzel nam priložnost, da z njim bi odprto 
kdaj se spopadli; ta v letu desetem se spet je vrnila.

Kaj si ti delal med tem, sposoben za nič, le za bitko?

$\mathrm{V}$ kakšno korist si nam bil? A če vprašal po mojem bi delu:

jarke krepil sem z nasipi, pripravljal zasede sovragu,

svoje rojake učil, prenašati voljno tegobe

dolgega boja; jim kazal, kako se je treba braniti,

najti orožje, in, kamor korist je velela, tja šel sem.

Potlej sam kralj je, opomnjen po Jupitru v sanjah varljivih, hotel, da naj bi na lepem prenehali z bojem začetim;

on se lahko sklicuje, da Jupiter to je ukazal.

Kaj pa Ajant, je bil proti? Je hotel, da zruši se Pergam,

naj se bori, kdor se more? Zakaj ni zadržal vojakov,

ko so hoteli oditi? Zakaj ni še sam vzel orožja, množici v zgled omahljivi? Saj vendar prehud za bahača to ne bil bi izziv - a je raje pobegnil. Ko šel si stran in si jadra sramotno pripravljal, sem videl in sram je gledati to me bilo. »Kaj delate, kakšna vas blaznost žene, tovariši, « rekel sem brž, »da zapuščate Trojo? Kaj odnašate v letu desetem domov? Le sramoto? « $\mathrm{S}$ takšno in $\mathrm{z}$ drugo besedo - bridkost mi je dala zgovornost umikajoče že z ladij na begu nazaj sem privabil. Potlej prestrašene sklical Atrid je tovariše k zboru, a Telamonec ni niti tedaj si ziniti drznil, dasi Tersit nastopiti si upal je s smelo besedo zoper vse kralje, za kar pa sem jaz mu pošteno posvetil. Sam sem vstal in spodbudil boječneže zoper sovraga, s svojo besedo zgubljeni pogum sem tovarišem vrnil. $\mathrm{Da}$, če Ajant je odslej kaj junaškega kje še napravil, moje je, moja zasluga; bežečega jaz sem ustavil.

Končno pa, kdo med Danajci te hvali, kdo išče za družbo? Svojih junaštev, glej, skupaj z menoj Tidid se loteva, hvali me, veš, in Uliksu, tovarišu, vedno zaupa.

To že nekaj pomeni, med toliko tisoči Grkov mene izbral Diomed je, pa ne da bi žreb ga prisilil. Šel sem, preziral nevarnost noči in sovraga, ubil sem Frigijca Dolona, isto takrat je poskušal kot midva, vendar sem prej ga še v to prisilil, da vse mi izdal je: zvedel tako sem, kaj Troja zahrbtna na skrivnem pripravlja. Vse sem dognal in opravil sem svoje izvidniško delo, zlahka tedaj bi se vrnil nazaj po obljubljeno hvalo. Nisem bil s tem zadovoljen, odpravil sem v šotor se k Resu, 
v taboru njihovem njega in spremstvo njegovo usmrtil: v vozu zajetem se vrnil sem, kar sem želel, sem dosegel, prav kot nekdo, ki je zmagal, bi rekel, v veselem triumfu. Kdor mi odreče orožje človeka, ki konje njegove v noči je zase sovražnik iskal, je bolj skop od Ajanta. Kaj naj omenjam Sarpédona Likijca četo, ki z mečem svojim pobil sem jo? V boju krvavem ubil sem nato še Kojrana, Ifitu sina, Alástorja in pa Alkandra, Hromija, Halija in še Noémona in pa Pritana, Hersidamánta, Toóna in Háropa, vse sem potolkel, z njimi Enóma, ki kruta usoda za njim je hodila, dalje še druge, manj slavne, ki tam pod trojanskim obzidjem padli pod mojo so roko. Rojaki, jaz tudi imam jih rane, po mestu že častne; to niso le prazne besede, glejte jih!« Z roko nato je odmaknil obleko in rekel: »Prsi te vedno borile pogumno za vaš so se blagor, sin Telamonov pa v toliko letih izgubil ni niti kaplje krvi za soborce, njegovo telo je brez rane!

Kaj naj koristi bahanje, da s svojim orožjem boril se zoper Trojance in Jupitra je za brodovje Pelazgov? Res je, boril se je: nimam navade, da zlobno tajil bi dela zaslužna. A skupnih naporov si sam ne prisvajaj! Slave bi tudi vsem vam nekoliko zlahka privoščil. Aktorjev vnuk je, v opravi Ahilovi varen, Trojance spodil od ladij, sicer bi obenem $\mathrm{z}$ branilcem zgorele. Zdaj se baha, da sam se je s Hektorjem upal boriti spet je pri tem pozabil na kralje, glavarje in mene! Bil je deveti po vrsti in z žrebom določen v to službo. Kakšen pa končni izid je bil vajine borbe, prehrabri? Hektor nobene ni rane takrat iz spopada odnesel.

Oh, kako mi težko je, če tistega časa bridkosti

spomnim se, dne, ko je padel Ahil, zaslomba vseh Grkov, mrtev! Ne solze, ne žalost tedaj in ne strah zadržali niso me več, da bi silnega trupla ne vzel in prinesel. $\mathrm{Da}$, na teh plečih, zares, na teh plečih Ahilovo truplo nesel sem hkrati z orožjem, ki zdaj bi ga samo rad nosil. Moč sem svojo ohranil, vzdržala bi tolikšno breme, zraven srce sem ohranil, hvaležno za vaše priznanje. Sinja se mati seveda zato je gnala za sina, vneta, da dar božanski, to delo umetniško, nosil kdaj bi vojščak surov, brez trohe razumnosti v prsih? 
Kje razpoznal naj bi takle na ščit upodobljeno morje, zemljo, visoko nebo in na njem še vse zvezde, Plejade, dežne Hijade, Medveda, ki v morju se nikdar ne zmoči, mesti različni in zraven še meč, ki ga Orion nosi? Rad bi dobil orožje, čeprav ga še sam ne razume.

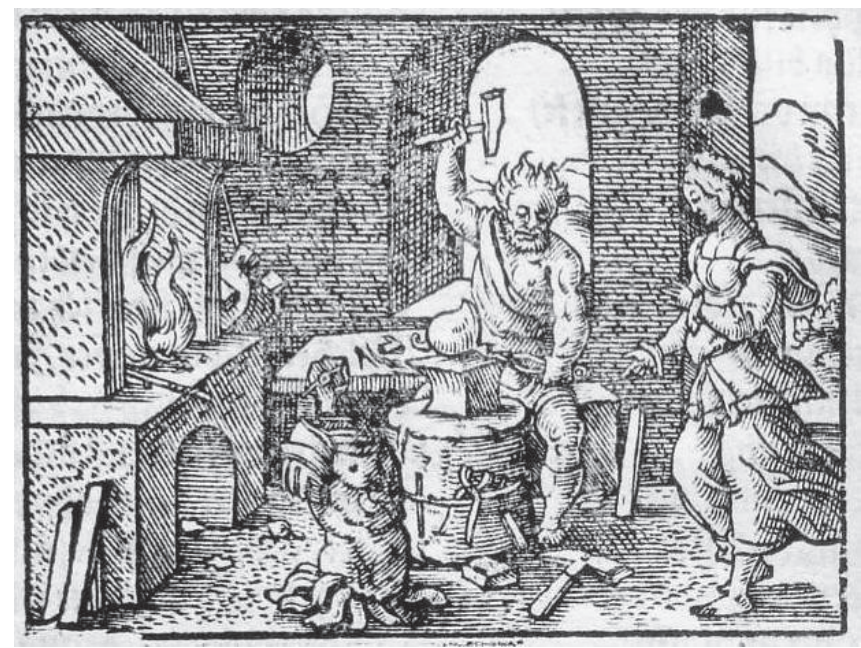

Slika 6: Arma Achillis (13.286-295)

Kar pa se tiče trditve, da trdi vojaški sem službi sam se umikal, da pozno prišel sem zraven $\mathrm{k}$ pohodu res ne ve, da s tem junaškega blati Ahila?

Če je zločin pretvarjanje, to sva oba zagrešila, če pa je krivda zamuda - jaz prej prišel sem od njega.

Mene ljubeča je žena držala, Ahila pa mati;

$\mathrm{z}$ njima sva prve se dni pomudila, vse druge pa $\mathrm{z}$ vami. Nič ne bojim se, čeprav se braniti ne morem, ko skupno s takšnim junakom sem kriv: a um je Uliksov Ahilu vendarle kos bil nekoč; Ajantov težko bo Uliksu.

Nič se mu torej ne čudim, ko s svojim nemarnim jezikom siplje čez mene klevete, ko vas grdo obmetava. Zdaj naj bo podlo, da jaz sem po krivem dolžil Palameda, to, da ste vi obsodili ga, to pa za vas naj bo častno? Vem pa, da Navpljev sin ni očitne in tolikšne krivde mogel zanikati, sami ste slišali zanjo in sami videli težo zlata, podkupnine, odkrite pred vami. 
Prav tako malo sem kriv, da tam na Vulkanovem Lemnu sin Pojantov je zdaj. Ukrep svoj sami branite, saj je bil sklenjen soglasno. Seveda, ne rečem, da nisem jaz svetoval, naj odtegne naporu poti se in boja, vzame si nekaj počitka, da z njim bolečin bi se rešil. Mož je poslušal - in zdaj živi. Nasvet je bil dober, tudi koristil je, dasi dovolj je že dobro želeti.

Zdaj ga zahtevajo vidci nazaj, da Pergam bo padel; mene ne silite ponj, Telamonec naj rajši kar sam gre! $\mathrm{S}$ svojo besedo junaka, besnečega $\mathrm{v}$ boli in $\mathrm{v}$ jezi, brž pomiril bo in, zvit, ga s pretkanostjo svojo pripeljal. Prej Simoent bo tekel nazaj in brez listja bo Ida, prej še sama Ahaja bo Troji pomoč ponudila, preden bi kaj koristiti mogla Danajcem razsodnost bebca Ajanta, če jaz bi z razumom vam svojim umanjkal. Tudi če zdaj sovražiš tovariše, kralja in mene, ti Filoktet brezsrčni, če kolneš, če meni nenehno glavo preklinjaš, želeč, da bi v roke dobil me in kri mi $\mathrm{v}$ besu prelil in jo pil; želim nama isto priložnost, sebi, da tebe dobim, in tebi, da prideš do mene. Vendar bom k tebi odšel in te skušal s seboj pripeljati: sreča pri tem naj pomaga, da svojim lahko bom pridobil puščice tvoje, tako kot ujel sem dardanskega vidca, prav kot razbral sem izrek bogov in trojansko usodo, prav kot Minerve sem frigijske kip iz svetišča odnesel sredi sovražnikov! Naj se Ajant res z mano primerja? Kip je pogoj Usode, brez njega ne pridemo v Trojo. Kje je zdaj hrabri Ajant? Kje zdaj so silne besede slavnega borca? Zakaj si se bal? Zakaj si Uliks je upal ob vseh zasedah med stražami iti ponoči, sam med bridkimi meči prebiti se v mesto Trojancev, $\mathrm{v}$ grad najvišji vstopiti in tam ugrabiti boginjo v njenem svetišču in skozi sovražnike sem jo prinesti? $\mathrm{Da}$, ko bi tega ne storil, sedaj bi sin Telamonov ščit sedmerni iz kož volovskih prenašal brez haska. Tiste noči sem zmagal nad Trojo in Pergam osvojil, to sem vse opravil, ko zmago naredil sem možno. 


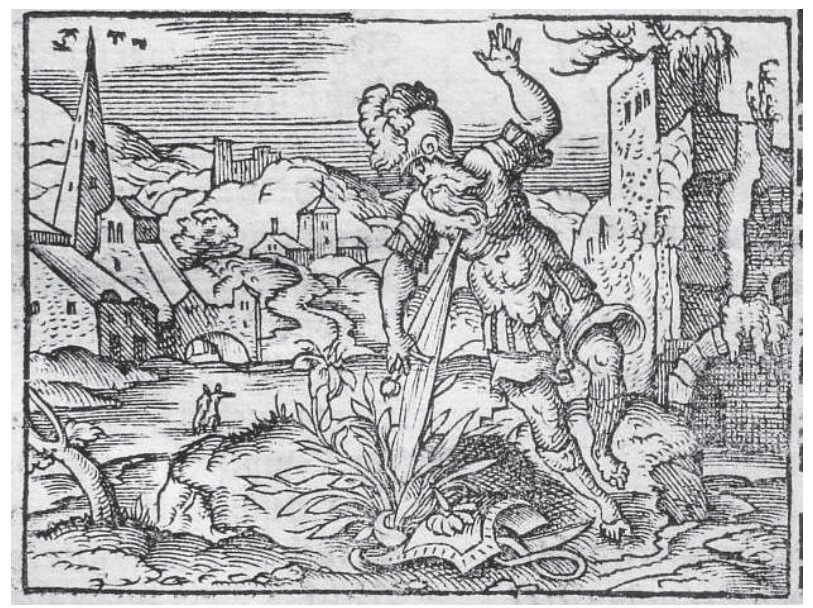

Slika 7: Aiax sibi mortem dat (13.284-399)

Nehaj, nikar ne očitaj z očmi in s svojim mrmranjem meni sedaj Diomeda! Del slave gre kajpada njemu. Tudi ti sam takrat, ko ščitil si naše brodovje, nisi bil sam, bilo vas je mnogo, $\mathrm{z}$ menoj pa le eden. Ta bi tudi orožje zahteval, a ve, da bojevnik manj je kot modrec in ve, da tak dar ne pristaja desnici neukrotljivi. Lahko bi bolj zmerni Ajant ga zahteval, močni Evrípil in slavnega sin Andremóna in tudi Idomenej in njegov rojak Merión in nazadnje brat bi Atrida starejšega zlahka ga zase zahteval: hrabri so vsi in nihče zaostajal ni v boju za mano, pač pa v modrosti so. Tvoja desnica za boj je sposobna, duh pa tvoj potrebuje, da jaz ga usmerjam in vodim. Ti uporabljaš moči tjavdan, jaz smiselno delam; ti bojevati se moreš, z menoj pa Atrid ti določa čas bojevanja. Ti drugim s telesno močjo le koristiš, jaz pa z razumom. Za kolikor tisti, ki ladjo krmari, tiste pri veslih prekaša, in kolikor ve vojskovodja več kot navaden vojščak, za toliko jaz te prekašam: duh je več kakor moč; prav v njem je vsa prožna živahnost.

Vi pa, veljaki, mi dajte nagrado za mojo čuječnost, dajte za toliko let, ki v skrbeh sem za vas jih preživel, častno nagrado kot dolžno priznanje za moje zasluge! Boj gre h koncu, odstranil sem vse usodne zapreke, Pergam visoki dejansko zavzel, ko sem to omogočil. Torej pri upanju skupnem, pri mestu Trojancev, ki pade, 
prosim vas zdaj, pri bogovih, ki vzel sem jih vojski sovražni, dalje pri vsem, če je kaj še z modrostjo napraviti treba, da, če kaj pred pogubo je $\mathrm{z}$ drznostjo treba rešiti, vam pa se zdi, da še kaj za konec je Troje potrebno, mislite name! Če nočete meni predati orožja, dajte ga temu!« In kip je usodne Minerve pokazal.

Zbor veljakov je ganjen odločil. Kaj zmore zgovornost, to je izpričal uspeh: orožje so dali Uliksu.

Toda Ajant, ki pred Hektorjem, Jupitrom, mečem in ognjem sam je tolikrat vzdržal, ni mogel vzdržati pred jezo: žalost premagala borca je nepremagljivega. Zgrabil meč je in rekel: »Vsaj ta je moj! Uliks, bi še tega? Zdaj ga porabil bom zase. Kot večkrat je meč oškropila frigijska kri poprej, z gospodarjevo zdaj oškropljen bo drug Ajanta ne bo, edino Ajant ga premaga!« To je dejal in v prsi, ki prvo dobile so rano, kjer so ranljive bile, smrtonosni svoj meč je zasadil. Roke globoko zabodenega niso mogle izvleči, sama ga kri je izrinila. Zemlja, s krvjo prepojena, sredi zelenja pognala pri priči škrlatnordeč cvet je, tak kot pri Ojbala sinu nekoč, Hijacintu, iz rane. Črki na lističih srednjih sta tam za moža in junaka hkrati v oznako: pri tem kot ime, pri onem kot tožba.

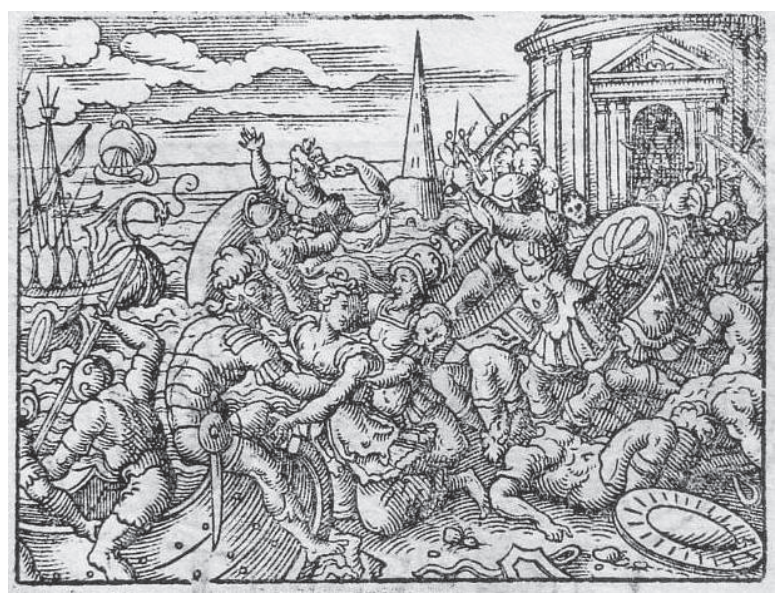

Slika 8: Graeci Hecubam raptant (13.399-428) 
Padec Troje

Potlej na otok, nekoč Hipsipilin, še prej pa Toantov, znan po ženskem pobijanju mož, je odšel zmagovalec, 400 da bi od tamkaj prinesel tirintsko orožje - puščice. Ko jih nato z gospodarjem je vred do Grkov pripeljal, dolga se vojna naposled je vendar približala koncu. Padla je Troja in Priam je padel, a žena njegova vso je, nesrečnica, svojo človeškost bila izgubila z lajanjem strašnim in čudnim odslej je polnila ozračje, kjer Helespont se dolgoraztegnjeni zoži v ožino. Ilion gorel je, ogenj še vedno ni nič kaj pojemal, Jupitrov sveti oltar je vpijal ubitega kralja Priama kri, svečenica Kasandra je k Fojbu na nebu dvigala roke, ko stran so jo vlekli za njene pramene. Dokler so mogle, dardanske so matere kipe domačih svojih božanstev objemale, $v$ templjih gorečih ostale Grki sovražni pa plen ob zmagi so gnali pred sabo. Astianakta so vrgli z obzidja, od koder je večkrat gledal očeta, ki mati mu tam ga je spodaj kazala, ko se je zanj bojeval in dedno kraljestvo mu branil. Sever že klical na pot je, v ugodnih vetrovih zvenel je $\mathrm{v}$ jadrih frfot plahutanja, krmar pa izrabil je veter. "Zbogom zdaj Troja, ženo nas, « Trojanke so vpile in zemljo svojo poljubljale, hiše domače zapuščale v dimu. Zadnja stopila na ladjo Hekaba je, bedna prikazen; prej je bila med grobovi sinov, kjer je svoje gomile božala z roko, kosti je poljubljala; že so jo vlekle roke dulihijske proč. In edino, kar smela je vzeti, Hektorjev bil je pepel, ki s seboj ga je v nedrih odnesla, tam na gomili njegovi kot revno posmrtno je žrtev svoje lase osivele in solze obilne pustila.

\section{Žrtvovanje Poliksene}

Frigiji tam, kjer je Troja bila, je nasproti dežela, kjer so živeli Bistonci in v njej Polimestor imel je dvorec sijajen. In njemu skrivaj te, Polidor, zaupal oče je, v želji, da bil bi daleč od frigijskih bojev. Dobro je mislil, pri tem pa je žal še veliko bogastvo s sinom poslal - in to je nagnilo skopuha k zločinu. 
Kralj brezbožni, Tračan, ko je Frigijcem sreča propadla, meč je zagrabil in vrat varovancu okrutno presekal, potlej pa, kakor da s truplom zločin bi mogel prikriti, mrtvega $\mathrm{z}$ neke pečine je vrgel v valovje tam spodaj. -

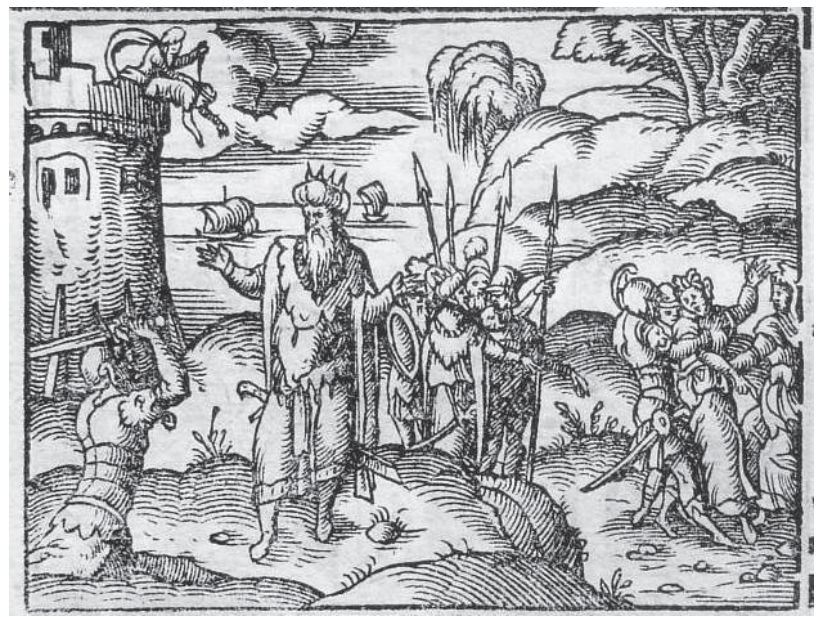

Slika 9: Mors Polydori (13.429-438)

K traški obali privezal Atrid je brodovje, da morje spet bi mirno postalo, in čakal ugodnejši veter.

Tu se nenadno iz zemlje razklane Ahil je prikazal, velik tako, kot v življenju je svojem bil velik, neznanski, takšen v obraz, kakor bil je tedaj, ko jezen grozil je, ko se je $\mathrm{z}$ mečem zavistnim zagnal v Agamemnona besen. »Odpotovali ste, ne da bi mislili name, Ahajci? Zdaj z menoj pokopano je tudi že moje junaštvo? Dajte, nikar naj brez počastitve moj grob ne ostane, mane Ahila naj žrtev miri; želim Polikseno!« To je dejal. Poslušali tovariši senco so kruto, materi vzeli so hčer, ki edina je zanjo skrbela.

Hrabro nesrečno mladenko, ki več je bila kot le ženska, h grobu peljali so, žrtev, namenjeno strašni grmadi. Ko k žrtveniku okrutnemu skupaj prišli so, spoznala brž je, kdo bo zdaj žrtvovan, in samozavestno, ko Neoptolema videla $\mathrm{z}$ mečem je $\mathrm{v}$ roki, kako je svoje poglede upiral naravnost v obraz ji, dejala: "Nič ne odlašaj, kar hitro prelij mi kri plemenito, tukajle v vrat ali v prsi svoj meč mi globoko zabodi!« Vrat si in prsi je hkrati razgalila, njim pa dejala: »Mislite, da Poliksena hotela bi komu služiti? 
Dvomim, da moja bo žrtev lahko pomirila božanstvo!

Rada bi le, da materi smrt bi mojo prikrili.

Mati mi kvari in manjša veselje ob smrti. Ne joči, mati, nad tem, da umiram, skrbi naj te to, da si živa! Vi pa, prosim vas zdaj, odstranite se, rada svobodna šla bi k manom čez Stiks; pri tem pa moška naj roka moje deviško telo pusti. Prijetnejša žrtev tistemu moja svobodna bo kri, naj bil bi kdorkoli, kogar naj to pomiri. Če moje vas zadnje besede ganejo, Priama kralja vas hči, ne ujetnica, prosi materi brez odkupnine na koncu me mrtvo vrnite. Z zlatom si bridke pravice pogreba ne more plačati, dajte, naj plača s solzami, kot prej plačevala je z zlatom." To je dejala, brez solz; a množica ni zadržala solz ob teh besedah in sam svečenik je prisiljen prsi odkrite prebodel, ko vanje svoj meč je porinil. Njena kolena so klecnila, zgrudi dekle se na zemljo, vendar do zadnjega diha pogumen obraz je imela. Tudi tedaj, ko je padla, skrbno si telo je zakrila; v smrti je s tem ohranila si čistost in z njo sramežljivost.

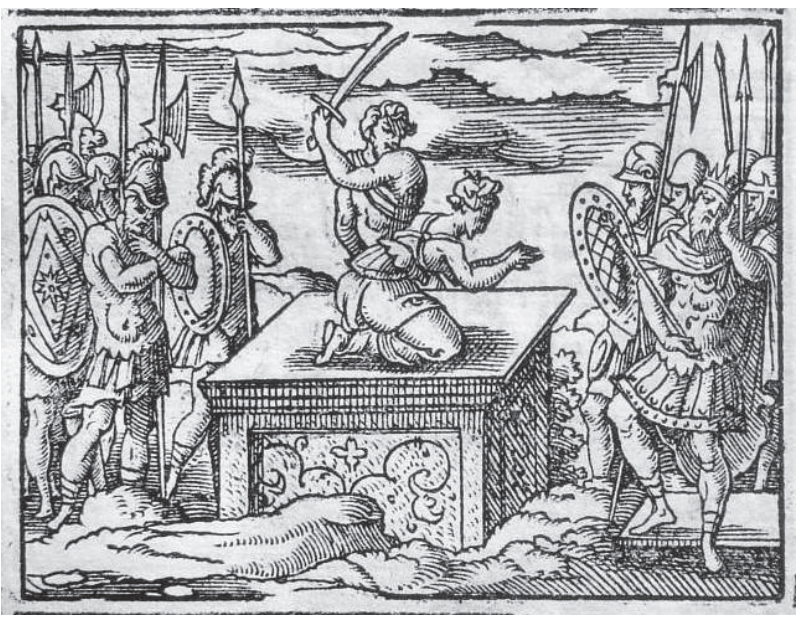

Slika 10: Polyxena interficitur (13.440-480)

\section{Hekabina žalost}

Žene trojanske pobrale so truplo, naštevale v joku Priamov rod so in množico žrtev iz ene družine. Tebe, mladenka, so v joku omenjale, tebe, ki žena 
kralju bila si in mati kraljevska in živa podoba Azije bujne, a zdaj le slab plen, ki Uliks zmagoviti ne bi ga maral, če Hektorja ne bi pred časom rodila; Hektor je komaj zadoščal, da mati je našla lastnika! Mrtvo telo te hrabre je duše objela in solze, kakor jih večkrat za kraj, za moža in sinove je lila, zdaj je zanjo točila. S solzami zalila je rano, usta s poljubi zakrila, po prsih že vajenih bila, sive lase si je v strjeni krvi med brisanjem trla, hkrati pa ves čas iz prsi podplutih glasno govorila: »Hčerka, ti matere svoje poslednja bridkost - saj ostalo drugega nič mi ni - mrtva si, rana je tvoja zdaj moja! Glej, da ne bi katerega svojih brez rane zgubila, ti si rano dobila. Menila sem, ti boš pred mečem varna, zato ker si ženska, a vendar si padla pod mečem. Isti, ki toliko tvojih je bratov usmrtil, je tebe, Troje rušitelj in strašni Ahil, ki vse mi pobral je. Potlej ko Paris in Fojb sta mu s puščico vzela življenje, mislila sem, da poslej se ni nam ga treba več bati. Vendar še zdaj se bati ga moram. Čeprav je že mrtev, zoper naš rod besni, še iz groba sovražnika čutim, zanj sem otroke rodila! Mogočni je Ilion padel, potlej še z groznim izidom končal se poraz je države, vendar se vsaj končal je. Le meni še Pergam ostal je, moja bridkost kar traja in raste, postaja vse večja. Toliko zetov, sinov in snah ter moža sem imela zdaj sem izgnana in revna, z grobov sem odtrgana svojih, dar za Penelepo; ta me kazala bo itaškim ženam, dala mi volno bo v prejo in zraven tako govorila: »Tale tu Hektorja mati je slavna in Priama žena!« Toliko svojih sem prej izgubila; in ti, ki si žalost lajšala mojo edina, si sovražnemu grobu v tolažbo. V žrtev sovražniku zgolj sem rodila, le kaj naj še čakam, kaj naj bom trdna še, kaj me še, pozna starost, zadržuješ? Kaj le zato me ohranjate starko še zdravo, da gledam nove grobove, okrutni bogovi? Le kdo bi pripisal Priamu srečo po tem, ko je Troja porušena padla?

Srečen je, saj je umrl! Ne vidi, hči moja, te mrtve, svoje življenje obenem je s svojim kraljestvom zapustil. Misliš, kraljična, da zdaj s slovesnim pogrebom računam, misliš, da tvoje telo gre v grobnico prednikov naših? Te usode ni več. V spomin boš dobila le solze matere svoje in zraven peščico tujinskega peska. 
Vse sem zgubila. To, kar mi ostaja, da hočem živeti vsaj še za hip, je sin, ki materi vseh je najljubši; včasih najmlajši med svojimi brati je bil, a zdaj sam je $\mathrm{h}$ kralju ismarskemu bil je poslan Polidor v tujino. Kaj še mudim se, da nisem medtem ti že z vodo izmila rane prebridke in $\mathrm{z}$ njo sledov krvavih $\mathrm{z}$ obraza? «

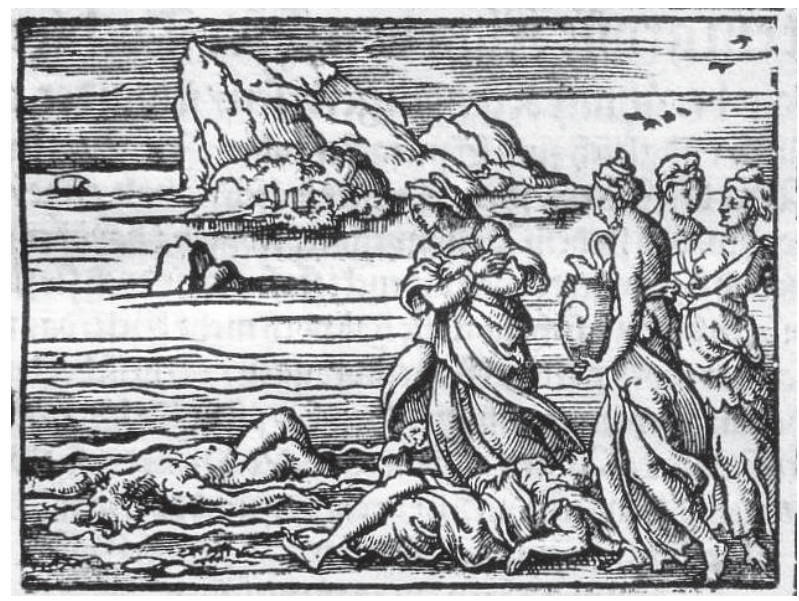

Slika 11: Hecuba Polydorum invenit (13.523-544)

To je dejala in šla je k obali s počasnim korakom, las osivelih in zmršenih. »Dajte, Trojanke, mi žaro, « bedna je kriknila; rada zajela bi čiste si vode. Truplo Polidorja tam, ki val ga je vrgel na kopno, v ranah neznanskih zagleda, zadanih od traškega meča. Žene trojanske so kriknile, ona je vsa obnemela v žalosti svoji, ker množico solz, ki so vrele navznotraj, z glasom je vsrkala žalost: v otrplosti svoji podobna skali je trdi bila, zdaj v tla je zrla s pogledom, včasih svoj mračni obraz obrnila je k nebu, pa zopet gledala sinov obraz na tleh in rane njegove, zlasti še rane; in vedno bolj besna je našla odločnost. Srd ji vzkipel je kot v dneh kraljevanja, zato je sklenila v jezi načrt maščevanja, le to ji bilo je še v mislih. Prav kot levinja zbesni, če mladič je ugrabljen, in lovcu, zdaj še nevidnemu, vneto sledi po njegovih stopinjah, tokrat Hekaba, ko v njeno se žalost je vpletla še jeza, let pozabila število je, gneva pa ni pozabila: k strašnemu klavcu je šla, Polimestorju, češ, naj jo sprejme. Rekla mu je, da v pogovoru z njim bi mu rada razkrila skrito zlato, ki nato naj ga njenemu sinu prenese. 


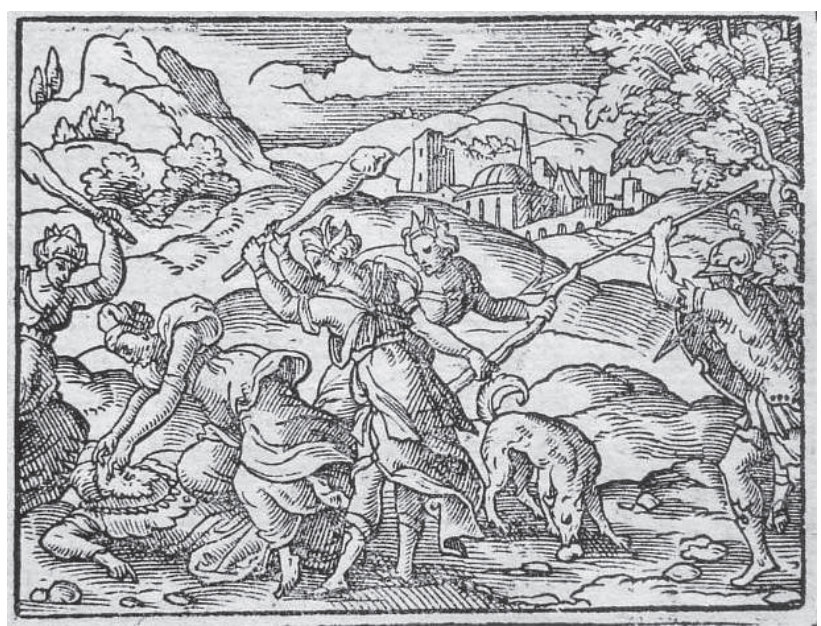

Slika 12: Ultio Hecubae (13.545-571)

Res ji verjel je Odrisijec; plena željan kot navadno $\mathrm{k}$ njej je prišel na razgovor in zvito, priliznjeno rekel: »Nič ne odlašaj in sinu, Hekaba, pokloni darilo, vse bo njegovo, kar daš, in vse, kar doslej si mu dala, to pri bogovih prisegam!«Srepela je vanj, ko je tvezel; on je lažnivo prisegal, v njej jeza je vrela, vzkipela v tem ga zgrabila je, sklicala vrsto ujetih je mater, 560 prste $\mathrm{v}$ hinavske oči zasadila, oči iz duplin mu živemu trgala - srd je moč - potem pa vtaknila roke, še vedno krvave, zločincu v očesni votlini, ne več v oči, ker njegovih oči nikjer več bilo ni. Besni ob tej poškodbi vladarja začeli Tračani kamne so vanjo metati in lučati kopja v Trojanko. Ta pa s hripavim renčanjem za vrženim kamnom je tekla, hlastno z zobmi ga zgrabila; hotela jim nekaj je reči, vendar je lajala. Še je tam kraj, ki tale dogodek dal mu ime je, a ona v spominu še dolgo nosila prejšnjo bridkost je med laježem tam po sitonskih poljanah. Njena usoda Trojanke, sovražne Pelazge in tudi vse je bogove ganila do zadnjega, da, še Junona, Jupitru žena in sestra, priznala je to, da Hekaba take usode in konca si ni zaslužila $\mathrm{z}$ ničimer. 
Preobrazba Memnonove grmade v ptice

Zora je Troji nekoč pomagala, a zdaj ni več našla solz za zrušeno Trojo, skrbi za bedno Hekabo.

Lastna je mučila skrb in žalost družinska boginjo:

Memnon je padel. Na frigijskem polju ga žalostna mati

zlata je videla pasti pod silnim Ahilovim kopjem.

V hipu, ko to je zagledala, barva, ki jutra odeva,

vsa je zbledela in jasno nebo so zastrli oblaki.

Mati ni gledati mogla, ko truplo je ogenj požiral;

nič se ni sramovala, pred Jupitra padla je v solzah,

tam mu z lasmi je spuščenimi z roko objela kolena,

z glasom prosečim najvišjemu bogu vsa solzna je rekla:

»Izmed boginj, kar v zlatem ozračju jih biva, najnižja,

- tudi svetišča na svetu vesoljnem so moja prav redka -

vendar pa le kot boginja prihajam, a ne, da prosila

templjev bi, praznikov, niti oltarjev, razbeljenih z ognjem.

Ženska sem; vendar pomisli, kje vse ti kot ženska koristim,

590

vsakokrat, kadar temo varujem pred novo svetlobo,

veš, da vredna daru sem. Pa ne, da bi zanj se pulila,

ni mi za to, da bi zase iskala priznanja zaslugam.

Tu sem zato, ker zgubila sem Memnona, sina; junaški

stricu zaman je v pomoč šel $z$ orožjem in v prvi mladosti

silni Ahil mu življenje je vzel, kot ste sami hoteli.

Daj, bogov najvišji vladar, in nakloni mu, prosim,

čast za uteho po smrti in mater pri tem potolaži."

Jupiter prošnjo je slišal. Ko Memnonova se grmada

v ognju velikem sesedla je, črnega dima plasti so

600

dan zatemnile, da sonce ni skoznje več moglo prodreti,

prav kot ne more prodreti, ko dvigajo $\mathrm{z}$ reke se megle.

Črni pepel se je dvigal in motal in zgoščal v telo se,

že je obliko dobival, zajemal življenje iz ognja,

lahek dobival peruti - podoben je najprej bil ptici,

potlej pa prava je ptica postal in je s krili udaril,

prav kot so hkrati udarile s krili še sestre neštete;

vse na enak so način se porajale, v ognju so zrasle.

Trikrat grmado so vse obletele in trikrat so hkrati

v zrak zavreščale, $v$ četrtem poletu so spet se ločile -

610

besno so v jatah sovražnih se dveh spoprijele, se tolkle

s trdimi kljuni in kremplji, ki krivi bili so kot kavelj;

slednjič so spet utrudile peruti in prsi sovražne,

zviška so padle v sorodni pepel kot žrtve posmrtne,

$\mathrm{z}$ živo zavestjo spomina, da sam junak jih rodil je. 
Ptice po njem so dobile ime in danes še vedno pravijo jim memnonide; ko sonce ozvezdja prehodi, zberejo se in se znova na smrt in življenje borijo. Drugim se torej Dimántida smili, ko laja po pasje,

Zora pa sama žaluje in zdaj še vedno ljubeče solze preliva, roseč jih nenehno po zemlji vesoljni.

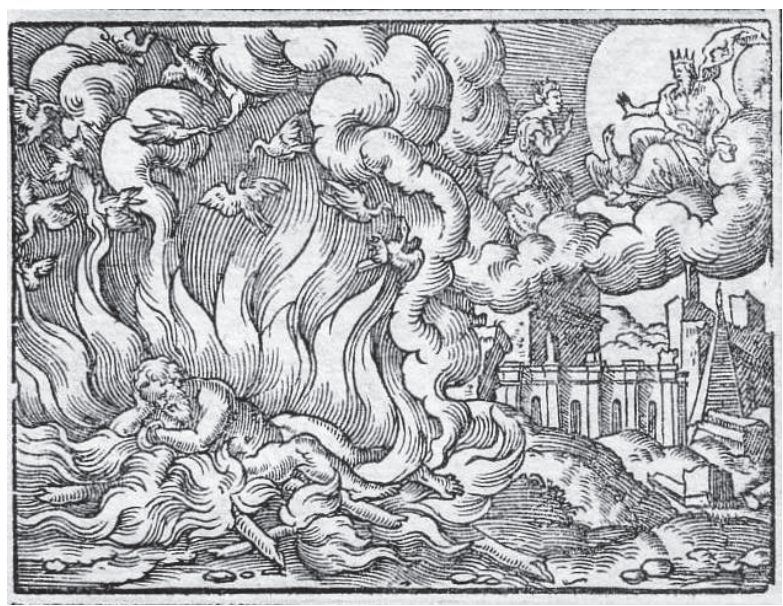

Slika 13: Memnon crematur (13.576-619)

\section{Enejevo potovanje}

Ni pa pustila usoda, da z zrušeno Trojo bi tudi upanje šlo. Svetinje in drugo svetinjo - očeta, breme častitljivo, sin Kiterkin je nesel na plečih.

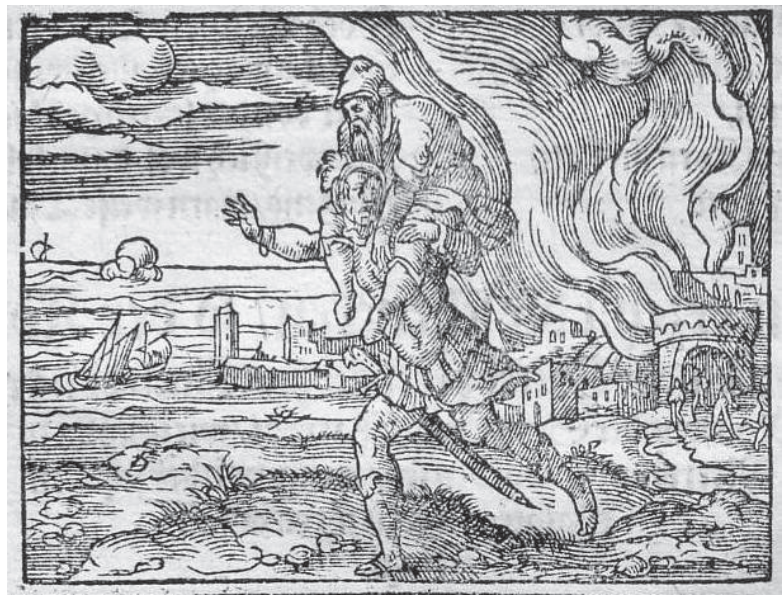

Slika 14: Pius Aeneas et Anchises (13.626-628) 
Ta edini si plen je izbral od vsega bogastva; s sinom Askanijem vse iz Antandra na svoji je ladji bežal čez morje in mimo zločinske šel traške obale, te, ki nedolžna je kri jo Polidorja prej pordečila, v sapi ugodnih vetrov, ob ugodnih tokovih na morju, s spremstvom prispel je na Delos, na otok, kjer vlada Apolon.

\section{Anijeve hčere}

Tam ga je Anij sprejel, vladar in Fojbov duhovnik, dal mu je prostor v svetišču in v dvorcu, razkazal mu mesto, templje mu slavne pokazal in dvoje dreves, za kateri nekdaj Latona ob svojem porodu držala je $\mathrm{z}$ roko. Najprej zmočili kadilo so z vinom in vrgli ga v ogenj, čreva zaklanih so krav še kot žrtev obredno zažgali, potlej pa v dvorec odšli so in tam na preprogah debelih Cererin dar uživali z Bakhom tekočim obenem. Dobri Anhiz se tedaj je oglasil in tole povprašal: »Fojbov odlični duhovnik, poslušaj, menda se ne motim, $\mathrm{v}$ dneh, ko sem prvič bil tu in sem videl to mesto, imel si sina in hčerkice štiri - če zdaj spomin me ne vara." Z glavo, ki bel mu jo trak je obdajal, prikimal je Anij in odgovoril: »Junak preslavni, prav nič se ne motiš, videl petero otrok si očeta, ki vedno bolj sam je, res, opoteča se sreča tako človeku obrača.

V kakšno pomoč mi je sin odsotni tam daleč na Andru? Otok po njem je dobil ime, ki kraljuje in vlada.

Delijec dal mu je dar preroštva in Liber je hčeram večji dal dar, kot kdo bi verjel in mogel želeti. Kar je katera prijela, se vse je takoj spremenilo $\mathrm{v}$ žito in v vino tekoče in v sadež okusni Minervin $s$ tem so mi res na mnogo načinov koristile hčere. Ko pa za dar in posebne sposobnosti zvedel Atrid je, Troje rušitelj - mi tudi, pomisli, smo tukaj čutili vaše nesreče vsaj nekaj - jih zoper njih voljo odtrgal s silo orožja iz rok je očetovih, zraven pa terjal, naj z nebeškim darilom mu hranijo moštvo na ladjah. Kamor že koli katera je mogla, tedaj je zbežala: dve sta prišli na Evbojo, še dve pa k bratu na Andros. Vojska prišla jih je tja zahtevat, grozili so $\mathrm{z}$ vojno. Strah je pri bratu premagal ljubezen, izročil je sestri. Vendar boječemu bratu vse to boš nemara odpustil, 
ni bil niti Enej ne Hektor, da branil bi Andros, ni bil junak, ob katerem ste vi desetletje zdržali. Že so ujetima skušali dati okove na roke; te so še proste bile, zato sta jih dvignili k nebu v krik: »Bakh oče, pomagaj!« In njunih darov darovalec res je pomagal, če to je pomoč, da koga uničiš, naj bo način še tako nenavaden. Kako izgubili svojo zunanjost takrat sta, ne vem in ne morem ti reči. Vem pa za konec, dobili sta perje, kot dve golobici beli tedaj odleteli med ptice sta tvoje soproge.«

Take in druge pogovore tam med jedjo so imeli, ko izza miz so se dvignili, šli so slednjič počivat. $\mathrm{Z}$ dnem zarana so vstali in $\mathrm{v}$ Fojbovo šli preročišče: $\mathrm{k}$ materi stari naj grejo, $\mathrm{v}$ njen kraj, jim je to naročilo. Kralj jih pri tem je pospremil in dal za slovo jim darove: žezlo Anhizu poklonil je, plašč in tok vnuku, Eneju dal je vrč, ki ga Ters Ismenec, gostinski prijatelj, svojčas prinesel je v dar iz svoje aonske dežele. Ters mu je vrč poklonil, izdelal pa Alkon Hilejec, vanj je nazorno začrtal premnoge zgovorne podobe. Mesto bilo je na njem, ki vrat je sedmero imelo, ta so ime izdajala, mesto spoznal si po vratih. Ognji, grmade, gomile in sprevod pogrebni pred mestom, ženske razmršenih las in otožno razgaljenih prsi, vse je izdajalo žalost. Še nimfe si videl jokati poleg presahlih studencev in drevja brez vsakega listja, z golimi vejami, koze obirale žgoče so skale. Hčeri obe Orionovi v Tebah je mož upodobil tu, kako se je ena nežensko zabodla pod vratom, tam, kako se je s skrhano puščico druga ubila. Padli za svoje sta ljudstvo in v lepem sprevodu po mestu nesli obe so, na kraju odličnem obe so sežgali. $\mathrm{V}$ tem, da bi rod se ohranil, v pepelu deviškem sta vznikla dva mladeniča - rekli so jima Korona - in prva šla sta v sprevodu, v katerem pepel njunih mater so nesli. Toliko raznih podob se bleščalo je v bakru starinskem, zgoraj pa vrč je bil ves okrašen s pozlačenim akantom. Prav nič slabših darov jim niso vrnili Trojanci; dali duhovniku škatlo kadilno so s skledo darilno, zraven naglavni okras iz zlata in z dragimi kamni. 


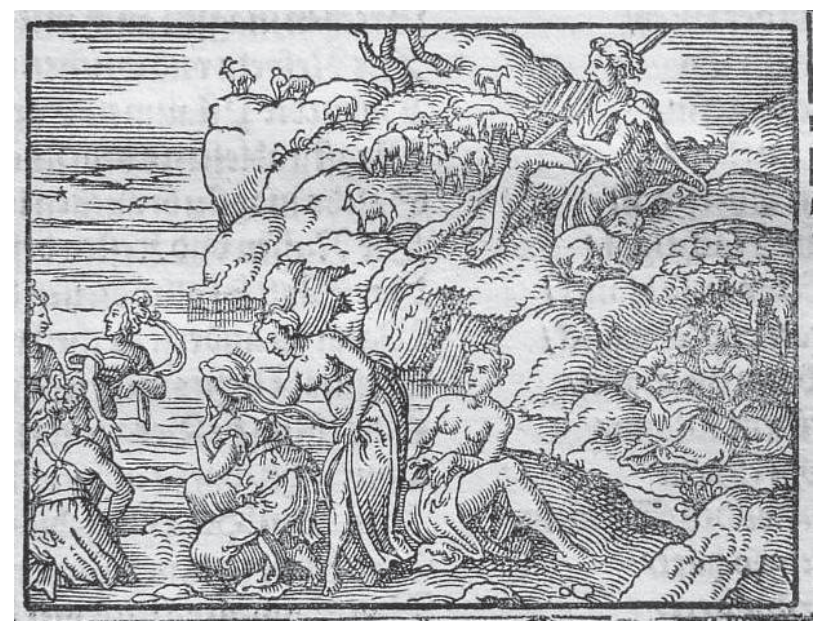

Slika 15: Polyphemus, Galatea et Acis (13.730-869)

\section{Akid, Galateja in Polifem}

Vedeli so, da kot Tevkri od Tevkra izvirajo, šli so najprej na Kreto, kjer ni jim dišalo preostro podnebje, niso ostali, pustili so otok s sto mesti za sabo, raje sklenili so pluti do luk na avzonski obali. Vihra je divja jih vse razmetala; prišli so v nevarno luko strofadsko in tam jih pregnala je ptica Aelo.

Dalje so mimo Dulihija, Itake, Sama in tudi mimo neritskih domov v kraljevini pretkanca Uliksa jadrali, zrli v Ambrakijo, v to, ki so svojčas bogovi zanjo se sprli, in v kip razsodnika, ki kamen postal je, zdaj pa Apolon iz Aktija kraju k slovesu pomaga. Šli so v dodonsko deželo in videli hrast njen preroški, potlej Haonski zaliv, kjer sinovom mološkega kralja svojčas so zrasle peruti, da vsi so ušli iz požara. Dalje nato v sadonosno deželo Fajakov so pluli, šli so v Epir in v Butrót, ki se zdel jim podoben je Troji, to pa zato, ker tam kraljeval je frigijski vedež. Tam so prihodnost spoznali, prav vse jim je čisto natanko Helen, sam Priamov sin, napovedal in dal jim nasvete. Šli so naprej k Sikaniji, s tremi jeziki zajeda v morje se - proti deževnemu jugu Pahin je obrnjen, rahlim zefirom je vdan Lilibaj, rt tretji pa, Pelor, gleda Medveda, ki morja ne mara, in severni veter. 
Sem pripluli so Tevkri in z vesli ob morju ugodnem ladja pod noč je dosegla zanklejsko peščeno obalo. Skila na desni, na levi nemirna Haribda grozili

še sta jim: ladje ugrabljene bruhala ta je, a ona $z$ divjimi psi si obdajala črno telo je, obraz pa bil je dekliški, če ni izmišljeno vse, kar so pevci rekli o tem, in včasih bila je resnična mladenka. Mnogi bi snubci jo radi, a kadar je te zavrnila, $\mathrm{k}$ nimfam pomorskim - imele so rade jo - šla je in zbranim pravila, $s$ čim izigrava ljubezen mladeniških snubcev.

Dala nekoč Galateja pri njej si lase je česati; nimfa je vzdihnila, Skili je tole zamišljeno rekla: »Tebe, o deklica, vendar ne snubijo moški hudobni, znaš jih nekaznovano odbiti - in to tudi delaš. Jaz pa, Nerejeva hči, ki me sinja rodila je Doris, jaz, ki varna bila med množico svojih sem sester, res ubežala ljubezni Kiklopovi sem, a le v žalost.« To ji je rekla in sredi besed so jo solze zalile. $S$ prstom jih belim otrla je deva in, ko je boginjo potolažila, je rekla: »Daj, pripoveduj mi, predraga, kakšen je vzrok, da si žalostna? Zvesta sem, nič mi ne skrivaj!« Hčeri Krateja je to nereida nato odvrnila: »Akid je sin bil nimfe Simajtide; oče je Favn bil, materi bil in očetu je vedno v veliko veselje, meni še v večje, ker vame edino se fant je zaljubil. Lep je bil res in pri šestnajstih letih njegovih poganjal prvi je puh, ki mu lica je nežna narahlo obrobljal. Jaz sem ga vedno iskala - Kiklop pa je hodil za mano. Nič ne sprašuj, če tedaj Kiklopa sem bolj sovražila ali pa Akida bolj ljubila; povem ti - enako. Kolikšno moč imaš, Venera blaga! Še tisti okrutnež, strašen gozdovom celo, ki nihče ga ni videl brez kazni, on, ki Olimp je visoki preziral z vsemi bogovi, čutil je, kaj je ljubezen, in gorel je v svoji neznanski sli, v poželenju do mene, ki vsega takrat je prevzelo. Svojo drobnico je scela pozabil, pozabil votline. Tudi za svojo lepoto, da všeč bi mi bil, poskrbel si, $\mathrm{z}$ grabljami česal si trde lase, Polifem, in s srpom zmršeno brado si rezal si, v vodi pa divji obraz svoj ogledoval in še ga in še si olepšati skušal. Sla ubijalska, okrutnost in z njo krvoločnost neznanska šle so in ladje so varno pristale in varno odplule. Telem tedaj na Sicilijo tjakaj pod Etno prišel je, 
Telem, sin Evrimov, njega nobena ni varala ptica, tam obiskal je Polifema groznega in mu je rekel: »Tole oko, ki imaš ga na čelu, Uliks ti pobral bo.» S smehom Kiklop je odvrnil: »O ti, najneumnejši vedež, motiš se, prej mi ga druga je vzela! « In ni upošteval resne napovedi, s silnim korakom je šel ob obali, tlačil jo je in utrujen se vračal je $\mathrm{v}$ mračno votlino. $\mathrm{V}$ morje kot klin se tam gora zajeda $\mathrm{z}$ raztegnjenim vrhom, morski valovi $z$ obojne strani se zaganjajo vanjo. Nanjo se divji Kiklop je povzpel in na sredo je sedel, zraven drobnica je volnata šla, nihče je ni silil.

Potlej ko k nogam odložil je smreko (za jambor na ladji znala bi biti, a on se je nanjo pri hoji opiral), vzel je svirel iz stoterih trstik narejeno, da gore slišale vse so njen glas pastirski in morski valovi. Jaz sem se skrila takrat v pečevju, bila sem v naročju Akida svojega, sama na svoja ušesa sem zdaleč pesem ujela in njene besede razbrala takole:

»O Galateja, bolj bela, kot snežni cvet šipkov se beli, bolj kot poljana cvetoča, bolj vitka kot jelša visoka, bolj kakor steklo bleščeča in bolj razigrana kot jarček, vse bolj gladka kot školjka, ki morje jo pere in gladi, ljubša kot sonce pozimi in ljubša kot senca poletna, vzvišena bolj od platane visoke po rasti in lepša, slajša kot zrelo si grozdje, svetlejša od svetlega leda, mehka kot puh labodji, bolj mehka od kislega mleka, lepša kot vrt namakani - lepša, ko ne bi bežala.

Taka pa divja si bolj kot bik podivjan, Galateja, trša od starega hrasta, varljivejša kakor valovje, zvita si bolj kot vrbova veja, kot bela je trta, nepremakljiva si bolj kot gore, bolj silna kot reka, bolj kakor pav čaščeni prevzetna, bolj žgoča od ognja, bolj kot osat si bodeča, bolj besna kot breja medvedka, bolj kakor morje si gluha, bolj jezna od zdražene kače, dalje še, kar bi najrajši preprečil ti, da, če bi mogel, hitra si bolj kakor jelen takrat, ko ga lajež preganja, hitra še bolj kot veter, kot ptica, ki leta pod nebom! Vendar, če prav bi poznala me, ne bi bežala pred mano, žal bi bilo ti odlašanja, ti bi me sama iskala.

V gori živim, v votlini, ki v živi je skali, da v njej se sonca v najhujši vročini ne čuti, ne čuti se mraza, 
kadar je zima. In veje šibijo pod težo se sadja, zlatu podobno na dolgoraztegnjenih trtah je grozdje, drugič je spet kot škrlat - in oboje bom zate prihranil. Sama z rokami boš svojimi jagode brala, ki v senci gozdni zorijo, jesenske drenulje boš brala in slive, ne samo tiste od črnega soka modrikaste, tiste bolj plemenite, ki svežemu vosku močno so podobne. Vzemi me brž za moža, dovolj boš imela kostanja, zraven dovolj jagodičnic, ker vsako drevo bo le zate.

Vsa ta drobnica je moja in ovc je še dosti v dolini, mnogo je skritih po gozdu in mnogo imam jih po stajah. Nič ne sprašuj po številu, ne morem ti reči natančno. Revež prešteva drobnico. In ni ti treba verjeti meni, ko tu ti jih hvalim, lahko se prepričaš, da komaj hodijo, vimena polna pri tem so jim skoraj napoti. Zraven je mlajša prireja ter jagenjčki v toplih ovčnjakih, v stajah imam poleg jagnjet enake starosti kozličke. Vedno zadosti je belega mleka, od tega ga nekaj hranim, da sproti ga pijem, spet drugo imam, da ga sirim.

Ne bi ti nosil samo cenenih slaščic za darila, ne le navadnih darov za dekle, kot so srne in zajci, ljubek kozliček, pa krotki golobi in najdeno gnezdo. Našel sem dva mladiča kosmate medvedke na gori, res, na las sta enaka, težko ju med sabo razločiš.

$\mathrm{Z}$ njima lahko se igraš. Ko sem našel oba, sem si rekel: »Ta dva medvedka bom zdaj obdržal, gospe ju bom nesel.«

Dvigni že, dvigni iz sinjega morja glavo svetlolaso, pridi že sem, Galateja, in mojih darov ne odklanjaj! Sam se dobro poznam, ker svojo podobo pred kratkim videl sem v vodi tekoči; ko tam sem se videl, povšečna moja zunanjost bila mi je. Glej me, resnično sem velik! Jupiter sam ni nemara nič večji od mene na nebu, kjer, kakor pravite vi, naj nekakšen bi Jupiter vladal. Gosti lasje mi štrlijo nad mračni obraz in mi pleča senčijo prav kot kak gaj. Da pokriva na gosto telo mi dlaka sršeča, nikar si ne misli, da v tem je grdota. Grdo drevo je brez listja in grdi so konji brez grive. Ptiči so s perjem pokriti in ovcam je kožuh v okrasje, brada in dlaka sršeča pa moškim podobno pristaja.

Eno oko imam sredi čela, a to je veliko 
prav kot kak ščit. Pa kaj, mar z neba ne gleda podobno Sonce na ves naš svet? In le eno oko ima Sonce!

K vsemu dodaj še, da vašemu morju roditelj moj vlada. Njega za tasta dobiš, usmili se me in usliši prošnjo ponižno mi, tebi edini sem jaz se uklonil. Jaz, ki me ni strah Jupitra s strelo pogubno na nebu, tebe bojim se, Nerejka, tvoj srd je hujši od strele. Tvoj prezir, tako se mi zdi, bi lažje prenašal, če bi se vseh ogibala. Ti pa odbijaš Kiklopa, zraven pa Akida ljubiš? On več je od mojih objemov? Kar naj ugaja sam sebi in tebi naj zraven ugaja, česar ne maram, zares, Galateja! Če kdaj bo naneslo, mojo občutil bo moč, ki je takšna, kot gre velikanu. Živemu drob bom iztrgal in ude njegove razmetal v polje in v tvoje valove - tako naj se s tabo združuje! Ves gorim, ljubezen užaljena peče še huje, zdi se mi, kakor da Etno in silo bi njeno ognjeno v prsih zdaj nosil. In vendar te to, Galateja, ne gane.«

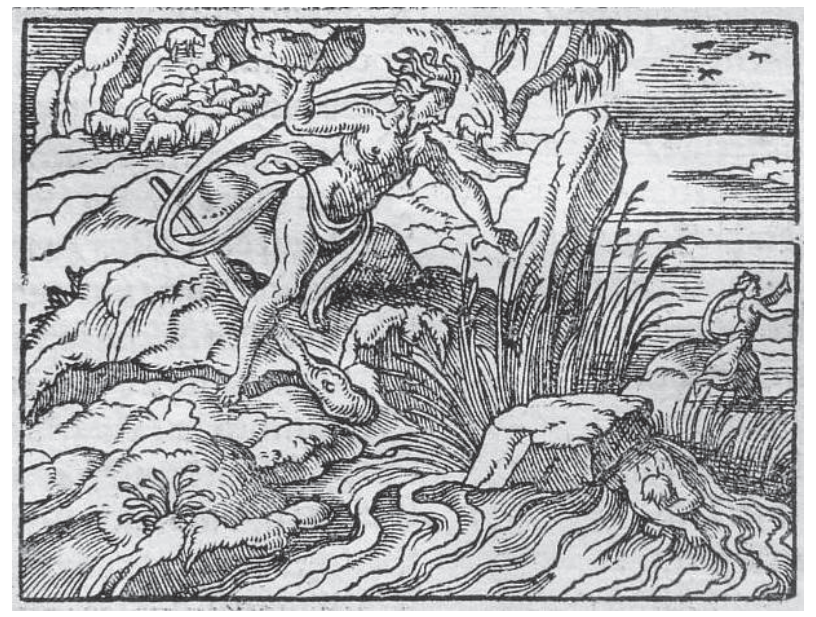

Slika 16: Polyphemus Acin necat (13.870-897)

\section{Preobrazba Akida v reko}

Javkal je, vendar zaman. Z očmi sem sledila od daleč; vstal je in besen kot bik, ki so kravo mu vzeli, ni mogel biti pri miru, po gozdu je blodil, po znanem gorovju. Ko pa je mene in Akida videl, ki nisva slutila 
niti se bala takrat, »Že vidim, « zarjul je, »in tale vajin ljubavni sestanek, za to poskrbel bom, bo zadnji!« Glas je bil takšen, kot gre Kiklopu, ki ves je razdražen, Etna celo se ob vpitju njegovem neznanskem je stresla. Jaz sem prestrašena v morje se bližnje takoj potopila, sin Simajtidin hrbet obrnil je, bežal in klical: »O Galateja, pomagaj mi, prosim, pomagajte, starši, zdaj se bliža mi smrt, sprejmite me v svoje kraljestvo!« Tekel za njim je Kiklop in odtrgal kos gore ter vrgel v tekmeca gmoto; čeprav le njen konec je fanta dosegel, Akida teža vogala je vsega pokrila pod sabo. Jaz sem storila tedaj, kar mogla sem še po usodi, vse sem storila, da Akid bi dedovsko moč si pridobil. Izpod hribine škrlatna pritekla je kri, ki na lepem rdečo je barvo začela izgubljati, tekla je rjava, prav kakor reka, ko prvo obilno deževje skali jo, vendar se kmalu je sčistila, tla so nad njo se razklala. Živa in vitka tedaj iz razpoke trstika je zrasla, iz odprtine prevótljene skale je voda privrela, kmalu nato pa, prečudno, iz nje se, krog ledij opasan, s trstjem ovit okrog novih rogov, je prikazal mladenič. Res, da bil je večji in ves posinjel po obrazu, vendarle bil je Akid, moj Akid; čeprav se spremenil v reko je, v reki poprejšnje ime je svoje ohranil.«

\section{Skila, Glavk in Kirka}

Nehala tu Galateja je s svojo pripovedjo, družba šla je narazen - tja v morje prijetno so šle nereide, Skila pa šla je nazaj, a ker ni si na morje odprto upala, tam je kar naga po žejavem pesku hodila ali, ko kje utrujena našla odmaknjen zaliv je, tam se je kopala v vodi, da v njej si je ude shladila. Glej, pljuskajoč po gladini tedaj je nov prebivalec morja globokega splaval do nje, sam Glavk, ki pred kratkim tam v evbojskem Antedonu ves se spremenil je. V strasti ves prevzet jo je snubil z besedo, da ne bi ušla mu. Vendar prestrašena hitro zbežala je in se povzpela urno na goro, ki dvigala tam se je v morski bližini. Spredaj je morje bilo, a visoka je gora štrlela strmo iz morja spet v morje, prehajala v en je vrhunec. Tu je obstala in varna ugibala, koga sploh gleda. 
Kdo je, pošast ali bog, v tej barvi? Lase je motrila, preko ramen so mu padali, zraven prekrivali hrbet, spodnji pa konec telesa prehajal mu v gladko je ribo.

\section{Preobrazba ribiča Glavka v morsko božanstvo}

Videl jo je, se naslonil na skalo tam blizu in rekel:

»Nisem pošast in nisem zverina, prikupna mladenka, bog sem povodni; Protej in Triton in tudi Palajmon, sin Atamantov, je nimajo večje moči na vsem morju. Prej sem bil človek, a bil sem določen za morje globoko, ker že takrat sem najrajši ob njem se mudil in ribaril. $\mathrm{V}$ mreže sem ribe zajemal in vlačil iz vode, spet drugič vrvico kje na trstiki ravnal in posedal na skali.

Blizu zelenega travnika tam je obala, dotika morja na eni se strani, na drugi je sočnata trava. $\mathrm{Ni}$ še rogato govedo mulilo je, niti je niso mirne objedale ovce in niso je dlakaste koze; niti čebela na cvetju si tam ni nog oprašila, niso iz njega se spletali svatbeni venci in nikdar tam še ni kosa kosila. Jaz prvi na tisto sem trato sedel, da mreže bi mokre posušil in hkrati preštel bi ribe ujete, ki prej jih slučajno je v mreže zaneslo ali ki prej jih je njih lahkovernost prignala na trnek. Vse sem po vrsti kar drugo za drugo položil na travo. Zdi se, da to je izmišljeno, a komu v korist naj se lažem? Ko se je trave dotaknil moj plen, so se ribe zganile, vzpenjale se in obračale tam se na suhem kot v morju. Čakal sem in se jim hkrati sam čudil, medtem pa je v vodo množica vsa se pognala, pustila je breg z gospodarjem. Dolgo strmel sem, ugibal, kaj neki je to povzročilo, ali kak bog ali trave je sok tako čudežno vplival. »Kje je rastlina, ki to ima moč? « sem se zbegano vprašal, trav sem nekaj natrgal, si v usta jih dal in jih žvečil. Čim so sokovi neznani iz trave pritekli mi v grlo, že sem začutil, da v prsih srce mi močneje utriplje, hkrati pa tudi, da želja v drugačno okolje ga vleče. Nisem se dolgo ustavljati mogel: »Pozdravljena, zemlja, nikdar te več ne obiščem, « sem rekel in vrgel se v morje. Morski bogovi so sebi enakega zdaj me sprejeli, zraven Tetijo in $\mathrm{z}$ njo Okeana prosili, naj tisto, kar je na meni človeškega, vzameta. To sta storila, 
očiščujoči zagovor devetkrat sta najprej izrekla in ukazala, naj v sto si rekah še prsi izperem.

Hitro od raznih strani prihrumele so reke in morje, vse se razlilo nad mojo je glavo. Do sem po spominu morem povedati, kaj se takrat je dogajalo z mano.

Drugega več ne pomnim, ker nisem bil več pri zavesti.

Ko sem se zopet ovedel, po vsem telesu drugačen

kakor poprej sem bil, da, še v mislih več nisem bil isti.

Prvič takrat sem opazil to brado rjavozeleno,

te lase, ki jih vlačim za sabo prek širnega morja, močna ramena in roke, vse sinje, in noge, ki v koncih kakor v plavutasto ribo tedaj so se čudno končale.

Toda le kaj mi zunanjost koristi, in kaj, da ugajam morskim bogovom, da sam sem božanstvo, če ti me ne maraš? « To je govoril in še bi, a Skila je jezna zbežala, on pa besnel je in ves razdražen, ker ni ga hotela, krenil je proti čarovnemu dvorcu Titanide Kirke.

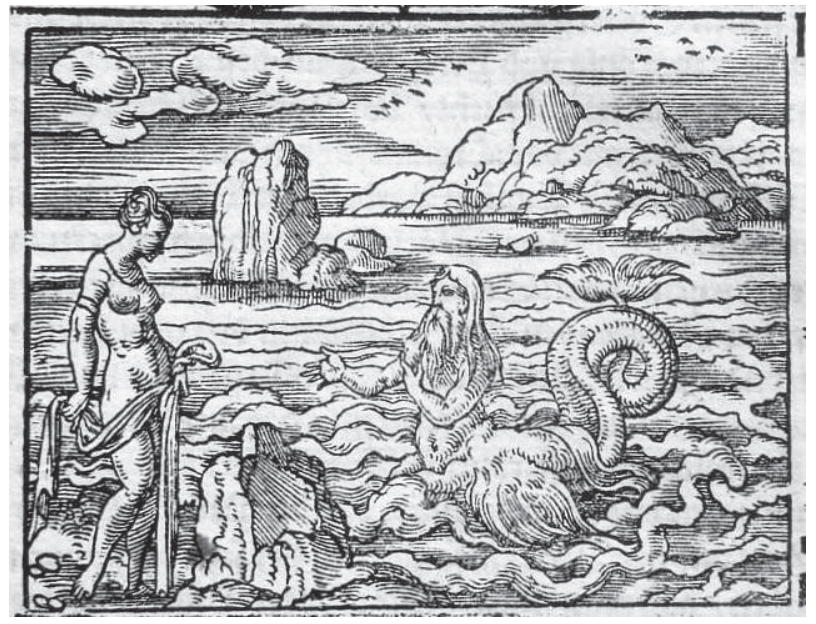

Slika 17: Glaucus Scyllam cupit (13.898-968) 
Štirinajsta knjiga

Preobrazba Skile v pošast in nato $v$ skalo

Že nad Gigantov goltance poveznjeni Etni in tudi poljem Kiklopov, ki niso poznala motike ne pluga niti ne vpreženih volov, da dolžna bila bi jim hvalo, hrbet je kazal Evbojec, nemirnih voda prebivalec; Zanklo in Regij nasproti je tudi že pustil za sabo z morsko ožino, ki ladje razbija in, še med obali stisnjena dve, Avzonijo loči od zemlje sicilske. Potlej čez morje Tirensko z rokami je močnimi plaval, $\mathrm{h}$ griču, poraslemu s travo, prišel je in k dvorcu, kjer Kirka, Sončeva hči, je živela in poln je bil razne zverjadi.

Tam jo zagledal je Glavk; pozdravi, ko ona odzdravi, reče ji: »Prosim, boginja, usmili boga se! Ti sama moreš ljubezni pomagati moji, če zdim se ti vreden. Kolikšna moč je zelišč, o Titanida, znano nikomur bolj ni kot meni, ker meni zelišča so vzela podobo. Da pa ti vzrok moje blazne ljubezni neznan ne ostane tam na italski obali nasproti mesenskemu mestu Skilo sem videl. Kar sram me je, da bi obljube in prošnje, sladke in še neuslišane svoje besede ponavljal. Daj, če v zagovorih res kaka moč je, zagovor izreci s svetimi usti, sicer pa, če bolje deluje zelišče, moč preizkušenih že in silnih zelišč uporabi! Vendar ne maram, da meni bi z lekom ozdravila rano, še naj ljubezen ostane - a hkrati naj ona se vname!« Kirka - nobena dovzetnejša kdaj za tak ogenj bila ni, bodisi da ji že v krvi bilo je to ali da jezna Venera, ker jo njen oče izdal je, je to povzročila tole mu vrne v odgovor: »Bilo bi še bolje, če dobil tako enakih želja bi in misli in tudi ljubezni. Vreden že sam si bil tega, da ona bi tebe prosila, tudi vprašala te bo, če daš upati, meni verjemi! Nič več ne dvomi in tudi, ko ne bi bil lep, kot si zdajle: jaz, ki boginja, ki hči sem bleščečega Sonca, ki s čari toliko zmorem in zmorem še toliko tudi z rastlinjem tvoja želela bi biti. Prezri prezirljivko prevzetno, ljubi ljubečo in hkrati tako obedve poplačaj!« Glavk, ko tako ga snubila je, s tem ji odvrne: »Prej v morju listnato drevje bo raslo, na gorah najvišjih pa alge, 
preden ljubezen bi moja se menjala, dokler bo Skila.« Zdaj se boginja užali: ker njemu ni škoditi mogla

niti hotela v ljubezni, jezila še bolj se je nanjo, ki jo bolj cenil kot njo je. Zaradi odbite ljubezni brž iz neznanskih zelišč je sokove iztisnila strašne, zmešala jih in s Hekate čarom jih zraven urekla, sinjo oblekla je haljo in mimo krdela zverjadi, krotke sedaj pred njo, odhitela je naglo iz dvorca. Šla proti Regiju je, ki nasproti zanklejskim je skalam, šla je po morju, razgretem od sončne pripeke: po njem je kakor po trdi kopnini hodila in res prehodila morsko gladino - in niti za hip si nog ni zmočila.

Tam je bil majhen tolmun, ki se v loku je krožil, in bil je Skili priljubljen kotiček oddiha, hodila je rada tja ob vročem vremenu in morju, ko sonce največje sredi neba je bilo in najmanjšo je delalo senco. Najprej skalila boginja tolmun je s čarovnimi strupi, potlej še sok iz korena škodljivega vanj je izlila, v temnem prepletu skrivnostnih, neznanih besed je nato še trikrat devet urokov mrmrala s čarovniškim glasom.

Skila prišla je in skoraj do pasa stopila je v vodo. Hkrati je že zaznala, da z lajanjem strašne pošasti ledja kazijo ji, toda spočetka ni mogla verjeti: to, da je njeno telo? Ne, bala režečih se psov je, stran jih otepala, tekla, bežeč jih vlekla je s sabo. Ko na telesu je boke in bedra in noge iskala, nič več ni videla udov, samo še kerberska žrela, stala na besnih je psih, na njihove hrbte tiščala ledja okrnjena s svojim drobovjem, molečim iz trupa. 


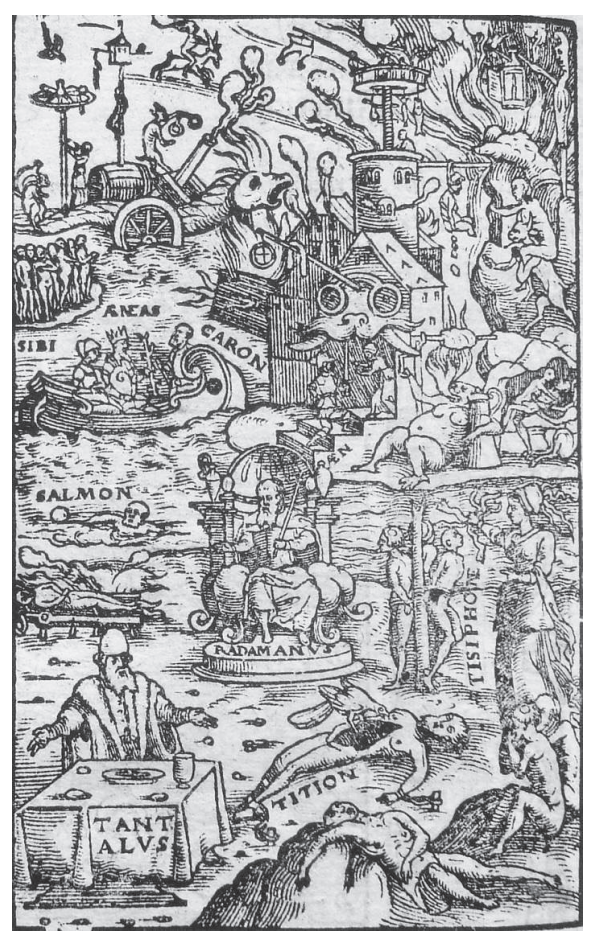

Slika 18: Scylla monstrum fit (14.51-74)

Glavk je v ljubezni zajokal in Kirke ni maral za ženo, vse preveč sovražno je čar zeli porabila.

Skila ostala na mestu je in je ob priliki prvi

v Kirkino jezo Uliksu pobrala še par spremljevalcev.

Malo je manjkalo, skoraj bi Tevkrom uničila ladje, vendar se prej spremenila $v$ pečino je, $v$ to, ki še danes tamkaj iz morja štrli; mornar se na daleč ji ogne.

Enej nadaljuje s potovanjem; preobrazba Kekropcev v opice

Njej in obenem požrešni Haribdi ušle so $\mathrm{z}$ veslanjem ladje trojanske, a tam iz bližine avzonske obale veter nasproten jih gnal je vse do libijskih bregov. Tu je Eneja v srce in v dvorec sprejela Sidonka, vendar ločitve od Frigijca svojega ni več prenesla, dala grmado je znesti na kup kot za žrtev in nanjo vrgla se je in zabodla: prevarana vse je zavedla. 


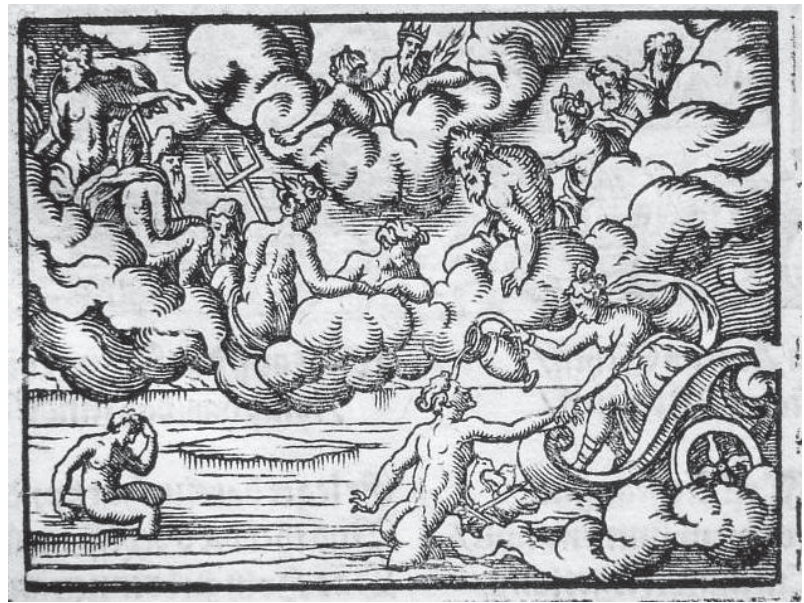

Slika 19: Dido et Aeneas (14.75-81)

On, Enej, je odšel iz novega mesta v puščavi, vrnil se v Erikov kraj je in k zvestemu vrnil Akestu, kjer je gomili očetovi žrtev posmrtno namenil. Z ladjami, te bi mu skoraj Junonina Iris požgala, potlej odplul je, zapustil kraljestvo Ajola in kraja hlapa žveplenega, kraja siren Ahelojevih skale. Ladja zgubila krmarja je, potlej k Inárimi plula, plula k Prohiti, zdrsela nato je še ob Pitekusah, mestu na skalnatem griču, ki svoje ime je dobilo po prebivalcih. Zaradi prevare in krive prisege oče bogov se nekoč na kekropsko je ljudstvo razjezil, v grde živali za kazen ljudi je zahrbtne spremenil, nič kaj podobne človeku in vendar nekako podobne. Ude je skrčil, zavihan jim nos je pod čelom potlačil, z gubami starcev ves njihov obraz preoral je, telo pa vse jim z rjavkasto dlako pokril in take nato je v mesto poslal Pitekuse, še prej pa nesrečnikom govor vzel je in rabo jezika, ki vajen je krivih priseg bil, pustil je le, da hripavo vreščeč se oglašati smejo.

Enej obišče podzemlje; zgodba o kumajski Sibili

Mimo teh krajev je šel in pustil na desni je mesto partenopejsko, na levi pa grob blagoglasnega pevca, sina Ajolovega, ter v pokrajino, polno močvirij, tam ob kumajski obali prijadral in stopil v votlino 
stare Sibile in prosil, da priti bi mogel v podzemlje, k duši očetovi. Dolgo Sibila kar v tla je strmela, potlej navdihnjena $\mathrm{z}$ dvignjeno glavo je rekla Eneju: »Kar si želiš, je veliko, o mož, ki si slaven po delih, ker se desnica ti v boju, ljubezen je v ognju skazala. Vendar ne boj se, Trojanec, dosegel boš to, kar želiš si, jaz te vodila bom, ti pa boš dom elizijski videl, videl poslednje kraljestvo sveta in videl tam tudi ljubo očetovo senco, saj ni kreposti nobena pot neprehodna.« Nato mu v gaju Junone Avernske vejo, bleščečo se v zlatu, pokaže, naj brž jo odlomi. Vidi grozotnega Orka bogastvo Enej in pradede, vidi, ko pride do tja, še očeta, junaka Anhiza, starčevsko senco. Izvedel je, kakšni zakoni so tamkaj, hkrati še, kakšne nevarnosti čakajo v novih ga bojih.

Ko po nasprotni je stezi od tam utrujen odhajal, trud si je lajšal v pomenku s prijazno kumajsko vodnico. $\mathrm{V}$ senci somraka je stopal po poti strahotni in rekel: »Bodi da prava boginja si ali bogovom najljubša, zame boš vedno boginja in vedno bom tudi priznaval: moje življenje je tvoj dar, ti si mi dala priložnost, iti v kraj smrti, ga videti, potlej pa spet se vrniti. Kadar na zrak pod nebo se povrnem, za tvojo uslugo tempelj zgradim ti in tebi na čast bom zažigal kadilo.« Vanj se ozre prerokinja, vzdihne globoko in pravi: "Nisem boginja in s svetim kadilom ni treba častiti glave človeške. Kar naj ti bo znano in se ne boš motil: večno življenje brez konca in kraja bi mogla dobiti, če žrtvovala bi svoje devištvo zaljubljencu Fojbu. Dokler je upal na to in pridobil bi rad me $\mathrm{z}$ darovi, »Kar le želiš, « je govoril, »izberi, devica kumajska, vse zaželeno dobiš! « Jaz kupček prahu sem zajela, nanj pokazala in nora želela, da mogla živeti toliko let bi še, kolikor drobcenih drobcev je v prahu, v prošnji pa to pozabila, naj leta ostala bi mlada. Vse mi je dal in tudi mladost bi mi večno naklonil, če bi se vdala mu. Ker odklonila sem Fojba z darovi, neomožena ostala sem. Srečnejša doba življenja hrbet mi že obrnila je, $\mathrm{z}$ omahujočim korakom starost nadležna prihaja. Še dolgo bo treba trpeti. Sedem že vekov živim, da število prahu bi dosegla, tristo še žetev in tristo trgatev še videti moram. 
Čas bo prišel, ko tole telo mi bo dolgo življenje skrčilo in ostarelemu in že izžetemu dalo težo najmanjšo. Da bog me je ljubil in všeč mu bila sem, tega ne bo verjel nihče. Nemara sam Fojb bo name pozabil takrat, nemara tajil bo ljubezen.

Vsa spremenjena takrat bom, nihče me več ne bo videl, slišal moj glas bo samo, ker glas po usodi ostane."

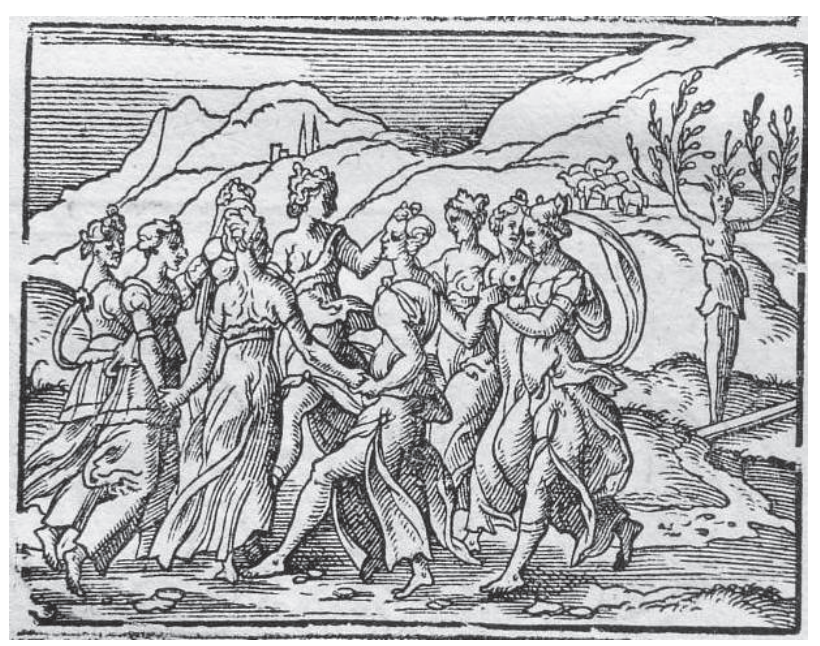

Slika 20: Aeneas apud inferos (14.101-157)

Prihod v Kajeto; Ahajmenid pove, kako je pobegnil Polifemu

To je dejala Sibila. Enej iz pokrajine Stiksa

v mesto evbojsko nato po strmi se poti je vrnil.

Tu je v skladu z navado Trojanec opravil daritve.

Šel je k obali, ki ni še imena rednice imela.

Tu Makarej je Neritčan, tovariš lisjaka Uliksa, sam se ustavil nekoč, utrujen od dolgih naporov. 


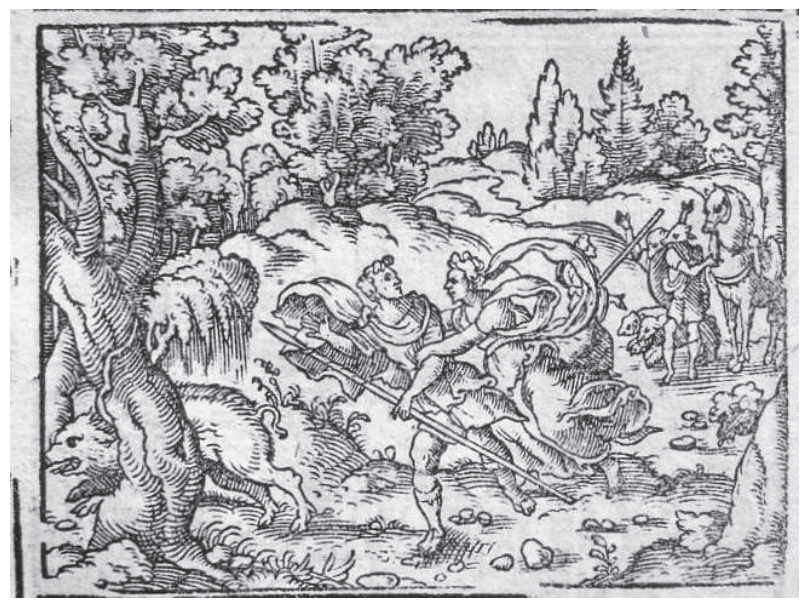

Slika 21: Errores Ulixis (14.157-164)

Tam Ahajménida, ki so pustili v pečevju ga Etne, videl nekoč je in, ko ga nenadno je našel, čudeč se, da je še živ, ga je vprašal: »Te kak je slučaj, Ahajménid, ali te bog je ohranil? Zakaj se kot Grk na barbarski ladji prevažaš? In kam je namenjeno vaše brodovje? « To ga je vprašal, nakar Ahajménid mu, nič več raztrgan, v redu že, ne v oblačilu, ki prej ga je s trni zapenjal, rekel je: »Ne, da še enkrat v Polifema moral bi zreti, videti gobec njegov, ki ga kri je človeška oblila ljubša od doma in ljubša od Itake ta mi je ladja, bolj kot očeta spoštujem Eneja. Nikdar ne bom mogel dosti hvaležen mu biti, četudi bi vse mu povrnil. Glej, govorim in diham ter gledam nebo in pa sonce, morem sploh biti za to nehvaležen in to pozabiti? On me je rešil, da moja ni duša Kiklopu šla v grlo, tudi če luč življenja mi tu, ta trenutek, ugasne, $\mathrm{v}$ grobu bom ležal lepo pokopan, ne v vampu njegovem. Veš, kako je tedaj mi pri srcu bilo - če že strah ni vzel mi zavesti - ko tam ste pustili me in sem vas videl pluti po morju? Zaklical bi rad, a kaj, ko izdati bal sem sovragu se. Tudi Uliksovo vpitje bi vaši skorajda škodilo ladji. Kiklopa sem videl, ko skalo grozno od gore odtrgal in vrgel tja v sredo valov je. Videl sem tudi, kako odletela je vržena skala kot iz metalnega stroja iz roke orjaku, in bal se, ker sem pozabil, da nisem na ladji med vami, da val bo ali pa silni udarec vso ladjo razbil in potopil. 
Vi ste mu $\mathrm{z}$ begom ušli in rešili pred strašno se smrtjo, on pa obšel stokajoč je vso Etno in z roko je grabil slep po gozdovih na njej, če koga nemara bo našel. Zraven se slep ob skale je ostre zadeval in roke okrvavljene je k morju molil in preklinjal Ahajce s temi besedami: »O, če slučaj bi mi vrnil Uliksa ali pa koga njegovih, kako bi si jezo ohladil! Drob bi pojedel njegov in še živo telo bi raztrgal s svojo desnico, njegova bi kri omočila mi grlo, udje iztrgani, ti bi pod mojim zobovjem drhteli. Potlej bi nič ali malo le dal na oko izgubljeno!« To in še več je govoril, a jaz od strahu prebledel sem, zroč mu v obraz, ki še vedno od klanja je bil okrvavljen, $\mathrm{v}$ roke njegove okrutne in $\mathrm{v}$ prazno očesno votlino, $\mathrm{v}$ ude in v brado, ki trda bila od krvi je človeške. Smrt mi bila pred očmi je kot zlo, še najmanjše od možnih. Že sem ga videl, kako me bo zgrabil, kako bo pospravil moje drobovje si v svoje; v spominu ostal mi prizor je hipa, ko videl Kiklopa telesi tovarišev dveh sem trikrat in štirikrat vreči z vso silo neznansko ob zemljo. Vrgel se nadnju potem je, kot lev kosmati ju trgal, drob in meso in bele kosti in mozeg in ude, žive na pol še, okrutnež, v požrešni je tlačil želodec. Kakor bi bil brez krvi, sem se tresel in žalosten stal sem, žročega zroč, ko iz ust zalogaje krvave je metal, bljuval pijan grižljaje iz ust, pomešane $\mathrm{z}$ vinom. Taka usoda se revežu meni pripravlja, sem mislil. Mnogo še dni sem se skrival, ob šumu sem vsakem se tresel, smrti sem hkrati se bal in si želel obenem umreti, glad sem preganjal z želodom in s travo, pomešano z listjem. Sam brez moči in brez upa sem čakal na smrt in na kazen. Ladjo sem tole po dolgem obdobju zagledal in z znaki prosil rešitve; ko sam sem pritekel do morja k obali, ganil sem jih: trojanska me ladja je - Grka - sprejela. Daj, še ti mi, predragi tovariš, povej o usodi našega vodje in spremstva, ki s tabo je plulo prek morja!« 


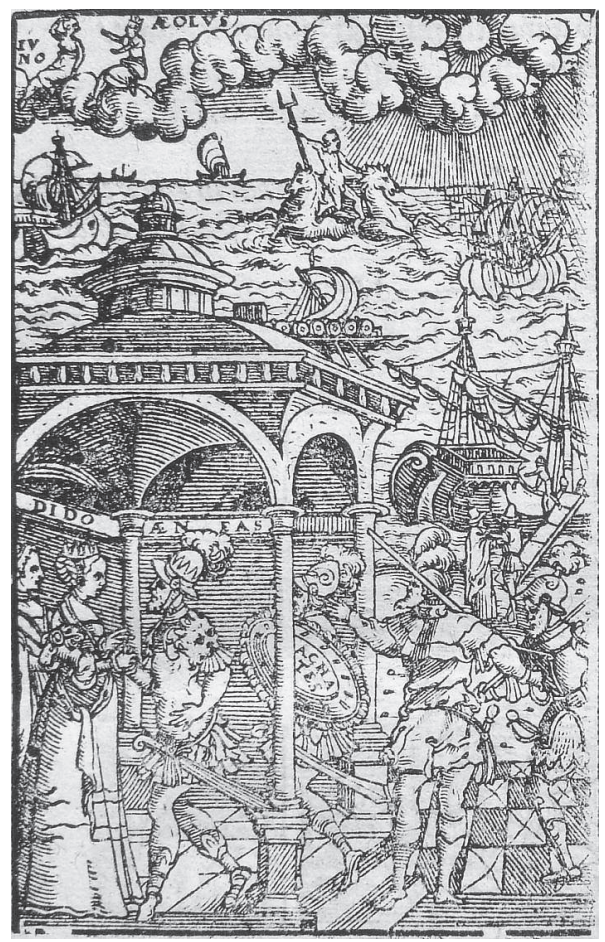

Slika 22: Polyphemus furens (14.165-222)

Makarejeva zgodba: Odisej in meh $z$ vetrovi

»Ajol, « začel Makarej je, »etrurskemu morju kraljuje, Ajol, ki vnuk je Hipotov, in brzda zaprte vetrove: te je Dulihijec dobil ujete v mehove volovje čudno darilo! - in potlej ob sapi ugodni devet dni jadral je dalje in že zaželeno je zemljo zagledal. Toda ko dan po deveti deseta se zora prikaže, spremstvo prevzame zavist, češ, najbrž zlato je v mehovih, $\mathrm{v}$ želji po plenu na mah mu razveže ujete vetrove; $\mathrm{z}$ njimi je moral nazaj tja, od koder priplul je po morju, v luki krotilca se Ajola vnovič je z ladjo ustavil. $\mathrm{V}$ mesto potem Lajstrigonovo staro, tja v Lamo prišli smo, kjer Antifát kraljeval je deželi. In jaz in dva druga, « nadaljeval Makarej je, "poslani bili smo do njega. Komaj rešila sva $\mathrm{z}$ begom se jaz in tovarišev eden, tretji med nami pordečil je s svojo krvjo Lajstrigoncu usta prekleta. Za nama bežečima pa Antifat je zbral krdelo in šli so in skale in hlode metali, 
moštvo na ladjah in ladje potapljali hkrati. Le ena ladja ušla je, na njej pa Uliks s peščico še živih.

Žalostni spričo tovarišev v tožbah in solzah smo končno v tisto deželo prišli, ki tukaj jo vidiš od daleč.

Veruj, od daleč le treba je gledati otok, kjer bil sem.

Sin boginjin, pošteni Trojanec - po vojni končani nič več sovražnik - Enej, sedaj te svarim, da izogni temu otoku se, ogni se Kirke nevarni obali!

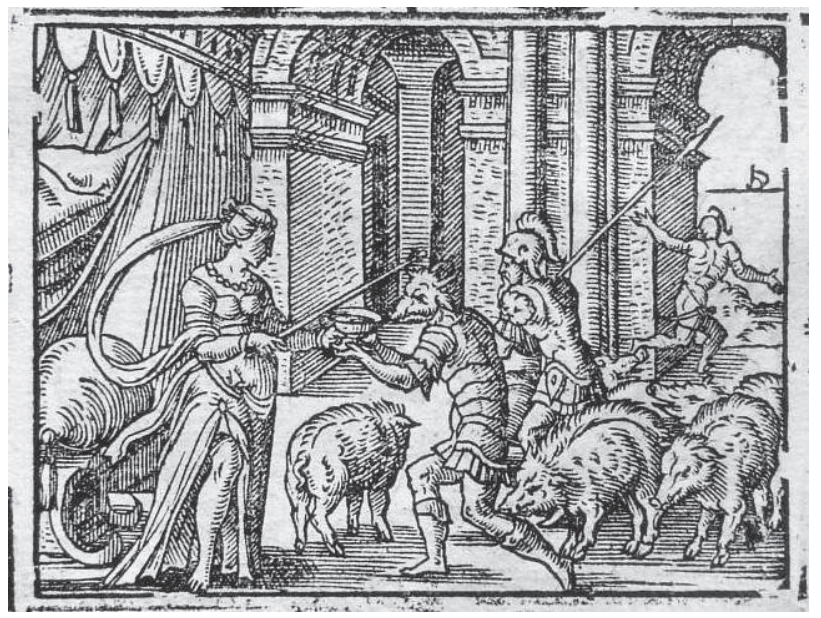

Slika 23: Domus Circae (14.248-307)

\section{Kirkin otok}

Mi po pristanku na njenem obrežju sploh nismo hoteli k njej oditi, preveč Antifata imeli smo v mislih, hkrati Kiklopa še divjega, vendar po žrebu izbrani iti smo morali v dvorec neznani. Izžrebani šli smo jaz in prijatelj Polit, Evriloh, Elpenor, ki ljubil vino preveč je, in dvakrat devet še tovarišev drugih. Ko smo do njenega dvorca prišli, smo obstali pred pragom, tisoč volkov in med njimi medvedov in levov navala zbali smo se, a je ves ta naš strah bil brez prave potrebe, kajti še eden se ni nas dotaknil, nihče nas ni ranil, pač pa veselo so mahali $\mathrm{z}$ repi, $\mathrm{z}$ dobrikanjem krotkim spremljali naše korake, dokler nas služabnice v dvorcu niso sprejele, nas vseh odpeljale po marmorni veži k svoji gospe, ki v lepi dvorani na vzvišenem stolu $\mathrm{v}$ svetli je halji ogrnjena z zlato tančico sedela. 
Nimfe, ob njih nereide bile so z njo skupaj v dvorani, vendar pa niso ne volne rahljale in tudi ne predle z urnimi svojimi prsti, razvrščale ene so trave, druge pa razne zeli in raztreseno cvetje po barvi skrbno prebirale, vse to so sproti pokladale v koške. Sama pa nadzorovala je njihovo delo, ker kakšna moč je $\mathrm{v}$ zeleh in kako jih je mešati treba, edina vedela je in zato prebrane je pregledovala. Vidi nas, mi jo pozdravimo, ona odvrne s pozdravom; zjasni se Kirkin obraz, kar znamenje dobro bilo je. Hitro je zdaj ukazala, naj zmešajo praženi ječmen $\mathrm{z}$ medom in $\mathrm{z}$ vinom krepilnim in s kislim usirjenim mlekom, $\mathrm{k}$ vsemu skrivaj pa dodala je sama še sladke sokove. Vzeli smo čaše, ki nudila nam jih je s sveto desnico. Ko smo na suha jih usta nagnili in žejni izpili, strašna boginja se vseh dotaknila je s šibo vrh glave. Sram me je, vendar povem: tedaj so po meni ščetine jele sršeče se ježiti in govoriti že tudi nisem več mogel, namesto besed sem krulil kot prašič. $\mathrm{V}$ tla se obraz je povesil in usta postala so rilec, vrat mi močno je nabrekel, z rokami pa, ki so še pravkar čašo držale, tedaj kar na lepem začel sem hoditi. Z drugimi, ki so taisto postali - kaj zmorejo čari! v hlev so me svinjski zaprli. Edini pa svinjske oblike ni dobil Evriloh, ker čaše ponujene vzel ni.

$\mathrm{Da}$, ko bi on ne odklonil, jaz sam bi še zdaj bil ščetinar, saj o toliki grozni nesreči od njega izvedel ne bi Uliks in ne bi prišel, maščevalec, do Kirke.

Njemu je dal mironosni Kilenijec cvet, ki bogovi molij mu pravijo, bel je, iz črnega vzklije korena. $S$ cvetom zaščiten in zraven zaščiten še $\mathrm{z}$ božjim napotkom stopil je v Kirkino hišo, odklonil zavratno pijačo, branil se, ko mu lase je hotela pogladiti s šibo, meč je potegnil in brž bojazljivko dodobra prestrašil. Desno nato sta si dala in dala besedo; Uliks je terjal tovariše zdaj nazaj kot poročno darilo. $\mathrm{S}$ sokom neznane rastline, a $\mathrm{z}$ boljšim, sedaj poškropi nas, švrkne po nas z zaobrnjeno šibo po glavi in druge, prejšnjim nasprotne uroke na koncu izreče nad nami. Dlje ko je čarala, bolj smo dvigali s tal se pokonci, parklji razklani na nogah izginili so in ščetine, spet smo dobili človeška ramena in lakte in roke. Ginjeni ginjenega smo nato Uliksa objeli, 
oklepajoč krog vratu ga, in drugega nič govorili nismo prej, dokler se nismo mu vsi iz srca zahvalili.

Pikova preobrazba $v$ detla; preobrazba njegovih spremljevalcev $v$ zveri; preobrazba njegove žene Kanente v zrak na kraju, poimenovanem po njej

Leto smo dni pomudili se tam; v tem dolgem obdobju mnogokaj videl sem, mnogo pa tudi ujel na ušesa. Slišal med drugim sem to, kar v zaupnem pomenku je rekla ena od dekel, katerih pri čarih imela je štiri.

Ko se mudil mi gospod je pri Kirki in sama bila je, bel in marmornat kip mi mladeniča šla je pokazat z detlom na glavi. Postavljen pa kip je bil v svetem prostoru, kjer je s premnogimi venci bil ves okrašen in ozaljšan. Kdo naj bi bil in zakaj ga v svetem poslopju častijo, vprašal sem ves radoveden, in kaj da še ptiča prenaša. »Čuj, Makarej, me in zraven pouči se, « to mi je rekla, »kolikšno moč ima moja gospa, pozorno poslušaj!«

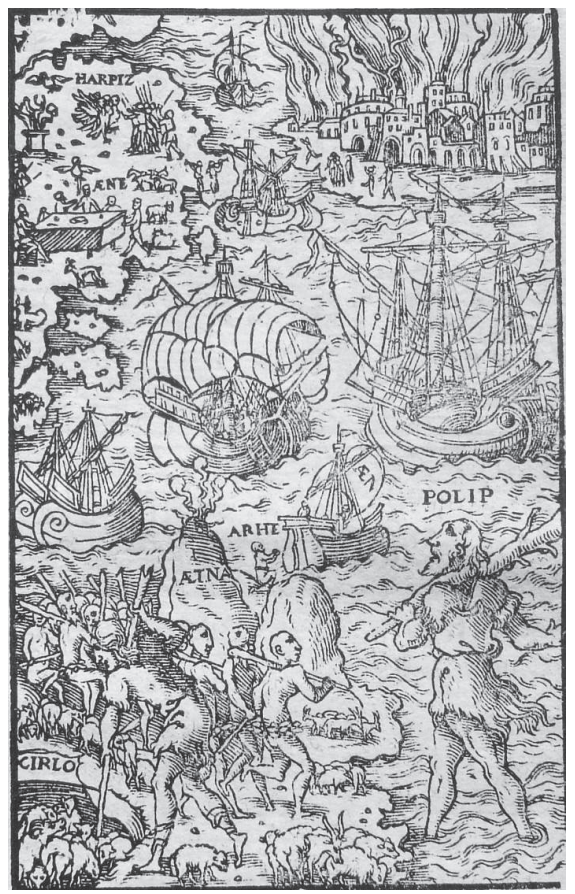

Slika 24: Circe Picum regem cupit (14.316-415) 
Pik Saturnov bil sin je in kralj v avzonski deželi,

s konji se vneto je bavil, z živalmi, koristnimi v vojni.

Tak, kot ga vidiš, je bil. Le oglej si njegovo lepoto,

po upodobljeni v kipu lahko si resnično predstavljaš.

Duh je enak bil zunanjosti; ni pa še štirikrat mogel

videti iger, ki vsakih pet let so v Elidi grški.

Nase pritegnil oči vseh driad je po latijskih gorah,

njega bi rade imele povodne boginje, najade,

kar jih prebivalo v reki je Albuli, kar v Anienu,

v Numiku, v kratko tekočem Almonu in v Narvu deročem

z onimi, ki so živele še v Farfara temnih valovih,

dalje še, kar jih bilo po gozdovih je skitske Diane

ali po jezerih bližnjih. A on vse te je odklonil,

ljubil le nimfo je, ki jo baje Venilija nekdaj

Janu pravičnemu na palatinskem je griču rodila.

Ko dozorela je v leta, da čas je prišel za možitev,

Pika v Lavrentu od vseh so izbrali in njemu jo dali.

Lepa bila je izredno, izredno izvežbana v petju, dali zato so Kanenta ime ji, saj s svojim je glasom

drevje in skale premikala, divje živali krotila,

dolge ustavljala reke je v toku in ptice med letom.

Ko pa prepevala z glasom dekliškim je nekega dneva,

Pik iz dvorca odšel je na polje lavrentsko, da tamkaj

vepra lovil bi. Prijezdil na iskrem je konju in v levi

dvoje je kopij imel, v lep plašč škrlatni ogrnjen,

spet pod vratom $\mathrm{z}$ zaponko iz same rumene zlatnine.

V iste gozdove prišla tudi Sončeva hči je nabirat tam po gričevju, bogatem $\mathrm{z}$ zelenjem, si nova zelišča.

Svoja kirkejska je polja, z imenom po njej, zapustila.

Skrita v grmičju je mladca zaznala, ob njem ostrmela -

vsa nabrana zelišča ob tem so iz rok ji zletela,

hkrati bilo ji je, kot da vnel bi se bil ji ves mozeg.

Brž ko je k sebi prišla in je prva vročica minila,

kaj si želi, bi povedala rada, a k njemu ni mogla,

ker je prehiter bil konj in bilo preveliko je spremstvo.

»Vendar ne uideš mi, « rekla je, »tudi, če nosi te veter,

če se poznam in če ni iz zelišč vsa moč izpuhtela,

da, če zagovori moji čarovniški še kaj veljajo!«

$S$ temi besedami že je na videz pričarala vepra,

dala ukaz, naj drvi, da bi videl ga kralj, in naj plane,

kakor resnično bi v gosto se hosto zagnal, kjer je največ

drevja in ni nikakor mogoče, da konj bi prodrl.

Pik ni slutil utvare, takoj se podal je za plenom, 
konja spotil, mu s hrbta sestopil, nato pa zablodil peš po visoki podrasti, sledeč le varljivemu upu. Kirka molila je, zraven mrmrala čarovne besede, boštva neznana rotila $\mathrm{z}$ neznanim urokom, $\mathrm{s}$ katerim Luni zakrivala beli obraz je in mogla je tudi z njim pod očetovo glavo navleči deževne oblake. Brž ko izreče urok, se na nebu zgostijo oblaki. Zemlja megle je hlapela, da spremstvo je s tavanjem v mraku zgubljalo smer po temi in kralj ostal je brez straže. Kirka izrabi trenutek in kraj: »Pri tvojih očeh, ki moje ujele so, zraven, krasotec, pri tvoji lepoti prosim ponižno, boginja sem, mojo ljubezen usliši, sprejmi za tasta si Sonce, ki vsepovsod vsakega vidi, daj, ne zavrzi nikar trdosrčno Titanide Kirke!« To mu je rekla, a on jo ves divji takole zavrne: »Bodi kdorkoli, « je rekel, »a tvoj ne bom, osvojila druga me je in ima me in rad bi, da dolgo bi njen bil. $\mathrm{Z}$ drugo ljubeznijo dane zvestobe nikdar ne prelomim, dokler usoda ohrani mi Janovo hčerko Kanento!« Ko je Titanija večkrat zaman poskusila s prošnjo, »Nekaznovan ne ostaneš, « je rekla, »in tudi h Kanenti več te ne bo! Spoznaj, kaj užaljena v svoji ljubezni more napraviti ženska! In taka in to sem jaz, Kirka!« Dvakrat nato na zahod se obrne in dvakrat na vzhod še, trikrat je mladca ošvrknila s šibo in trikrat urekla. Pik je bežal in čudil sam sebi se, kaj da hitreje kakor sicer gre; naenkrat je perje opazil na sebi: zdražen, ker latijski gozd dobil z njim novo je ptico, kljuvati s trdim je kljunom začel po drevesih surovih, dolbel in rane zadajal je širno raztegnjenim vejam. Perje njegovo dobilo je plašča škrlatnega barvo, kar pa zaponka je zlata bilo, da si plašč je zapenjal, puh je postalo in prav kot zlato je obrobljalo tilnik. Piku nič prejšnjega več ni ostalo - z izjemo imena.

Ko spremljevalci zaman so po polju za Pikom klicali, ne da bi kje ga odkrili, so tam naleteli na Kirko. Zjasnila ta čas bila že ozračje je in dovolila soncu in vetrom, da z zemlje so vso meglo prepodili.

Njo po pravici dolžili so krivde, zahtevali kralja, s silo pretili, hoteč jo napasti z okrutnim orožjem. Kirka s pogubnim je strupom in s čarnim jih sokom oblila, Noč in bogove Noči je iz Ereba in iz podzemlja 
sklicala, Hekato samo pa z dolgimi vzkriki prosila.

$\mathrm{Z}$ mesta - kar čudno je reči - se gozd naenkrat premakne, tla zaječala so, drevje v bližini je vse pobledelo, trava vsa rosna bila od krvi je, po njej poškropljene, kamenje, kakor se zdelo je, zdaj je zamolklo bobnelo, vtis je nastal, da lajajo psi; obenem po zemlji črnih je kač mrgolelo, letele so duše pokojnih. Spremstvo, s čudesi prevzeto, vzdrhti; ko tako trepetajo, $s$ šibo strupeno se ona dotakne osuplih obrazov. Mladci ob tem so dotiku v različne pošastne zverine vsi spremenili se, nihče ohranil ni svoje podobe.

Zahajajoči že Fojb je obseval tarteško obalo, vendar Kanenta zaman še moža je $z$ očmi in pa s srcem pričakovala. Strežaji in posli so šli po gozdovih, s sabo so kralju naproti nosili prižgane svetilke. Jokati in si puliti Iase in se biti po prsih nimfi, ki vse to je delala, ni še dovolj bilo, z doma v latijska polja je šla in po njih kot iz uma blodila. Šest jo noči in toliko tudi, ko vstali so, dnevov videlo je onemoglo brez spanja in hrane hoditi preko gora in dolin, tako, kot slučaj jo je vodil. Zadnji jo Tiber je videl od žalosti in potovanja trudno, ko tam na njegovem je dolgem počivala bregu. Tam je s solzami besede prelivala v mile napeve, ki jih nesrečni ubirala sama je žalost, kot včasih tik pred smrtjo labod si poslednjo je pesem zapela. Ko se naposled od žalosti mozeg je mehki raztopil, ginila je in polagoma v zrak je lahkotni splahnela. Zgodba o tem pa ostala je v kraju, ki stare Kamene z vso pravico po nimfi so rekle odslej mu Kanenta. -

Takega praviti mnogo sem slišal in mnogo sem videl v letu, ki dolgo bilo je. Od tam spočiti in leni morali končno smo zopet na morje in zopet za vesla: vožnjo nevarno in dolgo je pot in morje viharno Kirka tedaj napovedala. Zdaj vam odkrito priznavam, jaz sem se bal in ko to smo dosegli obalo, ostal sem.« 
Preobrazba Diomedovih tovarišev v ptice

To Makarej je povedal. Dojiljo Enejevo v žari

marmorni dali so v zemljo s tem kratkim napisom nad grobom:

»TU JE KAJETO, KO REŠIL ME JE IZ ARGOLSKEGA OGNJA

Z ZNANO LJUBEZNIJO, KOT SE SPODOBI, REJENEC UPEPELIL. «

Vrv so nato v pristanišču odvezali in so odpluli, daleč pustili zasede in dom so zloglasne boginje, jadrali v kraje, kjer Tiber v mrakotni se senci izliva $\mathrm{v}$ morje in s sabo prinaša $\mathrm{z}$ valovi vanj pesek rumeni. Favna sinu, Latina, dobil je tam dvorec in hčerko, ne brez boja. $Z$ divjaškim plemenom začeli so vojno,

Turn je ves pobesnel, ko mu tast je odrekel nevesto.

Vsa je Tirenija v Latij udarila, dolgo se bila huda je bitka z orožjem zelo razburljivo za zmago. Vsak od obeh si še s tujimi četami moč je pomnožil, mnogo jih Rutulom, mnogo Trojancem prišlo na pomoč je. Ni Enej zaman odšel na prag bil k Evandru, pač pa zaman k Diomedu priseljencu v mesto njegovo Venul je šel. Diomed pod Japigom je Davnom bil namreč mesto veliko si zgradil in zraven ozemlje priženil. Ko naročilo mu Turnovo Venul sporočil je s prošnjo, da bi pomagal, ajtolski junak mu pomoč je odrekel, češ da ne on in ne tastovo ljudstvo ne marajo bojev, svojih ljudi pa da nima, da $\mathrm{z}$ njimi bi šel pod orožje. »Vendar ne misli, da vse to izmislil sem si, «mu je rekel. "Dasi ob bridkem spominu se žalost mi le še obnavlja, vse bom povedal. Ko Ilion bil je visoki zažgan že, ko pred danajskim je ognjem že Pergam drhtel in se tresel, kazen, ki sam jo zaslužil narikski junak je, ko vzel je devo Devici, na vse je Danajce priklical, da veter nas razkropljene je gnal prek sovražnih valov in čutili $\mathrm{v}$ noči med bliski in dežjem smo jezo neba in srd morja, zlasti pa ob Kafereju, kjer višek je vse bil nesreče.

Žalostnih zgodb vam sedajle po vrsti ne bom več našteval: z Grčijo Priam še sam takrat čustvovati bi moral. Mene je skrb bojevite Minerve rešila iz morja, vendar pa spet iz domače dežele sem moral, ker rane Venera stare se spomnila je in me brž kaznovala. Take težave na morju prestal sem in take na kopnem, kjer sem se moral boriti, da večkrat naglas blagroval sem 
vse, ki isti neznanski vihar jih je v morje pogreznil

ob Kafereju, za vse nedostopnem, in večkrat sem želel

samemu sebi, da hkrati bi z njimi takrat se potopil.

Ko so prestali tovariši bojev in morske gladine skrajno nevarnost, omagali so in prosili, da konec bil bi že blodenj. Tedaj ognjeviti je Akmon, razkačen spričo nesreč, spregovoril: »Kaj neki je sploh še ostalo, česar ne boste prestali, junaki? Le kaj naj Kiterka sploh še stori, če že hoče? Še vedno je prostor za rano, dokler bojimo se hujšega: ko pa najhujše prestaneš, strah pod nogami je, varen pred vsakim in slehernim zlom si. Kar naj me sliši in kar naj sovraži, pa ne samo mene, vse z Diomedom! Resnično, kaj mar nam je njeno sovraštvo, drago dovolj nas in dosti je stalo že lastno bahaštvo!«

S takimi govori dražil je Venero in jo izzival Akmon Plevronijec, staro ji jezo je z njimi obujal. Redki so dali mu prav, prijatelji drugi smo v glavnem raje svarili ga. V hipu, ko v ustih imel je odgovor, stanjšal se vrat mu in glas je, lasje so se v puh spremenili, puh, ki novi mu vrat je in prsi in hrbet pokrival. Roke njegove ob tem so večja peresa dobile, lakti upognjeni v hipu postali so lahke peruti, prsti zavzeli so velik del nog, a usta strdila v kljun so roženi se; ta se v konico je šilasto zožil. Lik in Idas tedaj in Reksénor in Niktej in Abas vsi se začudijo; v svojem začudenju hkrati še sami isto podobo prevzamejo. S tem je od nas odletelo večje število posadke, ki zdaj je ob veslih letela. Vprašal me boš morda po vrsti teh ptičev nenadnih: niso labodi, a vendar podobni so belim labodom. Vidiš, zato zdaj komaj to mesto in suho ozemlje

Davna Japiga kot zet s preostalimi svojimi branim.«

\section{Preobrazba apulskega pastirja $v$ divjo oljko}

To Diomed je povedal. Nato kalidonsko kraljestvo, luko pevketsko in polja mesapska zapustil je Venul. Tam je videl votlino, kjer v senci obilnega drevja sredi trstičja lahko nihajočega Pan kozonogi dom si izbral je. Nekoč tudi nimfe živele so tamkaj. 
Lepega dne jih prestraši apulski pastir; pobegnile brž so pred njim, a ko prvi se strah je plašljivkam polegel, $\mathrm{k}$ sebi so zopet prišle, prezir pokazale plašljivcu, rajale lahkih so nog naokrog po ubranem napevu.

Grajal je nimfe pastir, oponašal jih z divjim skakanjem, hkrati po rovtarsko s spolzko besedo od daleč jih zmerjal, vse dokler grlo umazano ni mu v drevo otrdelo. Zdaj je drevo in po soku spoznaš njegovo naravo. Kakšen je jezik imel, oleastrove jagode grenke kažejo: vanje prešla je besed njegovih grenkoba.

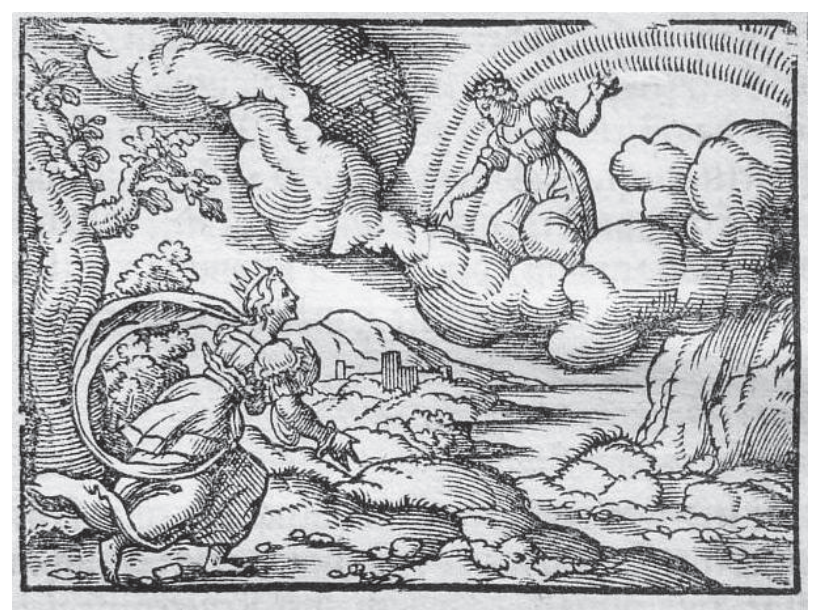

Slika 25: Apulus, pastor procax (14.511-526)

\section{Preobrazba Enejevih ladij v morske nimfe}

Ko so od tam vrnili se sli z vestjo, da ne pride vojska ajtolska, so brez pomoči in kar sami Rutulci vojno vodili. Oboji krvi so veliko prelili.

Turn naposled goreče je bakle do ladij prinesel, ognja so zbali se ti, ki jim prej prizaneslo je morje. Smolo in vosek in drugo netivo je ogenj použival, šel po visokem je jamboru $\mathrm{k}$ jadrom in že se kadil je ladje ukrivljene krov, ko spomni na lepem se sveta mati bogov, da zgrajene so ladje iz smrek, ki na Idi prej jih nekdo je posekal, na gori Kibelini; v hipu v zrak se razlegel žvenket je medi in piskanje svireli, s krotkimi levi po lahnem se zraku je tja odpeljala. »Turn, zaman z bogoskrunsko desnico zažigaš, « je rekla, 
»ladje rešila bom; ne, ne pustim, da jih ogenj požrešni

zdaj uniči, saj deli in udje iz mojih so gajev."

To je rekla boginja. Nato zagrmi in po gromu pride še toča, ki skače po tleh, za njo pa še ploha.

$Z$ vpadom nenadnim sinovi Astrajevi zrak so in morje zgibali; vsi so se gnali in vsi so posegali v bitko.

Enega samega moč porabila je mati dobrotna,

z njim je pretrgala frigijskim ladjam vrvi iz prediva, gnala naprej jih in sredi morja jih vse potopila.

Les se zmehčal je in bruna so v vodi postala telesa, glav obliko dobile tedaj so ukrivljene krme,

vesla so v prste in noge se plovne na mah spremenila.

Kar pa so boki bili, so boki ostali, a gredlji

$\mathrm{v}$ ladij notranjosti so preobličili se v hrbtenice, jadra razvila so v voljne lase se, rajne pa v roke; sinja kot prej jim ostala je barva in, kakor plašile prej so valov se, veselo po njih so kot morske najade potlej zarajale. Dasi iz skalnatih gorskih višav so, v morju mehkobnem prebivajo, ne da bi kaj jih motilo, kje so doma. A vendarle niso povsem pozabile, koliko že so prestale na morju viharnem, zato pa večkrat $\mathrm{z}$ rokami podprle so ladje, ki val jih je nagnil, če so le take bile, da niso vozile Ahajcev.

$\mathrm{V}$ mislih poraz jim je frigijski, $v$ srcu črtijo Pelazge; $\mathrm{Z}$ vedrim obrazom razbito so gledale ladjo neritsko, gledale vse so vesele, ko ladja postala je skala.

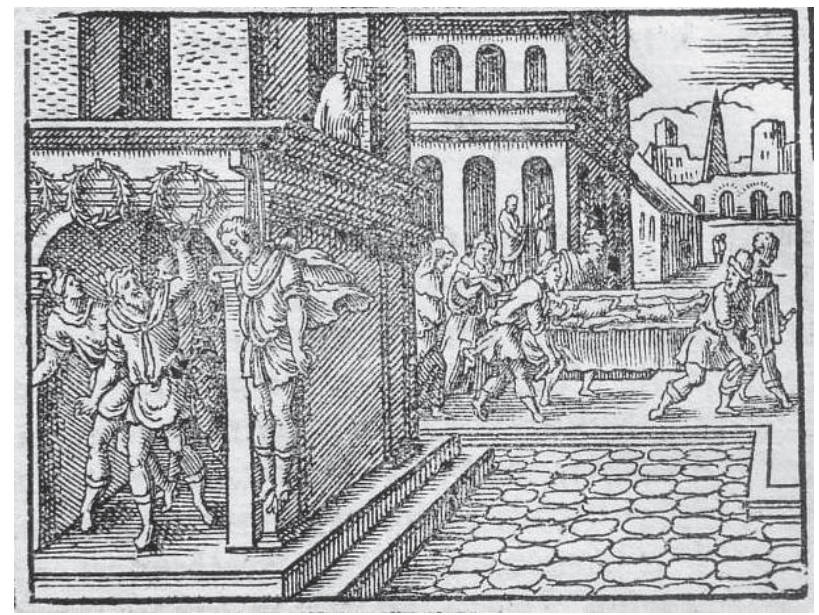

Slika 26: Turnus naves incendit (14.527-565) 


\section{Preobrazba mesta Ardeje v čapljo}

To, da so ladje tako oživele in nimfe postale, up je budilo, da v strahu Rutulec bo z bojem prenehal. Turn pa je vztrajal. Bogove, pogum, ima vsak v tem spopadu, ne za doto in ne za kraljestvo in tastovo žezlo, ne za nevesto Lavinijo, temveč za zmago, zato jih sram je bilo prenehati, sram odložiti orožje. Končno je Venera videla zmagati svojega sina, Turn pa je padel - in padla je Ardeja, mesto mogočno, v času, ko bil je še živ. Potem ko dardanski jo ogenj vso je sežgal in domove še topli pepel je pokrival, iz razvalin se je dvignila ptica, dotlej nepoznana, tolkla je $s$ krili in z njimi otresala s sebe pepel je. Mršavost, glas in boječnost in vse, kar opaziti moreš v mestu zavzetem, in tudi ime ji je mesta ostalo: s tleskanjem svojih peruti kot ardea sama žaluje.

\section{Preobrazba Eneja v boga}

Hrabrost Enejeva vse je bogove in z njimi Junono spravila; glej, pozabili vsi končno na staro so jezo. Jul je odraščal, Enej mu je dobro utrdil kraljestvo, čas je dozorel, kiterski junak je bil zrel za nebesa. Venera vse je bogove obšla in objela očeta, rekla je: »Nikdar mi nisi ničesar odrekel, moj oče, bodi še zdaj mi naklonjen po svojih močeh, to te prosim. Mojemu sinu Eneju, ki ded si po moji mu krvi, milosten čast daj božansko, pa tudi če majhna bila bi, le da jo daš mu. Dovolj je, da enkrat neljubo kraljestvo videl je in pa da enkrat v podzemlju že šel je prek Stiksa!« Prošnjo bogovi uslišijo, tudi Junona ostala ni neprijazna, s prijaznim obrazom ji je pritrdila, oče pa: » $\mathrm{Ti}$, ki me prosiš, in on, za katerega prosiš, vredna daru sta nebeškega. Prejmi zdaj, hčerka, kar hočeš!« To je dejal. Vesela se je zahvalila očetu, vpregla golobe in brž po ozračju se proč odpeljala proti lavrentski obali, kjer skrit med trstičjem se vije Numik in v bližnje se morje narasel vali in izliva. Temu ukaže, naj vse, kar je smrti zapadlo, z Eneja splakne in tiho tekoč odnese tja v morsko globino. Venerin brž je ukaz rogovilež izpolnil in $\mathrm{z}$ vodo 
vsega, kar smrtno bilo je, opral in očistil Eneja, kar pa najboljši, nesmrtni bil del je, le to je ostalo. Truplo očiščeno mati z božanskim je vonjem natrla, ust dotaknila $\mathrm{z}$ ambrozijo se, ki ji v zmesi dodala sladki je nektar, da bog je postal. Nato narod Kvirinov templje $z$ oltarji mu dal je in Indiget dal mu ime je.

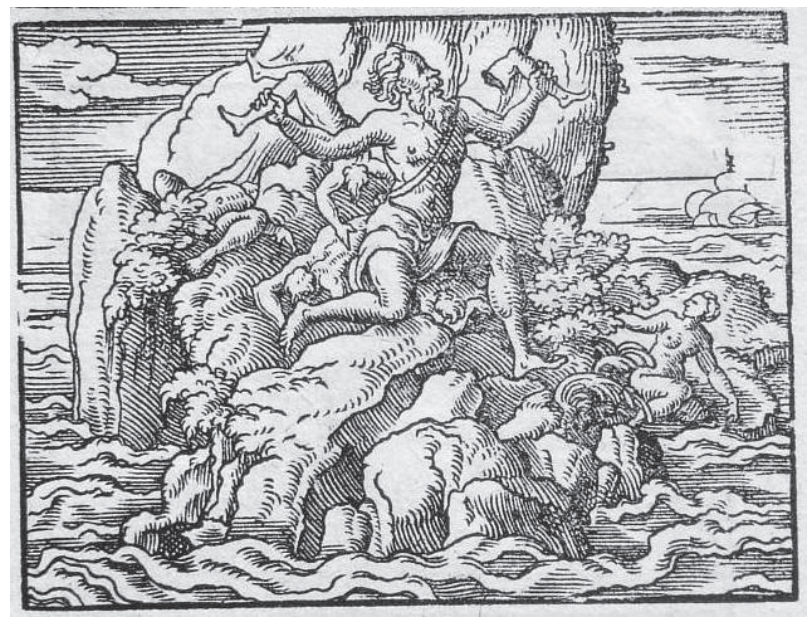

Slika 27: Apotheosis Aeneae (14.581-608)

\section{Preobrazba Vertumna $v$ starko}

Potlej nad Albo in zemljo latinsko dvoimni Askanij vladal je. Njemu je Silvij sledil, a za njim je pridobil žezlo si staro Latin, njegov sin, ki ime je obnovil. Epit je slavni prišel za Latinom, za njim pa bila sta Kapet in Kapis vladarja; od teh je Kapis bil prvi. Potlej od njiju dobil Tiberin je svoje kraljestvo, Tiberi, reki etrurski, v kateri je slednjič utonil, svoje ime je dal. Remul in Akrota hrabri njegova sina bila sta. Starejšega, Remula, s svojim udarcem strela ubila je - sam po značaju bil tak je kot strela. Akrota, zmernejši brat njegov, je žezlo vladarsko hrabremu dal Aventinu, ki v grobu na istem je griču, kjer kraljeval je, in grič se po njem še zdaj imenuje. Potlej pod Prokovo vlado bilo palatinsko je ljudstvo. 
V času, ko on je bil kralj, je skrbna Pomona živela, skrbneje kakor vse hamadriade latinske je vrte obdelovala in tudi nobena tako ni gojila sadnega drevja, po čemer ime je dobila. Ljubila ni ne gozdov in ne rek, le grudo in drevje, ki sadje sočno rodi. Ne kopja, rezač je ukrivljen imela, divje poganjke in veje pregoste je obrezovala, v skorjo razklano cepila drevesa, da vlila so sok svoj tujim mladikam, ki dala Pomona jih v nove je špranje. Zraven, da teh korenik, ki srkajo vlago hranilno, žejalo ne bi, je skrčena vlakna zalivala $\mathrm{z}$ vodo. To jo zanimalo je, le to veselilo in želje ni po ljubezni imela nobene. Boječ se nasilja svoje nasade zapira, v njih moškim skrivaj se ogiblje. Česa le satiri mladi, ki plešejo spretno in radi, niso storili in pani, ki s smrečjem roge so ovili, Silvan, ki s svojimi leti se znova in znova pomlaja, dalje še bog, ki tatove straši s spolovilom in srpom, v želji, da njo bi dobili! V ljubezni jih vendar prekašal vse je Vertumen, a nič ni, prav nič ni srečnejši od njih bil. Kolikokrat le, oblečen po kmečko kot žanjec, je v košu klasje prenašal na hrbtu; zares je bil čisto kot žanjec! Večkrat mu tudi v laseh je mrva še sveža ostala, kakor bi travo kosil in nato pokošeno raztrosil. Večkrat še ostne je v žuljavi roki obdržal, kot pravkar - to bi prisegel - utrujene bil bi voliče izpregel. »Obrezoval je trte, «bi menil, ko krivec imel je, kadar je lestev pristavil, bi menil: »Obiral bo sadje.« $\mathrm{Z}$ mečem vojak je bil, s trnkom na palici bil je kot ribič. $\mathrm{V}$ raznih podobah tako neovirano večkrat k Pomoni mogel je priti, da užival z očmi je njeno lepoto. Čepico pisano nekega dne si dal je na glavo, sive lase si privzel, se na palico zraven opiral, kakor bi stara ženica bil. Stopil v obdelani vrt je, čudil se jabolkom lepim in rekel: »A ti si še lepša!« Hvalil jo še je in še, jo poljubljal, kot nikdar tako je starka ne mogla bi. Sključen na tleh nato obsedel je, gledal na veje, ki k tlom se krivijo pod sadjem jesenskim.

Brest je nasproti tam lep bil, ovešen $\mathrm{z}$ bleščečim se grozdjem; ta okras je pohvalil in potlej še trdnost njegovo.

»Vendar, « je rekel, »če tukajle brest bi kar sam stal brez trte, nič razen listja imel ne bi, s čimer Ijudi bi privabljal. 
Trta podobno, ki vzpenja ob brestu se zdaj in drži ga; da, če bi združena z njim ne bila, bi na tleh obležala. Ti ob drevesu se tem ne zgleduješ, ko ni za združitev nič ti mar, o zakonu ne čuti ne misliti nočeš. Da le hotela bi! Helena toliko ne bi imela snubcev, ne ta, ki je vzrok bila za vojno z Lapiti, niti ne žena Uliksa, ki bil je oprezen, a drzen. Tudi sedaj, ko pred snubci bežiš in jih vedno odklanjaš, tisoč te moških želi, polbogovi žele te, bogovi, sploh te žele, kar skriva bogov se v Albanskem gorovju. Toda če modro pomisliš, če zdaj bi dobro hotela vezati se in poslušati starko, ki bolj kot vsi drugi, bolj, kot si misliš, te ljubim - zavrni vse snubce navadne, vzemi Vertumna za druga zakonskega. Pôrok sem jaz zanj, saj niti sam se tako ne pozna, kot ga jaz. Ta ne klati nič se okoli po svetu in tudi velikih posestev 680 ne obdeluje in v vsako, ki vidi jo, se ne zaljubi kakor večina mladeničev drugih. Ti prvi in zadnji plamen njegov boš, le tebi bo svoje življenje posvetil. Hkrati še vedi, da mlad je, da lep je po svoji naravi, vendar pa tudi lahko se v vse spreminja oblike. Kar mu ukažeš, postane - in vse boš lahko ukazala. Isti konjiček imata, oba vaju sadje zanima; nima v desnici kdaj tvojih darov, vesel, ker so tvoji? Toda sedaj ne želi niti sadja, ki trgaš ga z drevja, niti zelišč s prijetnim okusom, ki v vrtu gojiš jih, niti kaj drugega kakor le tebe. Usmili se torej njega, ki zate plamti; kar hoče, to prosi po meni. Boj maščevalnih bogov se in boj se Ramnuside srda, spomni Idalijke se trdosrčne, ki v prsih sovraži! Da pa še bolj se boš bala, povem naj - saj v dolgem življenju mnogo sem slišala - zgodbo, ki dobro je znana na Kipru, ta te morda omehča, morda se naposled ukloniš. 


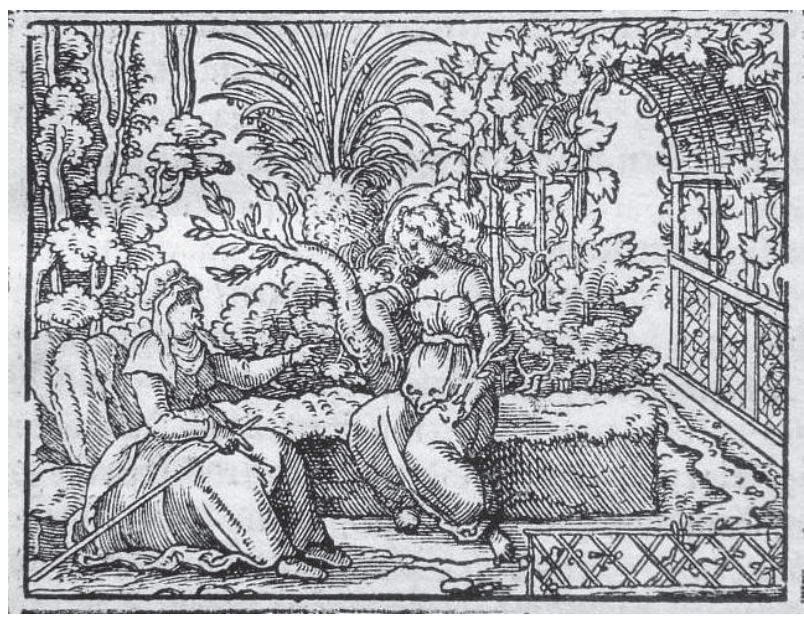

Slika 28: Pomona et Vertumnus (14.621-697)

\section{Preobrazba Anaksarete v skalo}

Anaksareto, ki starega Tevkra bila plemenita hči je, ugledal je Ifis, rojen iz preproste družine. Videl jo je in do mozga v kosteh se je vanjo zaljubil.

Dolgo boril se je, vendar strasti ni premagati mogel s pametjo; šel je ponižno zato do njenega praga, tam razodel je dojilji nesrečno ljubezen in prosil, naj mu ne bo neprijazna, ko upa na njeno rejenko.

Drugič se spet je dobrikal služabnicam, vsako med njimi prosil je z glasom rotečim, naj prošnjam njegovim pomaga; večkrat jim pisma ljubezenska dal je, da njej bi jih nesle. Včasih podboje ovesil je $\mathrm{z}$ venci, ki prej jih je $\mathrm{z}$ roso solz poškropil, a sam kar na trdi se prag je ulegel, žalosten ves in nevoljen je grajal zapahnjena vrata.

Ona je hujša bila kot razburkano morje, ko Kozla toneta, trša kot jeklo, ki noriški ogenj topi ga, trša od skale, ki v zemlji tiči globoko vsajena: zgolj zaničljiv nasmeh je dobil, prevzetna mladenka s svojo oholo besedo zaljubljencu up je jemala. Bridkega zbadanja Ifis ni več prenašati mogel, zadnje besede v slovo je izrekel pred njenimi vrati: »Anaksareta, glej, zmagala si, ne bo ti več treba moje prenašati zoprnosti. Triumfiraj veselo, kliči Pajana in zdaj z lovoriko se svetlo ovenčaj! Zmagala si, radovoljno umrem, raduj se, okrutna! 
Nekaj bo le, da hvaliti boš morala mojo ljubezen, ker ti ugodil sem, boš pač priznala to mojo zaslugo. Vedi pa, moja ljubezen do tebe nič prej ne preneha kakor to moje življenje, oboje bom hkrati pogrešil. K tebi ne bo prišel glas, ki o smrti bi moji ti pravil, sam bom, verjemi, kar sam bom prišel in obstal bom pred tabo, krute oči boš lahko napasla na mrtvem telesu. Vi pa, bogovi, če gledate kaj na človeška dejanja, mene se spomnite - drugega jezik ne more prositi dajte, da glas bo o meni ostal, in zraven še, kar ste vzeli življenja mi, mojemu dajte živeti spominu!« To je dejal. Na podboje, ki večkrat krasil jih je z venci, vlažne oči je uprl in roke privzdignil je bele, potlej pa, ko iz vrvi nad vrati napravil je zanko, rekel je še: »Ti všeč bo ta venec, hudobnica kruta? « Vtaknil si glavo je v zanko, še vedno je k njej bil obrnjen; težko telo je nesrečno z zadrgnjenim grlom viselo. Noge so suvale v vrata, da tresla so se in bobnela, kakor bi bala se; brž ko odprli so jih, so izdala, kaj se zgodilo je. Posli so kriknili in, ko zaman so sneli ga, nesli so materi truplo (ker oče je padel).

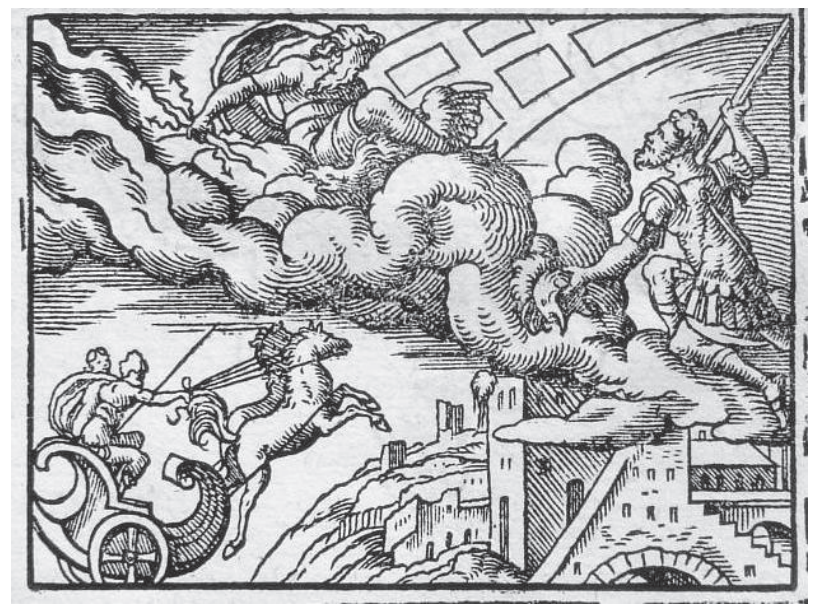

Slika 29: Iphis et Anaxarete (14.698-764)

Mati ga vzela je v svoje naročje; ko mrzlo telo je svojega sina objela, nad njim je tožila z besedo žalostnih staršev - in žalostnih mater opravila delo. Solzna sprevod je pogrebni vodila po mestu, ko nesli bledorumeno so truplo sežgat na pogrebni grmadi. 
Pot, po kateri pomikal sprevod se je žalni, slučajno mimo je hiše šla Anaksaretine. V njej trdosrčna slišala je žalovanje - in bog se nad njo maščeval je.

»Dajmo, poglejmo si žalni sprevod, « je ganjeno rekla, v sobo visoko odšla, ki imela široka je okna.

Toliko da na nosilih je videla Ifisa, že so steklo postale oči ji, vsa kri ji je šla iz telesa, to pobledelo je; skušala stran zaman je stopiti, noge so kar obtičale, ko stran bi se rada ozrla, tudi tega ni več mogla. Polagoma vsi so ji udje kamen postali, ki prej ga že v trdih je prsih imela. Vedi, da to ni izmišljena pravljica, njena podoba danes še hrani kot kip v Salamini se v templju $\mathrm{z}$ imenom Venere Zavarovalke. Zapomni si, nimfa, kar pravim, prosim te, daj, nedostopnost opusti, z ljubimcem se združi! Mraz naj pomladni zato ne požge ti sadja v zarodku, niti naj ti ne otresejo hudi vetrovi že cvetja.«

Bog zaman je vse to govoril dekletu kot starka; zopet postal je mladenič, odložil navlako starosti, tak se nato je pokazal Pomoni osupli, ker bil je prav kot podoba bleščečega sonca, ko z neba prežene črne oblake in, kadar mu nič ni na poti, zasije. S silo jo hotel dobiti je, vendar je ni bilo treba; nimfo prevzela lepota boga je - boga je vzljubila.

\section{Preobrazba Romula in Hersilije v božanstvi}

Potlej nasilni Amulij Avzoniji vladal je z vojsko, dokler od vnukov ni Numitor stari dobil spet kraljestva, to je bil čas, ko je Rim nastal, na palilijski praznik. Tatij nato in sabinski očetje so vojno začeli, pot do gradu je odprla Tarpeja; nato pod orožjem, vrženim nanjo, izdihnila je, kaznovana pravično. Kurijci zdaj so neslišno in tiho kot divji volkovi sleherni šum zadržali in te, ki jih spanec prevzel je, speče napadli, pognali se k vratom zaprtim, ki trdno Ilijin sin jih zapahnil je. Ena je vendar odprla sama Saturnija, ne da v tečajih bi kaj zaškripalo. Venera, ta pa je slišala vrata, kako so zapahi padli na tla, in bi spet jih zaprla, a kaj, ko ni smela 
dela popravljati drugih božanstev. Najade avzonske v Jana bližini imele so dom ob mrzlem izviru.

Te za pomoč je prosila in nimfe boginjine prošnje niso odbile, ker kar je prosila, bilo je pravično.

Žile pri viru odprle so, vodo so ven izvabile, voda narasla pa $\mathrm{k}$ Janovim vratom ni vzela dostopa.

Žveplo rumeno nasule zato so v narasli studenec, v žilah pa votlih so smolo zažgale, da dim se je dvigal. V notranjost vrelca prodrla ob takih je sredstvih vročina, kar povzročilo je, da zaostajala nič ni za ognjem voda razgreta, ki prej tekmovala je z alpsko mrzloto. V šviganju ognja tedaj sta kadila oba se podboja, $\mathrm{k}$ vratom pa, ki so zaman se ponujala divjim Sabincem, nova je voda branila, dokler se ni Marsova vojska v boj podala. Ko z njo se postavil je Romul, pokrila rimsko so zemljo telesa Sabincev, ob njih pa telesa 800 rimska so zemljo domačo pokrila; v prepletu te bitke zetov in tastov se kri pomešala pod bridkim je mečem. Ne da bi vztrajali v bitki do konca, so nehali z boji, mir med seboj so sklenili in Tatij prevzel je vladarstvo.

Tatij nato je umrl in Romul obojemu ljudstvu dal je enake pravice. Tedaj je odložil čelado Mavors, tako je očeta bogov in ljudi nagovoril: »Čas je prišel, ko končno na temelju trdnem stoji zdaj rimska država, pa naj ji poslej kdorkoli že vlada. Meni in vrednemu vnuku izpolni obljubo z nagrado, kot napovedal si: vzemi ga $\mathrm{z}$ zemlje in daj na nebo ga! $\mathrm{V}$ zboru pred vsemi bogovi nekoč si mi rekel, kar pomnim, saj ljubeznive besede v hvaležnem sem srcu ohranil: 'Eden bo, ki ga v nebesne boš sinje višave prenesel.' To si mi rekel, zato sedaj, kar si rekel, izpolni!« Uslišal ga je vsemogočni, nebo je prevlekel z oblaki, z bliskom in s strelo in $\mathrm{z}$ gromom nato ves svet je prestrašil. Znamenje, da se izpolni mu dana obljuba nagrade, to je Gradivu bilo; opre se na kopje in skoči brž na voz z neustrašnimi konji pod jarmom krvavim, $\mathrm{z}$ bičem jih še priganja, ko spušča se $\mathrm{v}$ strmem poletu skozi ozračje na grič Palatin, zaraščen z drevesi. Ilije sina, ko vrnil je vse državljanske pravice svojim Kviritom, od tam je odnesel. Umrljivo telo je $\mathrm{v}$ redkem ozračju stopilo se, kakor svinčenka, iz prače 
sprožena močne, visoko pod nebom začne se topiti.

Lepo zunanjost in vrednejšo božjih blazin je dobil tam, tak je postal kot Kvirin, ko ogrnjen s kraljevskim je plaščem.

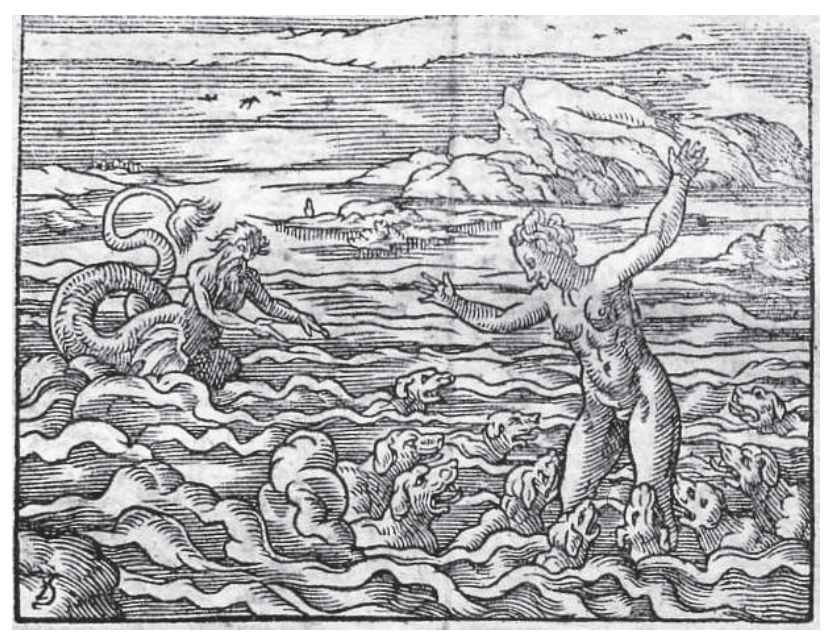

Slika 30: Romulus deus fit (14.805-828)

Žena jokala za njim je kot bil izgubljen bi, tedaj pa Iridi je ukazala kraljeva Junona, naj stopi brž po usločeni poti k Hersiliji, vdovi naj njeno tole pove sporočilo: »Gospa, ki okras si najlepši v zemlji latinski in v rodu sabinskem, ki vredna bila si takega najbolj moža prej, a zdaj si Kvirinova žena žalost opusti; če zdaj soproga bi videla rada, pojdi za mano v gozdič na zelenem Kvirinovem griču, kjer razprostira se senca nad rimskega kralja svetiščem." Iris boginjo uboga, po pisanem loku na zemljo brž je k Hersiliji šla, naročeno je vse izvršila.

Komaj Hersilija z vsem spoštovanjem se v njo je ozrla, rekla je: »O boginja - katera si, reči ne morem, vendar boginja si - pelji me, pelji in brž mi pokaži možev obraz. Če usoda nakloni mi, da bi ga mogla videti enkrat še, rekla bi, da sem dobila nebesa." Brž se s Tavmantovo hčerjo na Romulov grič je povzpela, tja pa tedaj se naenkrat iz etra je zvezda spustila, padla na zemljo, in glej, v bleščeči svetlobi te zvezde, v njenem so žaru Hersiliji vneli lasje se in z zvezdo skupaj odšli sta v ozračje. V domače roke jo graditelj rimskega mesta je vzel in prejšnje ime ji s telesom hkrati spremenil, zdaj Hora jo kliče in z njim je boginja. 


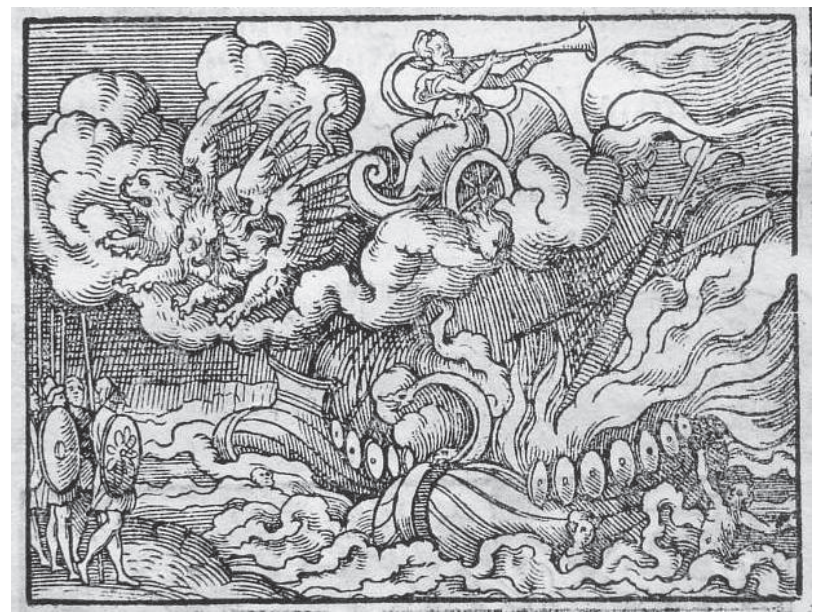

Slika 31: Hersilia, uxor Romuli, dea (14.829-851) 
Petnajsta knjiga

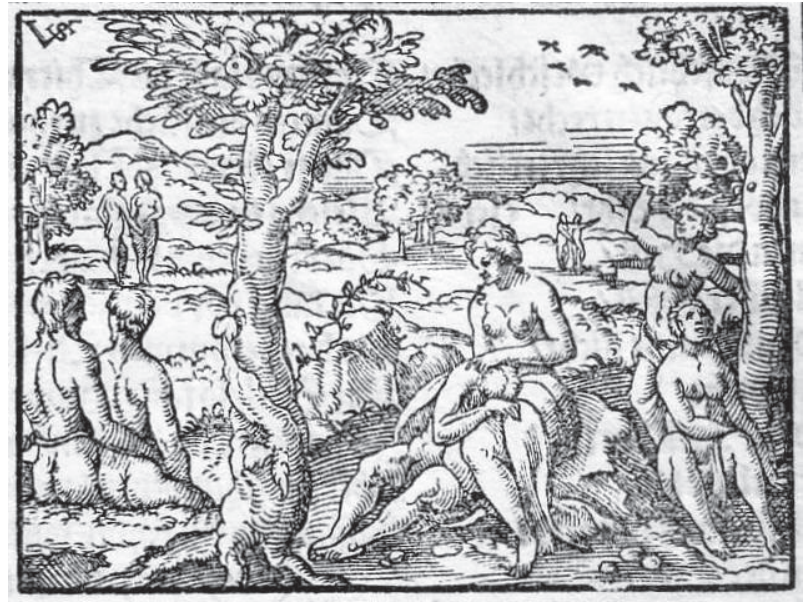

Slika 32: Aetas Numae regis (15.1-496)

\section{Miskel}

Vmes so ugibali, kdo naj pod tolikšno težo bremena vzdržal bi, kdo naj takšnega kralja postane naslednik. Fama, glasnica resnice, tedaj določila za kralja slavnega Numa je. Temu dovolj ni bilo, da poznal je šege sabinske, ne, $\mathrm{z}$ umom je bistrim vse više prodiral: raziskoval je, kaj neki bilo naj bi bistvo narave. Ta ga ljubezen je gnala, da dom je zapustil in Kure, v mesto, ki Herkula je gostoljubno sprejelo, odšel je. Ko je povprašal, kdo tam na obali italski postavil grško obzidje je, star domačin, ki poznal je preteklost, s svojo zgovornostjo vse mu natanko tako je povedal: »Pravijo, da je božanski sin Jupitrov od Okeana srčno prijadral k italski obali s hiberskim govedom. Ko se živina okoli po sočnati travi je pasla, sam v gostoljubno je hišo Krotónovo stopil in v njej se mirno spočil po dolgem naporu. Ko spet je odhajal, to je dejal: »Prav tukaj v tem kraju ob času bo vnukov mesto nastalo. "In ta napoved se res uresniči. Miskel je sin bil Argolca Alémona, bil je bogovom v svojem življenju posebno pri srcu, posebno priljubljen.

Nadenj nekoč se je sklonil, ko ležal v globokem je spanju, sam kijenosec in rekel mu: »Daj, domovino zapusti, 
pojdi in tja se preseli, kjer Ezar po kamenju teče.«

Zraven zagrozil je $\mathrm{z}$ mnogim in $\mathrm{s}$ strašnim, če ne bi poslušal.

Hkrati nato so izginile sanje in bog je izginil.

Sin Alémonov vstal je in tiho premišljal, kaj pravkar

videl je $\mathrm{v}$ snu, in potem se še dolgo sam $\mathrm{s}$ sabo boril je.

Bog je ukazal oditi, postava pa to je branila:

s smrtjo bi plačal, če hotel bi menjati kdo domovino.

Sonce sijajno se že v Okean potopilo je z glavo,

noč pa med gostimi zvezdami svojo je glavo zravnala:

zopet se isti mu bog je prikazal in isto zahteval,

zdaj pa še bolj in še s hujšim grozil je, če ne bi poslušal.

Zbal se je tega in hkrati razmišljal, kako bi prenesel

dedne svetinje v nov dom. Na lepem tedaj završalo v mestu je vsem, obtožili so ga, da prezira postave.

Ko so končali z zaslišanjem, krivdo brez prič potrdili, $\mathrm{v}$ capah obtoženi dvignil oči je in roke $\mathrm{k}$ bogovom. »O, « je zaklical, »junak, ki dobil do nebes si pravico $\mathrm{z}$ dvanajst napori, pomagaj mi, prosim, saj ti povzročitelj

moje si krivde! - Po stari navadi obtoženca nekdaj kamenček črn je obsodil, a bel ga oprostil je krivde. Tudi takrat se tako je vršila ta žalostna sodba: kamenček vsak, ki v nemilo se žaro je spustil, bil črn je. Ko pa iz žare so kamenčke stresli, da vse bi prešteli, vsi so bili se iz črnih obarvali v bele. Bog Herkul $\mathrm{v}$ sodbo tako je posegel in ta se je srečno končala: sin je Alémonov prost bil. Zahvalil za to se je bogu, spet ob ugodnih vetrovih odjadral na Jonsko je morje, plul ob Tarentu je lakedajmonskem in Sibaris, Neret pustil ob strani salentski, turinski zaliv in Krimiso, prav tako obalo Japigovo. Ko je objadral kraje obalne, je končno res našel določeno ustje Ezara reke in blizu ob njem še gomilo, v kateri zemlja že dolgo pokojne kosti je Krotonove krila. Tu napovedano mesto je Miskel nato ustanovil, dal mu po njem je ime, ki tu je nekoč pokopan bil.« To govori izročilo teh krajev, drži, da je takšen kraja in mesta začetek bil tam na obali italski. 


\section{Pitagora}

Mož je živel, Samošan po rodu, a hkrati zapustil

Samos je, $\mathrm{z}$ njim gospodarja in bil prostovoljno izgnanec,

ker je sovražil tiranstvo. In duh do bogov se mu vzpel je, dasi v nebesnih višavah prebivajo; to, kar narava skrila očem je človeškim, je s pametjo svojo doumel.

Kar pa $\mathrm{z}$ razumom in $\mathrm{z}$ raziskovanjem skrbno je proučil, drugim tolmačil je, krogu molčečih, ki občudovali nauk njegov so, razlagal izvir in začetek sveta je, vzroke in bistvo stvari, kaj bog je in kaj je narava, kaj so snegovi in bliski in strele in kdo res v oblakih ko se podijo, grmi, ali Jupiter ali vetrovi, zemljo kaj trese, po kakšnem zakonu se gibajo zvezde, to in še druge skrivnosti. On prvi je branil živali klati in jesti in prvi učena je usta odprl takšnemu nauku, čeprav besed vsi niso sprejeli:

»Nehajte vendar, ljudje, onečaščati svoja telesa s hrano zločinsko! Saj žito imate in sadje, ki z vej ga trgajte, $z$ vej obteženih, in grozdje nabreklo na trti; sladka zelišča imate in takšna, ki se omehčati, skuhati dajo na ognju! In mleka nihče vam ne brani niti medu ne, ki dušice materine ima vonj še. Zemlja razsipno bogastva in tečna hranila vam nudi, daje vam živeža, ne da bi klali in kri prelivali. $\mathrm{Z}$ mesom živali tešijo si lakoto; ne vse do zadnje, konji, govedo in zraven drobnica se pasejo s travo, tiste živali pa, ki po naravi so divje, srdite, tigri armenski in levi togotni in z volki medvedi, hranijo vedno se $\mathrm{z}$ mesom, se raje krvi veselijo. Kakšen zločin je to, da se z mesom meso napolnjuje, to, da požrešno telo debeli se s požrtnim telesom, to, da si človek ohranja življenje $\mathrm{z}$ ubojem živali!

Kaj, pri darovih, ki nudi jih zemlja, najboljša od mater, drugega nič ti ne prija, kot žvečiti s trdim zobovjem okrvavljeno meso in posnemati žrtje Kiklopov? Res ne moreš drugače $\mathrm{v}$ želodcu gladu utešiti, trebuh požrešni razvajeni vedno ubijati mora?

Tista davnina nekoč, ki zlata ji pravimo doba, srečna ob sadju bila je, z rastlinjem, ki zemlja ga daje, ne da kdaj si ljudje s krvjo bi oskrunjali usta. 
Varno tedaj spreletavale ptičje so jate se v zraku, zajec neustrašeno hodil in blodil med sočno je travo, 100 rib pa tudi ni gnala tedaj lahkovernost na trnek: vse je bilo brez zased in zvijač se nobenih ni balo, v miru popolnem živelo, dokler si ni neki nemarnež, kdorkoli že, ves nezadovoljen s to hrano, kot prvi z mesom živalskim pogoltno nekoč natrpal želodca. $\mathrm{S}$ tem utrl je pot grozodejstvu. Z ubojem živali prvič železo ugrelo se je, ko kri je škropila. To bi še šlo, ker ne da bi kaj zagrešili, priznavam, smemo ubiti žival, ki ogroža nam naše življenje. Smeli ubiti so jih - toda ne bi jih smeli pojesti.

Zlo pa nato se je širilo; svinji so bržkone prvi vzeli življenje, ker z rilcem zavitim posevke na njivah izpodkopavala je in letino dobro mendrala. Kozel je trto obgrizel in padel, zaklan, pred oltarjem Bakha, ki grehe maščuje, menda. S prestopkom je svojim škodil kar dvema. Le kaj zakrivile ste, ovce, ki mirne, $\mathrm{z}$ nektarjem, ki so ga vimena polna, nam dajete hrano, dajete mehko obleko, ki stkemo iz vaše jo volne niste kot žive koristnejše nam, ljudem, kot pa mrtve? Česa govedo, ki niti zahrbtno ni niti zvijačno, pač pa koristno in krotko, ustvarjeno zgolj za garanje, krivo bilo je? Samo nehvaležnež, darov, ki boginja daje jih, scela nevreden, je mogel izpreči živino, ki mu orala je, in jo zaklati; le takšen je mogel trudni, ker z njo je tolikrat trdo ledino prenavljal, spravljal z njo žetev, okrutno sekiro nad vrat zavihteti. Ni še dovolj, da greh se takšen dogaja, bogovom skušali ta so zločin podtakniti, češ, saj so vesela gornja božanstva zakola ob delu zgaranega vola. Žrtev brez hibe izberejo, žrtev najlepše postave škodi lepota ji taka; s trakovi ozaljšana, z zlatom, pred žrtvenikom stoji in nevedna posluša molitve, vidi, kako med roge položijo ji žito na čelo, žito, ki z njo je bilo pridobljeno, potem pa bo nože, te, ki jih v vodi je videla prej, s krvjo omočila. Živi še potlej iz prsi iztrgajo drob, ga motrijo, preiskovaje na njem, kaj vse so želeli bogovi. Kaj, da je tolikšna sla po zabranjeni hrani v človeku? Smrtniki, si jo res upate jesti? Ne, prosim, nikar ne delajte tega, po mojem svarilu se raje ravnajte! 
Kadar zaklano živino po kosih polagate v usta, vsak naj ve in začuti, da svoje najemnike žrete!

Bog mi usta odpira, po njem, ki navdihnjenje daje, verno ravnal se bom, Delfe odprl bom, svoja nebesa, vzvišenih misli oznanjal bom, vsem razodeval izreke, pojasnjeval bom skrivnosti, ki dolgo bile so neznane, um starodavnikov ni jih odkril. Do zvezd se povzpel bom, zemlje zapustil bom tla nepremična in plaval v oblaku, stopil na pleča mogočnega Atlasa, tam bom od daleč gledal ljudi, ki se klatijo kakor brez uma po svetu, trepetajoč, ker se smrti bojijo; vse te bom spodbujal, ko jim razlagal bom in raztolmačil, kaj pravzaprav smrt je.

Ljudstvo, ki scela te zmedel je strah pred smrtjo ledeno, kaj se Stiksa bojiš in teme in izmišljenih pravljic, pesniških tvorb, in nevarnosti v svetu, varljivo zlaganem? Naj na grmadi propade telo, naj vzame ga starost, nič ne misli, da zraven bi količkaj moglo trpeti. Duše nesmrtne so; vedno, ko prejšnje telo zapustijo, v drugo se vselijo, vseljene bivajo v njem in živijo. Jaz - še spominjam se - v času trojanske sem vojne bil Evforb,

Pantojev sin, ki Atrida mi mlajšega sulica silna nekega dne obtičala je v prsih, obrnjenih k njemu. Ščit, ki v levici sem svoji ga nosil, nedavno sem videl v templju Junoninem, tam v deželi Abantovi, v Argu. Vse se spreminja in nič ne premine. Ne, duša potuje, sem in tja hodi in tja in sem in v razna telesa, včasih v človeško telo iz živalskega, včasih obratno, res, nikdar ne umre, živi in ostane vse čase. Kakor predela v različne podobe se vosek gnetljivi, ne da ostal bi, kar bil je, zunanjosti pač ne ohrani, vendar pa v bistvu je isti, tako tudi duša po mojem vedno je ista, čeprav v različne prehaja oblike. Torej - požrešnost želodca nikar naj ne stre vam sočutja, prizanesite, svarim vas, sorodstvenim dušam, $\mathrm{z}$ umorom jih ne izganjajte strašnim in kri naj krvi ne uživa!

In ko po morju širokem že vozim se in sem na polno jadra vetrovom razpel - na vesoljnem ni svetu nič stalno. Vse se giblje in vse, gibajoč se, dobiva obliko.

Tudi sam čas se tako neprestano premika in teče, nič drugače kot reke. Ustaviti reke ne moreš 
niti ne ure begotne: valovi podijo valove, prihajajoči zaganja se v prejšnjega, vanj pa že drugi, časi enako bežijo, enako si vselej sledijo, novi in novi, kar prej je bilo, je za vselej minilo, česar bilo ni, nastaja in vsak se trenutek spreminja.

Vidiš, še noč, ko mineva, hiti, da preide v svetlobo, dneva bleščeči sijaj pa za črno nočjo se poganja. Da, še barva na nebu ni ista, ko trudno počiva vse v tišini, ko svetla Danica nam vzide na belcu, druga, ko spet Palantida, ta jarka predhodnica dneva, 190 svet, ki Fojbu potem prepustiti ga mora, obsveti. Ščit božanski še sam, ko zjutraj dviguje se z zemlje, rdeč je in zopet je rdeč, ko tone zvečer za gorovje, ko je najvišje, pa svetel je, eter je tamkaj čistejši, daleč odmaknjen od zemlje, dotikanja z njo se ogiba. Nočne Diane oblika pa tudi ni vedno enaka niti ne ista. Če raste, bo danes od jutrišnje manjša, hkrati pa večja, takrat ko pojema in krog si zožuje.

Dalje, ne veš, da v štirih razdobjih poteka nam leto, kot bi po zgledu življenja se našega vselej ravnalo?

Nežna in sočna je doba pomladna, otroški podobna, bilje tedaj je še mlado in nima moči, a bohotno, dasi še šibko, poganja in kmeta navdaja $\mathrm{z}$ veseljem. Vse že cveti in polje igra se s pisanim cvetjem, vendar v mladičju še vedno ni prave moči in odpora. Leto nato iz pomladi močnejše preide v poletje, krepek mladenič postane: močnejše je ni, bogatejše mimo te dobe je ni in je ni, ki bila bi bolj vroča. Potlej spet pride jesen, ko plamen mladostni ugaša, zrela in mila, po svoji umerjenosti že nekako $\mathrm{v}$ sredi med mladcem in starcem, že glava postaja ji siva. Potlej s tresočim korakom približa se zoprna zima, plešasta, če pa še kaj ji las je ostalo, so beli.

Naše telo se tudi nenehno in vedno spreminja, kar smo še včeraj bili ali zdaj smo, že jutri ne bomo. Doba bila je, ko v matere prve telesu kot seme vsi smo počivali, up smo bili človeškega roda. $Z$ veščim prijemom narava posegla je, ni si želela, tega, da v maternici nosečnice stiskalo skrito dlje bi telesce se, brž ga iz postelje te je rešila. 
Ko pa na svet je prišel, brez moči je otrok bil in ležal; kmalu nato kot žival je začel kobacati po štirih, sčasoma, ne še prav trden v nogah, je že stal in kolebal, shodil polagoma, ko ga je držal še kdo in podpiral. Potlej je, krepek in hiter, v mladeniško dobo prestopil, ko pa nato mu potekla še srednja so leta življenja, spustil navzdol se po strmi je poti nadležne starosti. Ta pa moči, ki jih toliko prejšnja je doba imela, zdaj spodkopava in ruši. Zato ostareli zdaj Milon vzdihne, ko mlahave roke pogleda, ki včasih imele mišice močne so, Herkulovim so bile že podobne. Vzdih Tindaridi uide, ko gleda kot starka v zrcalu gube si; zraven se vpraša, zakaj so jo dvakrat ukradli. Čas nenasitni in ti, osovražena starost, obadva vse pokončata, ker vse, kar kdaj načneta z zobovjem, drugo za drugim počasi pospravita s smrtjo brezčutno!

Ne, še ti niso stalni, ki pravimo jim elementi, ves čas se menjajo, kdor bo prisluhnil, sedaj poučim ga! Štiri osnovne prvine vsebuje ta svet, ki je večen: zemlja in voda sta dve izmed njih in sta težki ter s svojo težnostjo vedno tiščita navzdol, a drugi dve teže nimata in, ker ju nič ne teži, se poganjata kvišku to sta pa zrak in ogenj, od čistega zraka čistejši.

Dasi v prostoru so ločeni, vendarle hkrati nastaja vse iz njih in se vanje povrača: razkrojena zemlja zredči v tekočo se vodo, ki spet, izhlapela kot vlaga, v zrak se prevrže; ko teže potem iznebi se, preide v lege najvišje kot zrak najčistejši in vname se v ogenj. Potlej obratno godi se in v istem se redu obnavlja. Ogenj zgoščeni se v zrak že spet spreminja, iz tega voda nastane, a voda zgoščena strdi se spet v zemljo.

Nič posebnosti svoje več nima, narava prenavlja druge oblike iz drugih. Zato verjemite, v tem svetu, kakor je velik, nikoli nobena stvari ne izgine, zgolj spremeni se in preoblikuje. To torej pomeni: $\mathrm{z}$ rojstvom preprosto le drugo postaneš kot to, kar si prej bil, smrt pa se pravi prenehati biti, kar si. In ker ono semkaj, a to preneseno je tjakaj, v celoti vse traja.

Mislim, da nič ne ostane za trajno pod isto podobo. Zlata je doba tako se v železno prevrgla in tudi 
krajin usoda se tolikokrat je tako spremenila.

Sam sem videl; kar nekdaj bilo je najtrdnejše kopno, morje je zdaj, in videl sem zemljo, nastalo iz morja. Daleč od morja še školjke leže, a na gorah visokih našli so sidro prastaro; nekdanjo navadno ravnico voda pretvorila s svojim deročim je tokom v dolino, goro povodenj odnesla je v morje in tam, kjer močvara nekdaj bila je, zdaj suha in žejna puščava se širi, kar pa je žejo trpelo, poplavljeno je in močvirno. Tukaj narava je nove studence odprla, a tamkaj spet jih zaprla: iz notranjosti, ki potres jo zrahljal je, reke priderejo, včasih pa vanjo gredo, se zgubijo. Daleč od tam, kjer reko pogoltnila zemeljska poč je, Lik se na novo prikaže in teče iz drugega ustja. Prav tako ponikne in skozi ponore valeč se spet Erazin se mogočni razlije čez argoška polja. Tudi Kaiku tam v Misiji prejšnji izvir in bregovi, pravijo, niso pogodu bili, da dere drugod zdaj. Pesek sicilski s seboj Amenan zdaj odnaša, ko teče, včasih pa viri njegovi zaprejo se, žejen usiha.

Prej se Anigrova voda je pila, a zdaj se je noče več nihče dotakniti, odkar so dvoliki kentavri, pravijo pesniki, v njej si izpirali rane, zadane s Herkula puščico, sproženo tja s kijenoščevim lokom. Ali ni Hipan, ki v skitskem gorovju oddaljen izvira, sprva bil sladek, potem pa se z grenko soljo je pokvaril?

Nekdaj obdajali Faros, Antiso in Tir feničanski morski valovi so, danes pa nič več niso otoki.

Levkado, v času naseljencev starih še v stiku s celino, morje obliva zdaj. Zankla baje se je tudi držala nekdaj Italije, dokler med njima ni morje odneslo zemlje obmejne; pognalo je otok $\mathrm{z}$ valovi od kraja. Kdor bi Helik iskal in Buro, dve mesti ahajski, našel obe bi pod vodo; še danes ti radi mornarji kažejo mesti in hiše pogreznjene tam v globočini. Blizu Trojzene Pitejeve, tam, kjer nekoč se poljana širila ravna je, holm se dviguje, ves strm, neporasel. Silni vetrovi - težko je o tem že samo govoriti v temnih votlinah zaprti, na zrak so hoteli prodreti. Ko so zaman se borili, da mogli pod prosto nebo bi, kjer ni nobene v votlinah bilo odprtine, da skoznjo pihali bi, so napihnili zemljo, tako kot mehur se 
z dihom človeškim in s pihanjem ust lahko napihuje, prav kot dvorogega kozla odrtega meh se napihne. Tale vzboklina je kraju ostala in zdaj je podobna holmu visokemu, ki se je dolga stoletja ohranil.

Ker se še drugega mnogo spominjam, kar čul sem in videl, nekaj bom zdaj povedal. Kaj nima še voda tekoča raznih oblik? Ne dobiva še novih? Opoldne je mrzla, Amon rogati, ti voda, zvečer in pa zjutraj je topla.

O Atamancih se pripoveduje, da drva prižgejo $\mathrm{Z}$ vodo, ko mesec na nebu v najmanjši obseg svoj preide.

Reko imajo Kikonci, ki drob skameni, če jo piješ, predmet, ki pride $\mathrm{z}$ njo $\mathrm{v}$ stik, pa z marmorjem vsega prevleče.

Kratis in Sibaris, reki sosednji na naši ravnini, prav kot zlato ali jantar lase ti pobarvata $\mathrm{z}$ vodo. Kar je še bolj čudovito, so reke, ki ne le telesa, temveč ki duše ljudem z vodovjem lahko spremenijo.

Kdo še ni čul o Salmákidi z njenim zloveščim vodovjem, kdo ni o jezerih čul etiopskih? Kdor pije njih vodo, ali zbesni ali trdno in čudno objame ga spanje. Kdor iz klitorskega vira si kdaj bo žejo olajšal, vina se več ne dotakne, ves vzdržen je, pije le vodo; bodisi v vodi je moč, ki nasprotna je močnemu vinu, bodisi sin Amitáonov, kakor vedo domačini, ko obnorele je Projtide s čari in travami rešil besnosti, vrgel je v vodo čistilo, ki pamet zbistri ti, stud pa do vsakega vina ostal od takrat je v valovih. Tej po učinku nasprotna je voda iz reke Linkestij, kdor le nekoliko pije iz nje, pa četudi le zmerno, kleca in ziblje se, prav kot napil bi se čistega vina. Jezero najdeš v Arkadiji, stari so Fénej mu rekli, z dvojnato vodo je čudno sumljivo - ponoči se boj je: spita ponoči škoduje, podnevi jo piješ brez škode. Jezera razna in reke moči različne imajo. Bil je čas, ko Ortigija prosto je plavala v morju, danes miruje. In Argo se je ob razburkanem morju bala obeh Simplegad, ko valovje je treskalo vanju, zdaj se več ne premikata, trdni kljubujeta vetru. Etna, v kateri gorijo žveplene peči, tudi sama vedno ne bo ognjena, kot ni bila vselej ognjena. Bodisi zemlja je živa, kot bitje živi in na krajih mnogih preduhe ima, po katerih plamenoma diha. Vsakokrat, kadar se strese in zgane, pa te odprtine menjati more, zadelati tu in odpreti drugje jih; 
bodisi urni vetrovi, v najglobljih votlinah zaprti, mečejo skale ob skale, ob gmoto z vnetljivim semenom, ta pa, ko s silo trdo udari, se v ogenj razvname, potlej, ko veter preneha, votline kot prej so spet hladne; bodisi vnamejo spodaj plasti se smolnate v zemlji, žveplo rumeno se vžge, pri tem pa neznatno kadi se. Kajpada, kadar pa zemlja plamenu ne bo več dajala hrane maščobnih netiv, ko sčasoma šla bo zaloga, vse gorivo bo slednjič pošlo požrešni naravi, ogenj pa lačen zapustil bo te opustošene kraje.

V hiperborejski Paleni pa, kakor se pripoveduje, taki živijo ljudje, ki pokrije telesa jim perje, kadar devetkrat telo jim Tritonije jezero zmoči. Tega sicer ne verjamem - a isto sem slišal za Skitke, bojda počnejo enako, ko s strupom telo oškropijo.

Če pa se količkaj sme verjeti preskušenim dejstvom, ali ne vidiš, da vsako telo, ki polagoma shira, ko mu poide toplota, pretvori se $\mathrm{v}$ majhne živali? $\mathrm{V}$ jamo zakoplji boginjine vole zaklane, iz droba njihovega, ko segnije, kot veš, se rodijo čebele, cvetje obirajo blizu in daleč; po prednikov zgledu ljubijo polje, se trudijo delavne, $\mathrm{z}$ upom na boljše. Iz zakopanega bojnega konja sršen se rodil bo. Kadar obalnemu raku odvzameš uvite ščipalke, drugo pa v zemljo zagrebeš, iz tja zakopanega dela kmalu škorpijon se izmotal bo, z repom zavihanim žugal. Poljske gosenice, ki se zapredajo redno na listje s svojimi sivimi nitmi, kot dobro vedo kmetovalci, novo zunanjost dobe, kot metulji v okras so grobovom.

V blatu so klice, iz njih se zelene razvijejo žabe, najprej brez nog, a jih kmalu dobijo; da s svojimi kraki zmorejo plavati, zraven pa daleč na suhem skočiti, zadnji teh krakov so bistveno daljši kot sprednja dvojica. Tudi mladič, ki povrže medvedka ga, sprva ni drugo, kakor le živo meso, a ko stara ga liže, izliže ude in tudi obliko mu takšno, kot sama ima jo. Ali ne vidiš, da zarod čebel medonosnih, ki skrit je v celicah šesterokotnih iz voska, brez udov rodi se, noge dobi pa pozneje in pozno dobi tudi krila? Ptica Junonina z zvezdnatim repom in Jupitrov orel, strelonosilec, Kiterkin golob in kar je še ptičev kdo bi si mislil, če ne bi že vedel, da iz rumenjaka 
v jajcu izleči se morejo? - Kadar pa v grobu zasutem gnijejo v zemlji kosti, v hrbtenici, kot mislijo, mozeg $\mathrm{v}$ kačo lahko spremeni se. A vendar izvor in nastanek morejo vse te živali iz drugih le bitij imeti, razen edinstvene ptice, Asirci ji pravijo feniks: ta tako se obnavlja, da sama iz sebe rodi se. Zrnja ne je in ne mara zelišč, le smolovca solze s sokom balzama rede jo. Ko pet stoletij dopolni, sama si v krošnji iz vej na vrhu tresoče se palme s kremplji in s kljunom gnezdišče napravi, v katerega vplete trave dišeče in nardovo mehko latjé in po vsem še miro zdrobljeno in cimet rumenkastorjavi potrese, nanj se uleže in v samih vonjavah preneha živeti. Potlej, kot pravijo, spet iz telesa se starega mladi feniks rodi, ki spet bo toliko časa preživel.

$\mathrm{S}$ časom, ko moč pridobi, da bi breme že mogel nositi, z vej drevesa visokega težko gnezdišče odvzame, zibelko svojo in starega grobnico v vdani ljubezni nese skoz lahko ozračje tja v Hiperiónovo mesto, kjer odloži ga pred svetimi vrati njegovega templja.

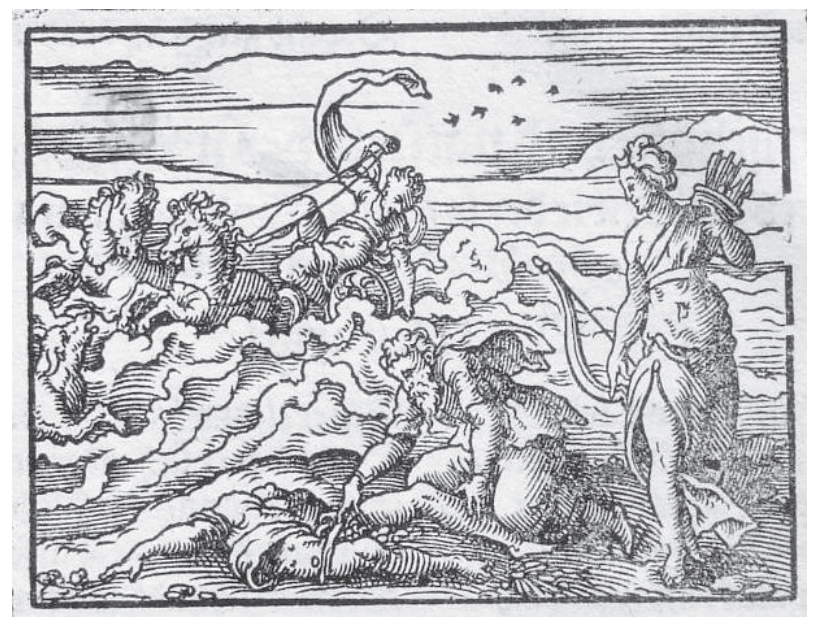

Slika 33: Phoenix ales (15.391-407)

Toda če to nenavadno je čudno, kako se čuditi zopet hijeni je; ta kot samica je pravkar na hrbtu samca imela, sedaj pa, prečudno, že sama je samec.

Druga žival, ki hrani z vetrovi samo se in z zrakom, kakršnekoli se barve dotakne, brž sama dobi jo. $\mathrm{V}$ trto odetemu Bakhu premagana Indija dala 
rise je; tem pa, kot pravijo, vse, kar curi iz mehurja, kamen pri priči postane, zato, ker strdi se na zraku. Tudi korale, ki v morju pod vodo so mehke rastline, okamenijo takoj, ko v stiku se znajdejo z zrakom.

Dan bi minil in upehane konje že Fojb bi okopal v morju globokem, še preden bi vse omeniti utegnil, kar se je kdaj preobličilo. Vemo, da vse se spreminja, narodi tudi tako nekateri so močni postali, drugi propadli. Tako se je Troja, bogata in močna, vse desetletje borila, prelivala kri je obilno, danes neznatna samo ruševine starinske še kaže, kaže namesto bogastva samo še grobove pradedov. Slavna je Sparta bila in mogočne bile so Mikene, prav tako mesto Kekropovo in zraven Amfiona mesto. Sparta neznaten je kraj zdaj, Mikene ponosne so padle; niso nemara kot pravljica zgolj Ojdipove Tebe?

Kaj Pandionovim razen imena ostane Atenam?

Rim zdaj dardanski, kot pravijo, vstaja, ki temelj na novo tamkaj ob Tiberi, reki, ki teče izpod Apeninov, zgradbi ogromni za svoje prihodnje gospostvo polaga. Tudi ta raste, se hitro spreminja in glavno bo mesto kmalu sveta neizmernega. Vidci, preroški izreki, kakor se pravi, so to napovedali. Kolikor pomnim, ko se je Troja majala in dvomil Enej je v rešitev, Helen je, Priamov sin, jokajočemu tole govoril: "Sin boginjin, če moje prerokbe še kaj se spominjaš, Troja ne bo docela propadla, ko ti se boš rešil.

Ogenj in meč ti pokažeta pot, da boš šel in boš s sabo Pergam ugrabljeni nesel, dokler ne boš sebi in Troji tuje dežele, prijazne še bolj od domače, dosegel. Vidim pa tudi že mesto, ki frigijski vnuk ga zgradil bo, takšnega ni in ne bo ga in videla ni ga preteklost. Razni vladarji ga v dolgih stoletjih napravijo močno, za gospodarja sveta pa tvojega Jula potomec.

Ko se bo z njim okoristila zemlja, ga etrski dom bo vase sprejel in imel ga, ker konec njegov bo na nebu.« To, kot spominjam se, Helen nosilcu penatov Eneju prerokoval je in jaz veselim se, da rodno mi mesto raste; tako je koristila Frigijcem zmaga Pelazgov.

A da predaleč ne krenemo s pota kot konji, ki k cilju dirjati včasih pozabijo: vse nebo in pod njim vse, 
zemlja in vse, kar na njej je in v njej, spreminja obliko.

Mi pa, vesoljnosti delec, ki nismo samo iz telesa, temveč imamo še dušo selivko, smo zmožni preiti $\mathrm{v}$ divje živali in tudi v drobnico se moremo skriti. Torej živali, ki staršev imeti utegnejo duše bodisi bratov in drugih sorodnikov, bodisi kakšnih drugih ljudi, pustimo spoštljivo pri miru, da ne bi s hrano Tiestovo sami si svojih želodcev polnili! Kruto na to se privaja, brezsrčno se zraven pripravlja kri človeško preliti, kdor vrat teletu prereže, ne da pri tem bi ušesa mu mukanje bridko ganilo, vsak, kdor zmore zadaviti jagnje, ki veka kot dete, vsak, kdor s ptico se zmore hraniti, ki sam jo vzredil je! Koliko neki še manjka pri teh do pravih zločinov, kam vse še pot jih od takih dejanj pozneje pripelje? Vol naj orje in čaka naj svojega konca s starostjo, ovca naj s svojo nas volno varuje pred zimo ledeno, koze naj site nam nudijo vime za molžo z rokami. Mreže, pasti in zanke ter druge zvijačne nastave vse odstranite, naj limanic vaba ne vara več ptičev. Tudi jelenov s strašili iz perja nikar ne plašite, niti ne skrivajte $\mathrm{z}$ vabo varljivo ukrivljenih trnkov. Kar je škodljivo, uničite; tega potem ne pojejte, več ne jejte mesa, preživljajte z lahko se hrano!«

\section{Egerija in Hipolit}

S temi in $\mathrm{z}$ drugimi nauki tako poučen se je vrnil Numa domov, kakor pravijo; tam je nad latijskim ljudstvom vlado prevzel, ko ga samo od sebe za to je prosilo. Srečen je z ženo bil, nimfo, poslušal je umno Kamene, svete obrede uvedel in narod, ki divjih je bojev vajen bil, v miru izučil je v raznih obrtnih veščinah. V letu, ko star kraljevanje je hkrati z življenjem odložil, Numovo smrt je latijsko ljudstvo, visoko in nizko, objokovalo, a žena njegova odšla je iz mesta, skrit se je šla v dolino Arikije, v goste gozdove, kjer orestejski Diani motila je svete obrede z jokom in s tarnanjem. Kolikokrat so iz gajev in jezer nimfe svarile jo, naj ne žaluje, jo tam tolažile! Kolikokrat ji Tezejev je sin, ko je jokala, rekel: »Daj, pomiri se, nehaj, saj nisi edina nesrečna, 
glej na podobne primere nesreče pri drugih in lažje svojo prenašala boš! Da moj zgled bi bil manj uporaben, to si želim - pa vendarle z njim te morda potolažim.

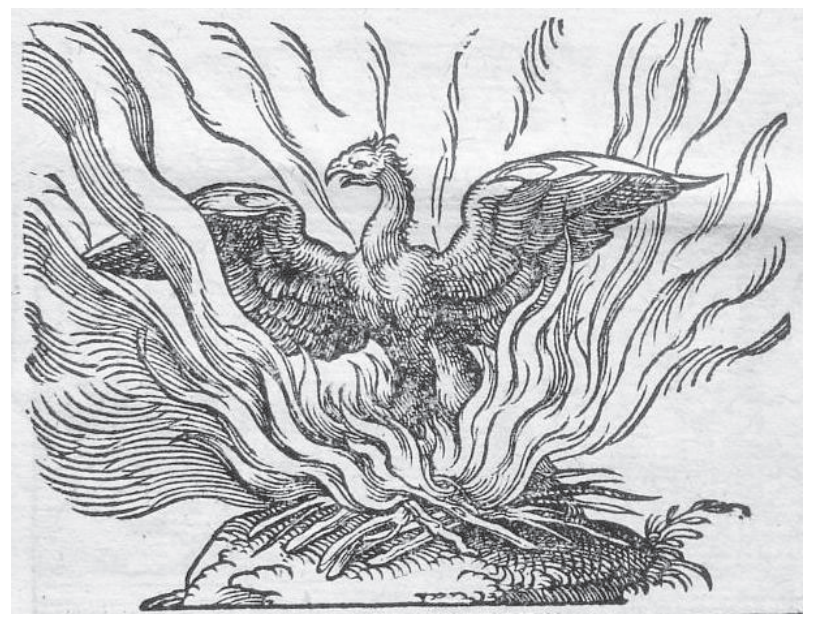

Slika 34: Hippolytus auriga (15.496-546)

Najbrž si slišala praviti kdaj, da živel je Hipolit; sam lahkoverni mu oče s prevaro je mačehe hude vzel življenje - čudila se boš in boš komaj verjela: to sem jaz. In hči Pasifajina, mačeha, nekdaj

z mano zaman je hotela oskruniti možu ležišče, potlej pa, kar je hotela, nesrečna je name zvrnila. (Jezna, ker sam sem zavrnil jo? V strahu pred mojo ovadbo?) S takšno obtožbo me oče nedolžnega brž je iz mesta spodil in glavo v sovraštvu preklel mi, ko proč sem odhajal. Bežal na vozu sem proti Trojzeni Pitejevi, toda brž ko obalo Korintskega morja dosegel sem, morje $\mathrm{v}$ breg je planilo in silno valovje kot gora je zraslo, bočilo se in bučalo, nato pa se v vrhu razklalo. Izmed valovja razklanega bik se rogati je dvignil, v zraku privzdignjen pokonci do prsi je vztrajal nad vodo, morje pri tem iz nozdrvi in žrela mu besno je vrelo. Mojemu spremstvu pogum je upadel, a jaz, še zamišljen v svoje izgnanstvo, se nisem ustrašil. Tedaj obrnili $\mathrm{k}$ morju so glave mi konji vihravi in strigli $\mathrm{z}$ ušesi, strah pred neznansko pošastjo jih zbegal je, že so zdrveli $z$ vozom po skalni strmini. Sam belo openjene brzde skušal zaman sem z roko ravnati, čeprav sem se hitro nagnil nazaj in vajeti voljne na vso moč napenjal. 
Moje moči pa ne bi preplašenih konj zadržale, ne, če se ne bi kolo, kjer os ga drži nepremična, spotoma strlo ob štoru, na kosce se vse razletelo. Vrglo tedaj me z voza je; ker sam zapleten sem bil v uzde, te pa navite na štor, telo se je vse raztegnilo, nekaj se udov je strgalo, zvezani drugi bili so, glasno so pokale in se lomile kosti mi, še dušo videla bi oditi utrujeno, več na telesu enega uda bilo ni, ki kdo bi lahko prepoznal ga, drugega več na njem ni bilo kot rana pri rani. Ali ob tem bi upala si in bi mogla, o nimfa, svojo nesrečo primerjati z mojo? Saj videl sem tudi kraje, ki nimajo dneva, in tam v Flegetontovi vodi grel sem telo razmesarjeno. Ne bi bil živ, če me ne bi sam Apolonov sin z mogočnim zdravilom ozdravil. Ko ob pomoči Pajónovi močna zelišča so dala spet mi življenje kljub Ditu, me v goste oblake je skrila Kintija, češ da oživljen in viden zavist bi povzročal. Da bi bil varen in videti dal bi lahko se, dodala nekaj je let mi in ves je obraz mi zato spremenila v neprepoznavnost. Tehtala dolgo je, ali naj Kreto ali naj Delos mi da za dom. Ko je le opustila Delos in Kreto, me sem je postavila; zraven sem moral menjati svoje ime, ki na konje spominjalo prej je. »Ti, ki doslej si Hipolit bil, « rekla je, »bodi zdaj Virbij!« Tukaj v tem gaju odslej prebivam kot nižje božanstvo, v varstvu boginje deviške in $\mathrm{k}$ njenim tako se prištevam. «

Vendar Egeriji tuja nesreča ni žalosti njene mogla olajšati, tam ob vznožju je gorskem ležala, solze prelivala, dokler trpeče ni Fojbova sestra slednjič usmilila se in je tam spremenila v studenec, udov pa stanjšala v večno se prelivajoče valove.

\section{Tag, Romulovo kopje, Kip}

Nimfe novica o tem je ganila in sin Amazonkin čudil tako se je kakor tirenski orač, ko na njivi videl usodno je grudo, ki sama od sebe se sprva gibala je, a potem izgubila obliko prsteno, človek postala, ki usta takoj je odprl v prerokbe. Tag so mu dali ime domačini, on prvi Etruske 
sam je učil preroško zagledati motno prihodnost; ali kot Romul, ko videl je kopje, ki se zasadilo v grič palatinski je in je začelo poganjati liste, zakoreninjeno v zemlji in ne več stoječe na osti, nič več orožje bilo ni, postalo drevo je in senco občudovalcem dajalo nenadno je $\mathrm{z}$ gibkim vejevjem; ali kot Kip, ko zrcalila voda ga $\mathrm{v}$ reki z rogmi je. Videl se je in misleč, da podoba ga vara, si s prsti šel je prek čela in to, kar je videl, otipal. Obstal je (vračal takrat se je ves zmagovit po porazu sovraga) ne da oči bi kaj grajal, jih vzdignil je hkrati z rokami k nebu, rekoč: »Naj karkoli pomeni to znamenje, višnji, če je veselo, za dom naj bo, za Kvirinovo ljudstvo, če pa je slabo, le zame! « Nato iz zelene je ruše zgradil oltar in na njem žrtvoval v odišavljenem ognju, vina iz žrtvenih skledic je zlil in drhteče drobovje dal preiskati zaklanih ovac, če kaj napove mu. Ko ga tirenski je vedeževalec pregledal, v drobovju videl je velik državni prevrat, a še nič kaj razločno. Potlej, ko sam je dvignil oči od drobovja pri ovci, ostro roge je pogledal na Kipu in tole mu rekel: »Bodi pozdravljen, o kralj! Ta pokrajina namreč z gradovi Latija tebi, moj Kip, in rogovom bo tvojim podložna.

Nič ne čakaj, pohiti, da skozi odprta boš vrata vstopil. Tako ukazuje usoda. Ko sprejme te mesto, kralj boš, ker prav zagotovo dobil vekovito boš žezlo.« Kip se nato je umaknil in z mračnim obrazom od mesta svoje obrnil oči ter rekel: »Bogovi, kam daleč, daleč kam spravite tole prerokbo! Saj mnogo srečnejši živel kjerkoli v pregnanstvu bom kakor pa vrh Kapitola, če bi me kdaj tam gori resnično kdo videl kot kralja." To je dejal, nato pa hitro s senatorji ljudstvo sklical, potem ko poprej z lovoriko miru si rogove svoje zakril je. Nato na nasip, ki so tam ogradili hrabri vojaki ga, stopil je, najprej po šegi pomolil k starim bogovom in rekel: »Nekdo je med vami, ki kralj bo, če ga takoj ne boste izgnali iz svojega mesta.

Kdo? Ne bom ga navedel $\mathrm{z}$ imenom, le znamenje dam vam: par rogov na čelu ima. Zanj vedež je rekel: Rim bo zasužnjil, če kdaj tu v mestu bo vašem se znašel. Zdaj že lahko skozi vrata odprta lahko bi prodrl, sam pa sem to mu preprečil, čeprav mi bližji od njega ni nihče. Kviriti, vi tega moža prepodite, 
ali če to bi zaslužil, vklenite ga v težke verige, ali pa strah preženite in smrt zadajte tiranu!« Kakor valovi hrumijo, ko kdo jih od daleč posluša, ali kot smreke visoke šumijo, če vzhodnik predrzni vanje zapiha, tako je takrat završalo med ljudstvom. Vendar med vikom in krikom razgibanih množic na zboru slišal močno izmed vseh le en glas se je: »Kdo je ta človek? « Vsi so po čelih si gledali, vsi so iskali rogove. »Tu ga imate, ki iščete ga, «je spet Kip spregovoril, z glave, čeprav mu je ljudstvo branilo, snel venec in hkrati čelo pokazal visoko, na njem pa dvojna rogova. Vsi odmaknili oči so in vsi so naglas zaječali; kdo naj bi temu verjel, kar vsem so oči govorile? Eden za drugim neradi so gledali glavo zaslužno. Da bi pa dlje brez časti ne ostala, so slavnostni venec nanjo že spet položili, veljaki, ker smel ni več v mesto, so počastili te, Kip, in dali ti toliko zemlje, kolikor z voli bi vpreženimi oborati jo mogel, kadar zarana bi lemež zastavil in nehal z večerom. Potlej so vrezali v bronast podboj te čudne rogove tam pri vratih, da vsem bi ostali še dolgo v spominu.

\section{Ajskulapij}

Zdaj pa povejte še, muze, ob pesnikih vedno navzoče, (ve to veste, ne moti pri tem vas davna preteklost), kdaj na otok, ki Tibera s svojo ga vodo obliva, mesto je Romulovo Koronida dobilo v svetišče.

V Latiju grozna je kuga nekoč zasmradila ozračje, shujšana bleda telesa pokrivali gnojni so tvori. Vsi od pogrebov utrujeni videli so, da ne more biti v korist ne človeška izkušnja ne znanje zdravnikov, božjo pomoč so iskali in k Fojbu so šli v preročišče, daleč tja v Delfe, ki s svojim ozemljem na sredi sveta so, tam so prosili, da v hudih bi jim pomagali težavah $s$ kakšnim nasvetom in tolikšno mesto rešili nesreče. Prostor in lovor in tok, ki imel ju je bog na podobi, stresli so hkrati se, tam iz notranjosti vse nedostopne glas se je slišal s trinožnika, srca vsa plaha je ganil: »To, kar iščeš, Rimljan, bi v kraju, ki bližji je, našel, išči zato zdaj bližje: če hočeš olajšati stisko, 
ni ti treba Apolona, sina njegovega najdi!

Srečno hodite in čimprej poiščite mojega sina!« -

Umni senat, ko so to naročilo boga mu prinesli,

najprej je kraj poiskal, kjer Fojbov naj sin bi prebival, potlej pa sle $\mathrm{k}$ Epidavra obali je z ladjo napotil.

Brž ko sli v trebušasti ladji do tja so prispeli, v zbor med grške veljake so šli in tam jih prosili, naj jim dajo boga, ki bi s svojo navzočnostjo rešil ljudstvo Avzonije kuge morilske po božjem izreku. Mnenja veljakov ločila so se in bila so različna: eni tako so sodili, da ni pomoči jim odreči, drugi drugače so rekli, da svoje opore ne dajo, vse obdržijo naj zase in ne izročijo božanstva.

V tem, ko tako so razpravljali, mrak se je spustil na zemljo, noč razprostrla temo nad vesoljno je zemeljsko oblo, v snu pa se tebi, Rimljan, je pred posteljo tvojo prikazal bog, ki prinaša pomoč, a le takšen, kot vidiš ga v templju: držal je v levi gorjačo, a $\mathrm{z}$ desno si gladil je brado, te so besede mu vrele iz prsi: »Ne boj se, prišel bom, vendar pa tole podobo bom svojo poprej si spremenil. Kačo to zdajle poglej, ki palico mojo ovija, dobro jo glej, tako, da jo mogel boš spet prepoznati. Vanjo se bom spremenil, a večji bom, toliko velik, kolikor moje božansko telo si zasluži veljave." Hipoma z glasom izginil je bog, a za glasom in bogom šel tudi sen je in dan za pobeglim se snom je zazoril. Zjutraj, ko zarja je vzšla in zvezde bleščeče pregnala, $\mathrm{v}$ tempelj prelepi boga iskanega šli so veljaki, brez odločitve, kako naj ukrenejo. Tam so prosili; z znamenjem bog naj božanskim pove, kje hoče živeti. Komaj so dobro končali, ko v kači z visokim grebenom vse nenadno je s sikanjem zlati jim bog napovedal. S svojim prihodom je zganil svoj kip in oltar in pa vrata, prav tako marmorna tla in zraven še zlato pročelje. Sredi svetišča obstal je in vzpel se do prsi visoko, gledal okrog je z ognjenim pogledom, kar vse je pretreslo. Žrec, ki lase posvečene imel je povezane s trakom, (trak je bil bel), je božanstvo spoznal in takole je rekel: »Glejte, poglejte boga! Kar vas tukaj je, v sveti tišini zbrani bodite! Prelepi, ki zdaj si se tu nam prikazal, bodi nam dober in ljudstvu, ki tu te časti, zdaj pomagaj!« Vsi so brž počastili boga in zraven za žrecem vsi ponovili njegovo so prošnjo; Enejevci sami 
s svetim so molkom in zbrani in s prošnjo mu čast izkazali.

Njim je prikimal, obljubil pomoč, ko nenadoma zganil greben je svoj in spet z jezljajočim jezikom zasikal. Potlej po svetlih stopnicah se vil je in glavo obrnil, odhajajoč je na stari oltar še enkrat pogledal, hkrati pa dom, ki ga vajen je bil, in svetišče pozdravil.

Dalje po tleh se je, s cvetjem na gosto posutih, poganjal silni kačon valovito naravnost po sredi skoz mesto proti pristanu, ki bil je zaščiten $\mathrm{z}$ vzboklim nasipom.

Tam se ustavil je, kot bi od svojih se v množičnem spremstvu hotel dobrotno s prijaznim obrazom tedaj posloviti, potlej na ladjo avzonsko se vzpel je, se vanjo zavalil. Ta občutila božanski je tovor in globje pod težo božjo je v vodo zaplula. Veseli Enejevci zdaj so vola zaklali, ovenčali ladjo in dvignili sidro. Sapica lahka pognala je ladjo: visoko iz nje je dvigal se bog, na ukrivljeni krn je glavo položil, razgledujoč se po sinji gladini. Prek Jonskega morja vel je ugoden zefir; ko šestič je vzšla Palantida, ladja prišla je v Italijo, šla ob lakinijskem templju, ob skialejski obali in mimo Japigije, dalje z levimi vesli amfrisijskih se izognila čeri je, $\mathrm{z}$ desne kalenskih strmin, ko je mimo Rometija plula, mimo Kavlona, Narikije, preko morja in ožine tam pri sicilskem Peloru, od koder je spet zapeljala proti Ajolovim dvorom in rudnikom mesta Temese, proti Levkosiji, k toplega Pajsta cvetličnim vrtovom. Mimo Kapreje, predgorja Minervinega in pa gričev, kjer plemenita sorentska vinika uspeva, in mesta Herkulovega in Stabij in zgolj za brezdelje nastale Partenopeje vozili so k templju kumajske Sibile. Proti Liternu, kjer topli so vrelci in raste mastika, dalje od tam so krenili in proti Volturnu, ki s sabo pesek vali, k Sinuesi, ki polna je belih golobov, proti nezdravi Niturni in tja, kjer rejenec pokopal svojo dojiljo je, v kraj Antifátov, v Trahanto močvirno, dalje še h Kirkini zemlji in k Antija ozki obali. Morje bilo je viharno, ko z ladjo so svojo mornarji tamkaj pristali; tedaj pa zviti se bog je odmotal, vil valovito v velikih vijugah se je in izginil $\mathrm{v}$ tempelj očetov, ki dvigal se je ob rumeni obali. Morje takoj se spet pomiri; Epidavrijec pustil spet je očetov oltar in v varstvu njegovem po bregu 
brazdil, ko vlekel prek peska šumeče luskinasti trup je.

Vzpel se je spet po krmilu na ladjo, na krnu visokem

z glavo slonel je, dokler pripeljali se niso do Kastra

in do Lavinija, svetega mesta, do Tibere ustja.

Tja od povsod pridrvela je množica ljudstva naproti,

ženske in moški, še te, ki ogenj tvoj, Vesta trojanska,

hranijo; vsi so boga slavili z veselim pozdravom.

Koder po reki nasproti tekoči je plavala ladja, tam na oltarjih, ki so na obeh se bregovih vrstili, žgali kadilo so prasketajoče in $\mathrm{z}$ dimom dišečim zrak prepojili, že žrtve zaklane ogrele so nože.

Brž ko je ladja priplula v prestolnico, v mesto Rimljanov, kača se vzpela je, vrat naslonila najviše na jambor, kjer se obračala je in iskala si kraj je primeren. Tam, kjer se reka razcepi na dvoje, kjer Otok obdaja, kot imenuje se svet, ki na sredi obeh je rokavov, reka $\mathrm{z}$ obeh strani enako ga $\mathrm{z}$ roko objema: tja zatekla se z latijske ladje je Fojbova kača, zopet prevzela je svojo prvotno božansko podobo, kugo pregnala je proč in mesto pogube rešila.

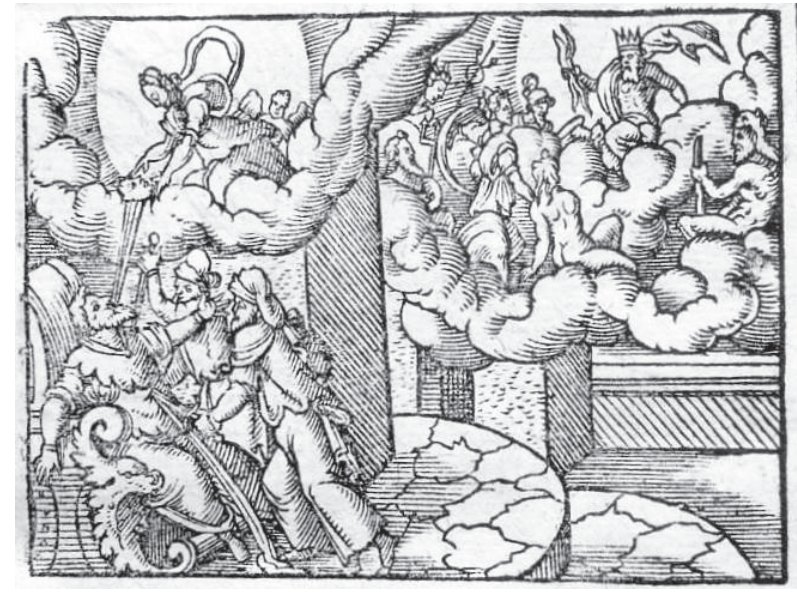

Slika 35: Caedes Caesaris (15.745-812)

\section{Apoteoza Julija Cezarja}

Vendar medtem ko ta bog kot prišlek se znašel je v mestu, Cezar na svojem je bog. Odličnega v boju in v miru niso ga toliko bitke s triumfi, ne dela mirovna niti ne slava, ki sam jo je hitro v državi pridobil, 
vpletle v ozvezdja na nebu kot nov komet, repatico, kakor pa sin njegov. Od vsega, kar Cezar je storil, večjega dela ga ni, kot da njemu je bil za očeta. Naj bi veljalo za več, da ukrotil je morske Britance, vodil po Nilu sedmerorokavnem, kjer pápir uspeva, ladje po zmagi, da zraven Numidijce vedno uporne, Juba kinifskega, Pont, ki ponašal se je z Mitridatom, spravil pod vlado Kviritov je, zraven še to, da triumfov mnogo zaslužil je, a jih imel je le nekaj - naj vse to več bilo bi od tega, da dal nam je takšno osebnost? Tak vladar je človeštvu res milosten dar, o bogovi! Da pa človeškega ta bi rodu ne bil, oni postati moral je bog. Ko vse to Enejeva zlata je mati videla, v tem pa spoznala, da pontifeks kmalu bo žrtev žalostne smrti z orožjem v zaroti, je vsa prebledela, vsakemu bogu ob vsakem je srečanju to govorila: »S kakšno zahrbtnostjo, glej, in nakano se spravljajo nadme, kakšna izdaja preti potomcu mogočne rodbine, njemu, ki zdaj mi edini ostal je po Julu dardanskem. Ali naj vedno in redno s skrbmi jaz sama se mučim? Najprej Tididovo me kalidonsko je kopje ranilo; vsa sem potrta bila, ker se Troja slabo je branila; potlej sem gledala sina, ki dolgo je blodil po morju, val ga je valu podajal, ga videla iti v podzemlje; s Turnom nato se je bil, no, bolje rečeno, z Junono. Toda kaj svojega roda nesreč se starih spominjam?

Prejšnjih težav se spominjati strah mi sedaj ne dopušča. Vidite, meči zločinski se spet proti meni ostrijo. Prosim, naj kdo jih ustavi, prepreči umor grozoviti; kdor svečenika ubije, bo Vesti ognjišče pogasil!«

Vendar zaman zaskrbljena je Venera to govorila vsem nebeščanom. Ganila jih je, a preprečiti niso mogli železnega sklepa prastarih treh sester usodovk, pač pa nedvomna so znamenja dali o bližnji nesreči. Žvenketajoče orožje se čulo je v črnih oblakih, grozne trobente oglašale dol se $\mathrm{z}$ neba so $\mathrm{z}$ rogovi, vse je zločin oznanjalo; mrka podoba je sonca zemlji vznemirjeni bledorumeno dajala svetlobo. Večkrat med zvezdami videli mnogi goreče so bakle, večkrat takrat med dežjem krvave so padale kaplje, svetli Danici obraz njen je črna pokrivala rja, 
kri oškropila je Luni kolesje in Stiksova sova

hudo nesrečo na tisoč je krajih obetala ljudstvu, kipi so slonokoščeni na tisoč se krajih solzili, v svetlih so gajih grozeči glasovi se čuli in petje. Žrtev nobena ni sreče obetala, drob je obljubljal velik upor, v želodcu so našli odsekano glavo. Pravijo tudi, da psi so ponoči na trgu pred templji lajali in okrog hiš; da so sence umrlih blodile, mesto pa vse se je zibalo v sunkih nenadnih potresa. Toda zahrbtnosti in bližajoče se usode bogovi niso z napovedmi svojimi mogli nikakor zatreti: z golimi meči zarotniki v zbornico šli so, v vsem mestu ni se noben drug kraj jim zdel za umor bolj posrečen. Bila tedaj si Kiterka $\mathrm{z}$ obema rokama je prsi, skriti hotela z oblakom je dediča sina Eneja, s takšnim, v katerem Atridu ugrabljeni Paris je zbežal, s takšnim, v katerem Eneja je meč Diomedov spregledal. Oče pa to ji je rekel: »Usodo nikdar spremenljivo sama poskušaš, o hči, ukloniti? Kar pojdi in stopi $\mathrm{v}$ dom treh sester, kjer videla boš v ogromnem prostoru $\mathrm{v}$ trdem železu in bronu zapiske dogajanj, ki sami niti zrušitve neba niti jeze se strel ne bojijo niti ne drugih udarcev, saj varni pred vsem so in večni. Tam boš, vrezano v neuničljivo kovino, usodo svojega našla rodu. Jaz sam sem jo bral, si zapomnil, zdaj ti povem, da boš vedela, kaj ti prinaša prihodnost. Ta, ki zdaj zanj, Kiterka, se trudiš, svoj čas je dopolnil, saj so minila mu leta, ko moral je biti na zemlji.

Da pa kot bog bo prišel v nebo in bo v tempelj postavljen, ti dosežeš in sin njegov, ki kot dedič imena nosil edini bo breme za njim; ko sam maščeval bo smrt očetovo, $v$ bojih še mene imel bo ob strani. Mutina, mesto oblegano, slednjič za mir bo prosila, Farsal z okolico svojo njegovo oblast bo začutil, v krvi ematijsko mesto Filipi bo plavalo v klanju, $\mathrm{v}$ vodah sicilskih mogočno ime bo za vedno zatrto, rimskega vojvode žena egiptovska, v svojo poroko vse preveč prepričana, padla bo, prej pa grozila, češ, Kapitol bo nekoč še njenemu služil Kanopu. Kaj naj barbare ti, ljudstva z obeh strani Okeana dalje naštevam? Kjerkoli je kaj obljudene zemlje, vsa bo njegova in sleherno morje bo njemu služilo. 
Svetu bo končno dal mir in posvetil se skupni blaginji, najbolj pravične zakone dajal bo in s svojim bo zgledom $\mathrm{k}$ dobremu druge usmerjal, ker sam na prihodnost bo mislil, mislil na čas, ki prihaja, na množico svojih potomcev; s takšnim namenom ukazal bo sinu prevzvišene žene dati po sebi ime in dati vladarske mu posle. Kadar nekoč v visoki starosti dopolnil bo leta, $\mathrm{v}$ etru dobil bivališče bo svoje ob zvezdi sorodni. Ti iz telesa, medtem umorjenega, dušo si vzemi, zvezdo ustvari iz nje, da moj Kapitol in z njim forum 840 večno $\mathrm{z}$ oboka visokega gledal bo Julij božanski.«

Komaj je to izgovoril, že sredi senata je stala Venera blaga in, ne da bi videl jo kdo, iz telesa svojega Cezarja dušo še svežo si vzela, da ne bi v zraku razšla se, ter nesla s seboj na nebo jo med zvezde. Nese jo, vmes pa začuti, da vsa se je vnela, da sveti; brž jo spusti iz naročja. Zdaj više od lune kot zvezda duša bleščeča se giblje in vleče za sabo na poti svoje ognjene lase - in ko sinove vidi zasluge večje od svojih, se kar veseli, da jo sin je prekosil. Dasi je ta prepovedal, njegovo bolj ceniti delo kakor očetovo, vendar kljub temu neustrašeno ljudstvo njemu je dajalo prednost in $\mathrm{v}$ tem mu je zgolj kljubovalo. Časti tako Agamemnonovi se Atrej je umaknil, v tem je Ajgeja premagal Tezej, Ahil pa Peleja. Končno, če zgled, ki podoben je njima, še zadnji navedem tudi Saturn je manjši od Jupitra. Jupiter vlada $\mathrm{v}$ dvorih nebesnih in hkrati še v trojnem kraljestvu vesolja, zemlji pa vlada Avgust, in vsak je vladar in pa oče.

Vas, bogovi Enejevi, prosim, ki meč ste in ogenj sami premagali, vas, bogovi domači, in tebe prosim, Kvirin, ki si mesto pozidal; Gradiv, tudi tebe, oče njegov, ter tebe, o Vesta, ki poleg penatov Cezarjevih te častijo, in tebe, Fojb dóma, s to Vesto, tebe, o Jupiter vzvišeni, zgoraj v tarpejskem svetišču, z vsemi bogovi, ki sme jih, ki prav je, da pesnik jih kliče.

Pozno naj pride ta dan, pozneje od moje starosti, dan, ko slovo bo vzel Avgust od sveta, ki mu vlada, sam pa se dvignil $\mathrm{v}$ nebo in od tam bo prosečim naklonjen. 
Epilog

Delo sem zdaj dokončal, ki ne Jupitrov srd in ne ogenj niti železo ne starost požrešna ga več ne uniči. Kadar pa dan bo prišel, ki pravico ima do telesa samega, dan, ki končal bo neznano dolžino življenja, boljši moj del se za večno bo dvignil visoko nad zvezde, moje ime bo ostalo in več ga nihče ne izbriše.

Koder se širi po zemlji podjarmljeni rimsko gospostvo, brali me bodo ljudje; če je količkaj res, da ne vara pesniška slutnja, na veke vse čase slovel bom in živel. 